\title{
EL MUNDO MUSICAL BIZANTINO A TRAVÉS DE LA MIRADA DE LOS ARTISTAS PLÁSTICOS
}

\author{
Rosario Álvarez Martínez \\ Universidad de La Laguna
}

\section{Resumen}

\begin{abstract}
Amplia panorámica de las imágenes musicales del arte bizantino, haciendo hincapié en las distintas temáticas donde aparecen, ya sean del ámbito religioso o del profano. Este recorrido nos ha permitido comprobar que, pese a la escasez de testimonios visuales que presentan sus manifestaciones artísticas debido a cuestiones doctrinales que también analizamos aquí, lo conservado nos muestra dos parcelas importantes de su mundo musical como son los instrumentos y la danza en muchas de sus ricas y variadas facetas. A través de todas estas imágenes se ha comprobado que Bizancio constituyó un crisol de culturas a lo largo de sus diez siglos de historia.
\end{abstract}

Palabras clave: Bizancio, iconografía, música, instrumentos, danza, arte, miniaturas, códices.

\section{THE MUSICAL WORLD OF BYZANTIUM THROUGH THE EYES OF PLASTIC ARTISTS}

\section{Abstract}

This article offers a survey of Byzantine musical imagery, focusing on the diverse thematic fields, both in the religious and secular spheres, associated to such images. In spite of the scarcity of visual testimonies, partly due to doctrinal matters to be studied as well, those that remain do reveal themselves to be most rewarding in showing evidence of the richness and diversity of musical instruments and dances. The analysis of this complex and abundant iconographic corpus confirms once more that Byzantium kept on being a cultural and artistic melting pot for more than ten centuries.

Keywords: Byzantium, iconography, music, instruments, dance, art, miniatures, codices.

DOI: http://doi.org/10.25145/j.cemyr.2017.25.002 


\section{INTRODUCCIÓN}

En el Occidente medieval las manifestaciones musicales en el arte son múltiples y afloran en diversos soportes (escultura, pintura, miniatura, marfiles, metales, cerámica, tapices, etc.), mostrándonos diversas facetas del arte sonoro durante ese período, lo que ha permitido hacer un estudio bastante completo de lo que fue la vida musical en ese tiempo, aunque no haya sobrevivido la mayoría de los instrumentos musicales ni haya llegado hasta nosotros un corpus de obras de este género significativo que nos permita conocer la música instrumental de la Edad Media tan bien como la de épocas posteriores. No obstante, la iconografía musical en la Europa occidental nos ha permitido saber mucho sobre las circunstancias en las que sonaba la música, sobre sus intérpretes y sobre el modo de ejecución de los instrumentos musicales, algo que complementan los textos escritos, históricos y literarios.

Sin embargo, esto no sucede en el Imperio bizantino, lamentablemente, por razones que trataré de explicar aquí. Es verdad que se ha estudiado de forma exhaustiva todo lo concerniente a la música vocal religiosa y que existen renombrados especialistas en este terreno, sencillamente porque el viejo rito bizantino, tan rico en melodías y en géneros musicales, sigue vivo y su tradición, pese a todos los avatares que sufrió Bizancio a lo largo de su historia hasta su desaparición en 1453, se ha conservado. A pesar de ello, hay que señalar que el corpus melódico sufrió en el siglo XIX una transformación importante, al «tonalizarse» sus melodías, pero aun así ha mantenido su modus operandi vocal, su belleza interna y su liturgia.

Ahora bien, ¿qué sabemos de los otros géneros de música, qué sabemos de los instrumentos musicales que se usaron en el imperio a lo largo de sus diez siglos de existencia, puesto que no intervinieron nunca en el culto al ser este eminentemente vocal? Ni siquiera el órgano se usó dentro de las iglesias, a pesar de que en Occidente se convirtió en el instrumento litúrgico por antonomasia hasta hoy en día. Y no lo hizo porque hubo prohibiciones expresas en este sentido en los textos de los Santos Padres que influyeron de forma eficaz en el clero posterior, toda vez que su uso estaba muy arraigado en la sociedad civil e intervenía en las carreras del hipódromo, en diversas ceremonias del palacio imperial, en banquetes, en representaciones teatrales, etc. $\mathrm{Y}$ ¿qué decir de los restantes instrumentos y de su consideración social? En un momento en que el imperio oriental comienza su andadura de forma independiente de Roma debemos plantearnos qué es lo que se conserva del pasado grecorromano y qué se innova, se mejora o se incorpora de otras culturas próximas o lejanas, es decir, contemplar cómo se fue configurando el nuevo instrumentario, que en parte va a ser trasmitido a la Europa occidental de forma paulatina. Pero para ello es necesario conocer cómo operan las fuentes con las que se va a trabajar, que son primordialmente las iconográficas, y en qué medida incide en ellas la conceptuación de la imagen religiosa, muy diferente de la que se tenía en Occidente. Ello afecta sobre todo a los instrumentos musicales y a la danza, que son los dos ámbitos que preferentemente muestra la iconografía, pues la música vocal resulta difícil de plasmar en imágenes para que sea comprensible al espectador, siendo algo invisible. Aun así, existen algunas que presentan coros de cantores, cuyos rostros no denotan ningún esfuerzo muscular por emitir sonidos, como sí ocurre en la Europa del siglo Xv. 


\section{PROBLEMÁTICA DE LA ICONOGRAFÍA MUSICAL BIZANTINA}

Los estudios organológicos dedicados al Imperio bizantino han sido hasta tiempos recientes escasos y fragmentarios, por lo que no se ha podido llegar a conclusiones definitivas. No existe una obra de tipo general sobre el tema y ni siquiera se publicó el volumen proyectado hace cerca de cincuenta años por la VEB Deutscher Verlag für Musik de Leipzig para la Musikgeschichte in Bildern dedicado a Bizancio. Además, resulta sorprendente constatar que en obras fundamentales sobre la música bizantina, tal como A History of Byzantine Music and Hymnography de Egon Wellesz ${ }^{1}$, el tema de la música instrumental y de los instrumentos musicales apenas se trata, con excepción de un pequeño apartado dedicado a la consideración de los instrumentos por los Santos Padres en los primeros siglos ${ }^{2}$ y de una corta mención sobre el órgano y su participación en las ceremonias de palacio ${ }^{3}$. Lo mismo sucede en el artículo sobre Bizancio de Kenneth Levy en el New Grove Dictionary of Music and Musicians en su edición de $1980^{4}$, si bien en la del año 2001, que recoge de nuevo la voz de Levy, ampliada y revisada por Christian Troelsgard, se le dedica otra voz a la música secular redactada por Diane Touliatos ${ }^{5}$, quien aporta una bibliografía básica sobre el tema, en la que se incluyen algunos trabajos suyos que rozan este campo, pues su interés principal, aparte de la música vocal, ha sido el del papel de la mujer en la danza y en la creación musical. Pese a todo ha sido esta autora una de las que más se han ocupado del campo instrumental bizantino, hasta estudios más recientes, al intentar ofrecer una panorámica de los instrumentos, relacionando sus nombres griegos con los latinos y con algunos actuales, además de añadir una sucinta descripción de cada uno de ellos. También trata los géneros de la música profana, mencionando a compositores de este campo. Pero, evidentemente, esta información resumida en una corta voz de dos columnas es de todo punto insuficiente para conocer la paleta instrumental, sus características y su evolución a lo largo de los diez siglos de historia de este imperio.

Tampoco en los tratados e historias generales de los instrumentos musicales se dedica un capítulo a este campo tan sobresaliente y tan necesario, sino que en algunos casos se mencionan de forma somera aquellos instrumentos más representativos que han tenido una marcada influencia en el instrumentario europeo de la

${ }^{1}$ E. Wellesz, A History of Byzantine Music and Hymnography. Oxford, Oxford at the Clarendon Press, reimp. de la 2. ${ }^{\text {e }}$ ed., Oxford University Press, 1971.

2 Ibidem, pp. 91-94.

3 Ibidem, pp. 105-109.

4 K. Levy, «Byzantine rite, music in the», en New Grove Dictionary of Music and Musicians, Londres, Stanley Sadie, 1980, vol. 3, pp. 553-566.

${ }^{5}$ Esta musicóloga de origen griego, profesora en la Universidad de Missouri-St. Louis, ha dedicado gran parte de sus investigaciones a la música bizantina, centrándose en la música vocal, en las danzas femeninas y en las mujeres compositoras. Es verdad que en la voz citada del New Grove habla de los instrumentos musicales, pero la información que ofrece es insuficiente para conocer en amplitud este tema: D. Touliatos, «Byzantine secular music», en New Grove Dictionary of Music and Musicians, Stanley Sadie, Londres, 2000, vol. 4, pp. 756-757. 
Edad Media, de los que varios se conservan en las músicas de tradición oral, como por ejemplo la lyra o giga griega. Es cierto que existen algunos trabajos parciales sobre organología bizantina, como el muy antiguo de Jean Baptiste Thibaut, centrado sobre todo en el órgano ${ }^{6}$, los de Henry George Farmer 7 , Werner Bachmann ${ }^{8}$, Fivos Anoyanakis ${ }^{9}$, Jean Perrot ${ }^{10}$, D.F. Conomos y A. Kazhdan ${ }^{11}$, entre otros ${ }^{12}$, pero, volvemos a repetir, son insuficientes para dar a conocer ampliamente esta parcela, que tanta importancia tiene no solo para la propia historia musical de Bizancio, puesto que los instrumentos tuvieron un papel destacado en la vida de la corte y de la sociedad en general, a juzgar por los testimonios escritos, sino también para el estudio de las trasmisiones de Oriente a Occidente -y también algunas en sentido inverso-, tal y como he mencionado más arriba. Este último punto, centrado en un único instrumento, el arpa-cítara bizantina, lo traté hace ya algunos años en mi artículo «El arpa-cítara (rota): su probable origen bizantino y su trayectoria mediterránea hacia la Europa occidental $\aleph^{13}$, en el que, aparte de hacer un recorrido visual por distintas zonas europeas y de ańadir una relación de obras que contenían imágenes de este cordófono, también aportaba algunas del mundo bizantino.

De esta falta de interés, quizás aparente, por parte de los investigadores se lamentaba hace ya años Joachim Braun en su artículo «Musical instruments in Byzantine illuminated manuscript $»^{14}$, donde comenzaba elaborando un estado de la cuestión, aportando también bibliografía, para pasar a continuación al estudio de los instrumentos musicales representados en los manuscritos griegos que se conservan en las bibliotecas del Patriarca griego de Jerusalén y en la del monasterio de Santa Catalina en el monte Sinaí, pertenecientes casi todos ellos a la segunda Edad de

${ }^{6}$ J.B. Thibaut, «La musique instrumentale chez les byzantins». Échos d'Orient, tomo 4, núm. 6 (1901), pp. 339-347 y tomo 5, núm. 6 (1902), pp. 343-353.

7 H.G. Farmer, «Byzantine Musical Instruments in the Ninth Century». Journal of the Royal Asiatic Society, vol. 57, núm. 2 (1925), pp. 299-304; y «An Early Greek Pandora». Oriental Studies (1953), pp. 59-63.

8 W. Bachmann, «Das Bizantische Musikinstrumentarium», en L. Mokry (ed.), Anfänge der Slavischen, Bratislava, 1966; y The Origins of Bowing and the Development of Bowed Instruments up to the Thirteenth Century. Londres, Oxford University Press, 1969, pp. 33-42. En esta última obra Bachmann se centra, como indica el título del libro, en los cordófonos frotados.

${ }^{9}$ F. Anoyanakis, «Ein Byzantisches Musikinstrument». Acta Musicologica, vol. 37 (1965), pp. 158-165; y Greek Popular Musical Instruments. Atenas, Banco Nacional de Grecia, 1979.

${ }_{10} \mathrm{~J}$. Perrot, L'orgue. De ses origines hellénistiques à la fin du XIII e siècle. París, A. Picard, 1965, pp. 308-330.

${ }^{11}$ D.E. Conomos y A. Kazdhan, «Musical Instruments», en A.P. Kazdhan (ed.), The Oxford Dictionary of Byzantium, Oxford, Oxford University Press, 1991.

12 También el trabajo de T. SeEbass, Musikdarstellung und Psalterillustration im früheren Mittelalter. Studien ausgehend von einer Ikonologie der handschrift Paris Bibliothèque Nationale fonds latin 1118. Bern, Francke Verlag, 1973, se ocupa de imágenes musicales de códices bizantinos, relacionándolas con las del códice objeto de su estudio.

13 R. Álvarez, «El arpa-cítara (rota): su probable origen bizantino y su trayectoria mediterránea hacia la Europa occidental». Revista de Musicología, vol. xxII, núm. 1 (1999), pp. 11-48.

${ }^{14} \mathrm{~J}$. Braun, «Musical instruments in Byzantine illuminated manuscripts». Early Music, vol. viII, núm. 3 (1980), pp. 312-327. 
Oro del Imperio de Oriente y algunos al período Paleólogo. Termina su exposición Braun diciendo que este estado deplorable de los estudios organológicos de Bizancio se debía a la inexistencia de rastreos sistemáticos de las fuentes iconográficas y de su posterior estudio pormenorizado, y no a la carencia de esas mismas fuentes.

Esta afirmación de Braun no nos parece del todo cierta, pues pensamos que las fuentes iconográficas musicales de Bizancio no abundan precisamente, y que una búsqueda rigurosa llevada a cabo en todas aquellas bibliotecas y museos que conservan obras de arte y manuscritos bizantinos no daría el resultado deseado, extrayéndose apenas unas decenas de ejemplos, que serían valiosísimos ciertamente, pero que no podrían compararse con las numerosísimas representaciones musicales que produjo el arte occidental durante la plena y baja Edad Media, a través de las cuales se puede estudiar la evolución de cada tipo de instrumento y también algunas coreografías de danzas. Este hecho se puede constatar poniendo como ejemplo tan solo las fuentes estudiadas por Braun en las bibliotecas citadas. De los treinta y tres manuscritos griegos que posee la biblioteca del Patriarca griego en Jerusalén, que contienen cuatrocientas treinta miniaturas, únicamente en doce hay instrumentos musicales; y en la biblioteca del monasterio de Santa Catalina en el Sinaí, que es una de las mayores del mundo en cuanto a número de manuscritos griegos conservados, con un total de dos mil trescientos diecinueve, la diferencia es aún más sorprendente, pues de los ochenta y cuatro códices miniados con quinientas noventa iluminaciones se encuentran solamente unas pocas escenas musicales. Braun ${ }^{15}$ presenta solo cuatro sin especificar si son las únicas (suponemos que sí lo son).

Además, ¿̇no resulta extraño que un imperio que valoraba muchísimo el órgano, tanto para las ceremonias cortesanas como para los juegos en el hipódromo y otras fiestas palaciegas, e incluso para fines terapéuticos, según se desprende de los escritos de griegos y árabes, y en especial de las informaciones facilitadas por el emperador Constantino VII Porfirogéneta en su Libro de las Ceremonias ${ }^{16}$, no nos haya legado un número elevado de imágenes suyas a lo largo de sus diez siglos de existencia? La única representación bizantina de órgano que incluye Jean $\operatorname{Perrot}^{17}$ en su amplio y documentado trabajo sobre este instrumento, desde sus orígenes en la Antigüedad hasta fines del siglo XIII, es la perteneciente a la base del obelisco que Teodosio I mandó erigir en el hipódromo de Constantinopla (fines del siglo Iv); aunque Braun ${ }^{18}$ cree ver otra de un órgano portátil en el objeto no muy bien definido que sostiene un hombre en una miniatura (fol. $17 \mathrm{v}^{\circ}$ ) del códice griego 3 de la biblioteca del monasterio de Santa Catalina, que nosotros descartamos del todo ${ }^{19}$. Por su parte, Fernanda De' Maffei

${ }^{15}$ Ibidem, pp. 314 y 322.

${ }^{16}$ C. Porphirogénète (905-959), Le Livre de Cérémonies. Ed. A. Vogt, tomo i, libros i y II, París, Les belles lettres, 1935-40; y J. Рerrot, op. cit., pp. 390-392, cita los fragmentos referidos al órgano.

17 Ibidem, lám. Iv.

${ }^{18}$ J. Braun, op. cit., p. 323 y lám. 6 b.

19 Pensamos que debía ser un tipo de objeto relacionado con el banquete que centra la imagen. Cfr.: https://www.pinterest.com.mx/pin/318981586080959081/. 
señala con rotundidad que solo existen tres: la citada del obelisco, la del mosaico sirio de una casa de Mariamín, coetánea del obelisco, y la que aparece en las pinturas de la escalera de la torre suroeste de la catedral de $\mathrm{Kiev}^{20}$. Pero a esas tres imágenes tengo que añadir la representada en el Salterio grecobizantino Hamilton, fol. 41v. ${ }^{\circ}$ del Kupferstichkabinett de la Preussischer Landesbibliothek de Berlín, cod. 78 A 9, de finales del siglo XIII, que no cita ninguno de estos autores. No obstante, somos conscientes de que estas muestras son de todo punto insuficientes para demostrar visualmente la gran importancia del órgano en este Imperio, instrumento que, si no fuera por los documentos escritos, pasaría totalmente inadvertido.

En efecto, son este tipo de fuentes, especialmente el citado Libro de las Ceremonias, las que se explayan en describir las intervenciones del órgano en todas las actividades del palacio imperial, como los desfiles que precedían y seguían a las ceremonias religiosas en las grandes fiestas del año litúrgico, las recepciones ofrecidas a los demes por el emperador en palacio, los banquetes imperiales, los cortejos nupciales o las carreras del hipódromo. Todo esto ha sido perfectamente descrito y comentado por Nikos Maliaras en su libro sobre el órgano en el imperio bizantino durante los siglos Ix y $\mathrm{x}^{21}$, pero las imágenes brillan por su ausencia.

Es por ello que nos reafirmamos en nuestra opinión de que el arte bizantino no ofrece a los especialistas suficientes fuentes iconográficas para el estudio de los instrumentos musicales debido a razones doctrinales extrínsecas a la propia historia de la música ${ }^{22}$, puesto que se sabe que la música instrumental jugó un papel importante en la vida de este imperio, pese a las prohibiciones que hubo desde antiguo por parte de los Padres de la Iglesia, obispos y patriarcas, que se concretarían en ciertos cánones de los Concilios de Laodicea (mitad del siglo Iv) y de Trullo (año 680). Evidentemente, si se prohibía era porque la música instrumental existía y la gente la seguía practicando, pero no se permitía representarla en obras de arte de contenido religioso.

Esa carencia de imágenes instrumentales se podría aplicar presumiblemente a las obras artísticas desaparecidas ${ }^{23}$ en el transcurso de las múltiples vicisitudes

${ }^{20}$ F. De’ Maffei, "Gli strumenti musicali a Bisanzio», en G. Cattin (ed.), Da Bisanzio a San Marco. Musica e Liturgia, Quaderni di Musica e Storia 2, Venezia-Bologna, Fondazione Ugo e Olga Levi-il Mulino, 1997, pp. 61-110, p. 78.

${ }^{21}$ N. Maliaras, Die orgel im byzantinische hofzerimoniell des 9. und 10. Jahrhunderts. Eine Quellen Untersuchungen. München, 1991 (Miscellanea Byzantina Monacensia, 33), pp. 35-189.

22 Esta escasez de fuentes iconográficas en el campo instrumental podemos hacerla extensiva al vocal, al menos hasta el siglo xiII, según lo constata N.K. Moran, Singers in Late Byzantine and Slavonic Painting. Leiden, E.J. Brill, 1986, p. 23.

${ }^{23}$ Se conservan descripciones coetáneas de algunas de ellas, en las que no se mencionan temas musicales, al igual que ocurrió con las existentes que se trasladaron a varios lugares de Europa tras el saqueo que sufrió Constantinopla a manos de los cruzados en 1204. Para este tema puede consultarse el enjundioso artículo de la que fue conservadora del Museo Arqueológico Nacional Á. Franco, Fascinación de Occidente por Bizancio en las Artes suntuarias de los siglos XI y XIII: Iconografía y Liturgia. PDF colgado en 2013 en la red: http://consellodacultura.gal/mediateca/ extras/2013Xelmirez_AngelaFranco.pdf. 
sufridas por Bizancio y, en especial, tras su caída definitiva con la conquista turca en 1453. Las causas de esta escasez de fuentes iconográficas musicales habría que buscarlas, pues, en la peculiar conceptuación que el artista griego y, sobre todo, sus mentores tenían sobre la función de las imágenes en el arte religioso tras la querella iconoclasta (726-843), función muy distinta de la que se le atribuía en Occidente. Hay que tener en cuenta que es en ese momento, segunda mitad de la novena centuria, cuando se produce el auténtico despegue de la iconografía medieval cristiana en su versión griega y es cuando se definen los principios doctrinales que habrían de regir la ordenación y temática de la figuración artística en los templos, que son los que en gran medida impedirán la representación de instrumentos musicales en el arte en manos de los ángeles, que son los intérpretes sempiternos en la Europa occidental.

Pero antes de entrar de lleno en este período o segunda Edad de Oro, debemos señalar que la etapa anterior, la correspondiente a la primera Edad de Oro bizantina (siglos V-VIII), centrada en torno a la época de Justiniano (siglo vI), tampoco es muy proclive a la representación de instrumentos musicales y, cuando estos aparecen, lo hacen en temáticas de tipo profano, representadas en mosaicos de pavimentos, bajorrelieves en piedra o en marfil, en ciertos códices, etc., aunque no falten algunos temas bíblicos tratados en objetos suntuarios, entendiendo que la temática religiosa tal y como hoy la conocemos se desarrolla a partir del siglo IX, una vez finalizado el conflicto iconoclasta, como se ha dicho. Y es que en este primer período de recorrido del imperio de Oriente, se mantienen aún muchos elementos culturales del paganismo, que conviven con los nuevos principios cristianos ${ }^{24}$. Y si esto es así en muchos órdenes de la cultura, también lo es en el ámbito musical, especialmente en lo que afecta al instrumentario, que no estaba bajo el control del clero y mantuvo vivas las formas y tipologías que venían de atrás. La realidad es que varios instrumentos de la cultura clásica grecorromana siguieron utilizándose durante largo tiempo en los distintos ambientes de la vida musical bizantina, puesto que sus imágenes siguen apareciendo durante toda esa primera Edad de Oro, hecho que contrasta con la Europa coetánea, de donde desaparecieron tras las invasiones de los pueblos bárbaros, configurándose aquí un nuevo instrumentario a partir de la época carolingia (siglos IX-X). Y es curioso constatar cómo en el ámbito bizantino también por este mismo tiempo, que es cuando se produce el final de la famosa iconoclastia (843), nos encontramos en las fuentes iconográficas con formas instrumentales nuevas, aunque algunas del pasado se fosilicen pictóricamente, como más adelante explicaremos.

La mayoría de las imágenes musicales de esta primera etapa que nos han llegado han sido tratadas por la historiadora del arte italiana Fernanda De' Maffei en su citado artículo «Gli strumenti musicali a Bisanzio», de $1997^{25}$, y en dos de

${ }^{24}$ A. Ducellier, Bizancio y el mundo ortodoxo. Madrid, Mondadori, 1992, pp. 62-72.

${ }_{25}$ F. De' MaffeI, op. cit., pp. 61-110. Tengo que indicar que esta investigadora, fallecida en 2011 a los 93 ańos, comete algunos errores en lo que se refiere a la terminología y naturaleza de ciertos instrumentos musicales, pues al fin y al cabo ella no era musicóloga y menos aún organóloga, pero sí en cambio nos ofrece textos muy atractivos que contextualizan cada etapa y que yo no voy a reproducir aquí porque el objetivo principal de este artículo se centra en la iconografía. 
ellas otros especialistas han profundizado en alguno de sus instrumentos, dada su trascendencia o su singularidad, como veremos. Pero la realidad es que, si bien este primer período ha sido contemplado de una forma pretendidamente exhaustiva (también es verdad que hay muy pocas fuentes), la aportación de Maffei a la iconografía bizantina del período medio y tardío es bastante pobre por las razones que venimos explicando, es decir, porque probablemente no conocía otras fuentes y, a pesar de ser una gran especialista en el arte bizantino, no tuvo en su época la oportunidad de consultar muchos códices de las grandes bibliotecas. Tampoco se han ocupado de la etapa media otros investigadores, aunque el período final sí que ha sido contemplado en trabajos más recientes por expertos de países que estuvieron bajo la órbita bizantina, pero que ya en ese período final de su historia medieval habían tomado caminos independientes políticamente, por lo que la normativa bizantina prescrita para la representación de las imágenes en los templos había dejado de ejercer su impronta en ellos. Es el caso, por ejemplo, de los estudios de Roksanda Pejovic ${ }^{26}$ sobre las iglesias de Serbia o de Gabriela Ilnitchi Currie ${ }^{27}$, quien se ha centrado en la iconografía musical tardía y postbizantina de los frescos de las iglesias de las regiones de Wallachia y Moldavia, en Rumanía, de los siglos XIV al XVIII, de los que ha extraído muchísimas imágenes musicales, cuya cronología excede con mucho el período acotado para nuestro trabajo, ceńido a los diez siglos de vida del Imperio bizantino. Sin embargo, las fuentes iconográficas provenientes de los períodos Macedonio y Comneno (siglos IX al XIII) están muy poco trabajadas por la escasez y dispersión de las conservadas en numerosas bibliotecas del mundo, en el caso de los códices, que, salvo algunas piezas de marfil y ciertas pinturas murales, son casi las únicas existentes de este período.

Ahora bien, al enfrentarnos al estudio de la iconografía musical bizantina en su totalidad cronológica nos damos cuenta de que esta presenta peculiaridades propias en cada período, por lo que no podemos generalizar ni determinar unas características comunes para toda la historia del imperio. Está claro que los ejemplos que nos han

26 R. Pejovic, Musical Instruments in Medieval Serbia. Belgrado, Ed. Stanojlo Rajcic, 1984, en caracteres cirílicos; $y$ "The Mocking of Christ and other scenes from the cycle of The Sufferings of Christ as illustrated by musical instruments in Southern-European art». New sound: International magazine for music, vol. 2 (1993), pp. 71-93.

27 Esta investigadora y profesora rumana, establecida en la Universidad de Minnesota, ha realizado varios trabajos sobre los frescos de estas iglesias que corresponden a áreas que estuvieron bajo la órbita bizantina, pero que ya en esa época habían escapado de ella. Cfr. «Ottoman echoes Byzantine Frescoes, and musical instruments in the Balkans", en D.A. Buchanan (ed.), Balkan Popular Culture and the Ottoman Ecumene: Music, Image, and Regional Political Discourse (Europea: Ethnomusicologies and Modernities 6), Lanham (Maryland), 2007, pp. 193-224; "Representations of musical instruments in the Byzantine and post-Byzantine iconography», en A. GoulaKi-Voutira (ed.), Musical Instruments in Greece from Antiquity to the Modern Era, Athens, Aristotle University and Piraeus Bank Association, 2010; y sobre todo el catálogo profusamente ilustrado que ha elaborado: "A corpus of pictorial representations of musical instruments and dances in the church frescoes of present-day Romania, Wallachia and Moldavia, ca. 1350 to ca. 1750». Imago Musicae, vol. xxiII (2006-2010), pp. 101-152. 
llegado tanto de la etapa protobizantina como de la llamada primera Edad de Oro están aún vinculados a los modelos grecorromanos por su significado, por su voluntad de realismo, por los instrumentos musicales que encierran y también, en ciertos casos, por los intérpretes escogidos, donde no faltan los seres mitológicos. Pero todos ellos contemplan una faceta de la vida de su tiempo congelada en una imagen tan vívida que a través de ella nos podemos imaginar lo que pudo ser ese mundo musical que tratamos de reconstruir y del que esa obra pictórica o musivaria, escultórica o eboraria muestra una visión particular de un mundo perdido para siempre.

\section{LAS IMÁGENES MUSICALES EN LA ETAPA PROTOBIZANTINA}

Aunque el arte bizantino empieza a fraguarse como arte diferenciado del occidental a partir del siglo $\mathrm{v}$ tras la división del viejo Imperio romano en el 395, con capital el oriental en la vieja Bizancio -rebautizada por Constantino a principios de ese mismo siglo como Constantinopla-, nos vamos a permitir retrotraer el estudio de los instrumentos musicales y su contexto a finales de la centuria anterior, al existir dos magníficas representaciones que nos interesan para nuestros fines por ser muy significativas y estar conectadas ya con imágenes posteriores. Me refiero a uno de los bajorrelieves que presenta la base que sostiene el obelisco que el emperador Teodosio mandó erigir (año 390) en la spina del hipódromo de Constantinopla y que fue traído de Egipto ${ }^{28}$, vía puerto de Alejandría, y al mosaico de una casa siria de Mariamín que se conserva en el Museo de Hama, coetáneo de la anterior. Quiero señalar que sobre dos de sus instrumentos se han hecho estudios monográficos por el interés que han despertado entre los especialistas, ya que incluyen ambas las primeras imágenes que se han encontrado hasta ahora del órgano neumático ${ }^{29} \mathrm{y}$ de las acetábulas del bajo Imperio romano, que fueron cultivados asimismo durante los primeros tiempos de su sucesor el bizantino.

El bajorrelieve de la cara sur del dado que sostiene el obelisco (lám. 1), a pesar del avanzado estado de desgaste de la piedra, ha sido siempre considerado como un testimonio visual muy destacado para conocer la importancia que adquirieron las carreras en el hipódromo en este imperio, carreras presididas por el propio emperador, que con la corona de laurel en la mano va a premiar al auriga ganador de una de ellas, rodeado por toda su corte.

Este interesante bajorrelieve está organizado en dos bandas que contienen personajes de ámbitos sociales diferentes: en el superior se encuentra el emperador y su corte, todos de pie, pues se trata del acto de entrega del trofeo al vencedor, mien-

${ }^{28}$ Había sido erigido por el faraón Tutmosis III para el templo de Karnak (1479-1425 a.C.).

29 Aunque se sabe que el órgano neumático se había inventado ya antes y que en un tiempo convivió con su antecesor el órgano hidráulico, la realidad es que esta es una de sus primeras y escasísimas imágenes en el imperio de Oriente. 


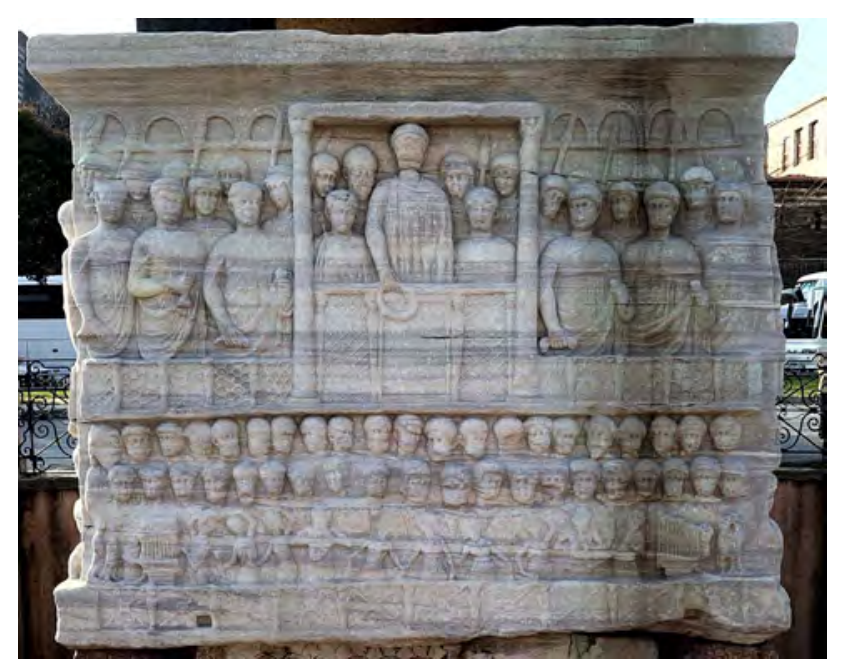

Lám. 1. Bajorrelieve de la base del obelisco de Teodosio (año 390) en Constantinopla.

tras que en el inferior es el público el protagonista, representado solo por cabezas ordenadas en dos filas de forma isocefálica en la zona superior del registro para dejar el espacio restante a los músicos y danzarinas que participan y amenizan el evento, los llamados thymelikoi. Es en este registro y en sus extremos donde se sitúan dos pequeños órganos neumáticos, con sus respectivos intérpretes, cuyos cuerpos quedan medio escondidos detrás de los instrumentos, porque se supone que es en esta zona trasera donde se encuentran las palancas que operan como teclas. Junto a ellos, dos niños accionan con sus pies los fuelles que alimentan los tubos. El órgano de la izquierda presenta ocho caños y el de la derecha doce, lo que indica que el ámbito musical del primero sería de una escala de ocho notas o armonía griega completa (la suma de dos tetracordios) y de armonía y media el segundo (tres tetracordios).

Entre los órganos, que flanquean al grupo musical, se encuentran diez personajes, instrumentistas de viento y bailarinas, dispuestos con una cierta simetría: de izquierda a derecha y a continuación del primer órgano, distinguimos a tres bailarinas contorsionándose mientras sostienen en cada una de sus manos pequeñas campanas que sacuden por medio de un mango y en algún caso por una cinta, moviéndolas por encima de sus cabezas. Es de extrañar que el destacado organólogo Werner Bachmann en su largo y enjundioso artículo sobre este relieve $\mathrm{e}^{30}$ no se haya percatado de que los idiófonos que portan este primer grupo de mujeres son en realidad campanas y no los típicos crótalos «egipcios» propios del mundo antiguo

30 W. BachmanN, «Musikdarbietung im Hippodrom von Konstantinopel». Imago Musicae, vol. XXI-XXII (2004-05), pp. 193-227. 


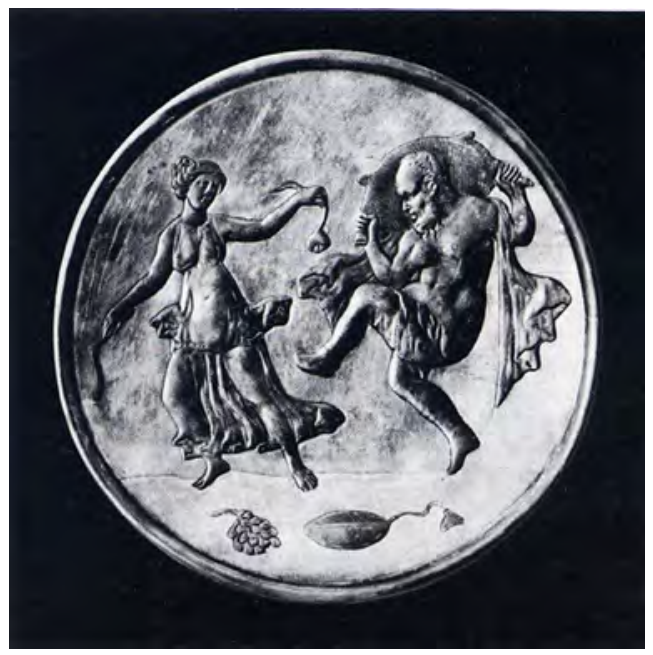

Lám. 2. Plato de plata del siglo viı con una ménade y Sileno. Museo del Ermitage.

que vemos tanto en Egipto como en Grecia y en Roma. Él los ha interpretado en sus dibujos de reconstrucción del relieve como un par de crótalos o pequeños címbalos sujetos al final de dos varillas de madera a modo de tijeretas, que se entrechocan ${ }^{31}$. En cambio, la historiadora del arte Fernanda De' Maffei ha hecho la interpretación correcta $^{32}$ y ofrece otros ejemplos de danzarinas con campanas más tardíos, como el que muestra un plato de plata del siglo viI (lám. 2), concretamente de la época ya del emperador Heraclio (610-641). El plato se realizó en un taller de Constantinopla y se encuentra hoy en el Museo del Ermitage de San Petersburgo. En él se ha dispuesto al viejo y gordo Sileno danzando junto a una ménade, quien con falda vaporosa se mueve al ritmo del tintineo que realizan dos pequeñas campanas (de latón o de plata) cogidas a los extremos de cintas de tela, por lo que la danzarina no controla directamente el sonido del idiófono, sino que ese tintineo se produce por las evoluciones y giros de la cinta que maneja con habilidad, al mismo tiempo que describe figuras en el aire. La presencia de campanillas en manos de danzarinas se sigue viendo en códices bizantinos más tardíos, de los que luego hablaremos. Debía tratarse de una costumbre típica de este ámbito, porque este uso de las campanas no lo hemos visto en las altas culturas de la Antigüedad. Al seguir con la relación de músicos de este bajorrelieve, nos encontramos luego con un flautista y su siringa de ocho tubos, otras tres danzarinas menos exaltadas que las anteriores que se cogen de la mano y se levantan el borde de la falda mientras realizan pausadamente una

${ }^{31}$ Ibidem, p. 201.

32 F. De' MAfFei, op. cit., p. 68. 


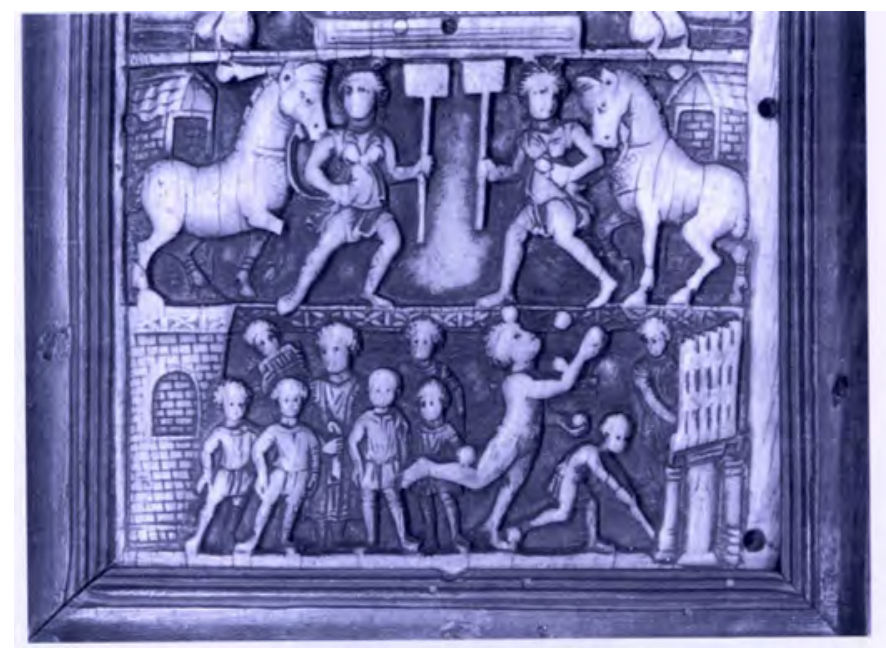

Lám. 3. Díptico de marfil del cónsul Flavio Anastasio (año 517). Biblioteca Capitular de Verona.

danza conjunta; y completando el registro otra bailarina esta vez sí con crótalos y el brazo izquierdo elevado mientras sacude el idiófono, un auletista y un soplador de trompa que se encuentra junto al órgano de la derecha ${ }^{33}$. Desde luego, es un cuadro musical muy interesante que nos habla de cómo una música muy rítmica y vibrante, con melodías a cargo de la flauta de Pan y del aulós o doble oboe, a los que sostienen los largos sonidos de los órganos y los timbres más graves de la trompa, intervenía en el momento cumbre en que va a ser laureado el vencedor, a quien por cierto el escultor no retrata porque seguramente no quería restarle importancia al emperador.

Vemos, pues, este primer ámbito en el que interviene la música en Bizancio: el hipódromo, en el que no solo se celebraban las carreras de carros, sino que también operaba como circo o foro de espectáculos diversos y de entretenimiento para el pueblo. Y es esto en síntesis lo que nos muestra una placa de marfil, donde de nuevo aparece el órgano, pero esta vez el viejo órgano hidráulico (lám. 3), pues así lo indican las dos cubas que flanquean el soporte del instrumento en este pequeñísimo relieve y también la palanca para manipular su mecanismo, que maneja un joven. Detrás del órgano está el organista de pie.

${ }_{33}$ Nos sorprende también que al cuerno, cuya forma curva y cónica es tan evidente, lo llame Bachmann salpinx, cuando este era el nombre de la trompeta recta en la antigua Grecia, y lo compare con el instrumento de este tipo que aparece en la célebre terracota de Alejandría, p. 205 de su artículo. En cambio, al modelo de aerófono del dado del obelisco los griegos lo denominaban kerax y los bizantinos boukina, derivado del latín buccina. 


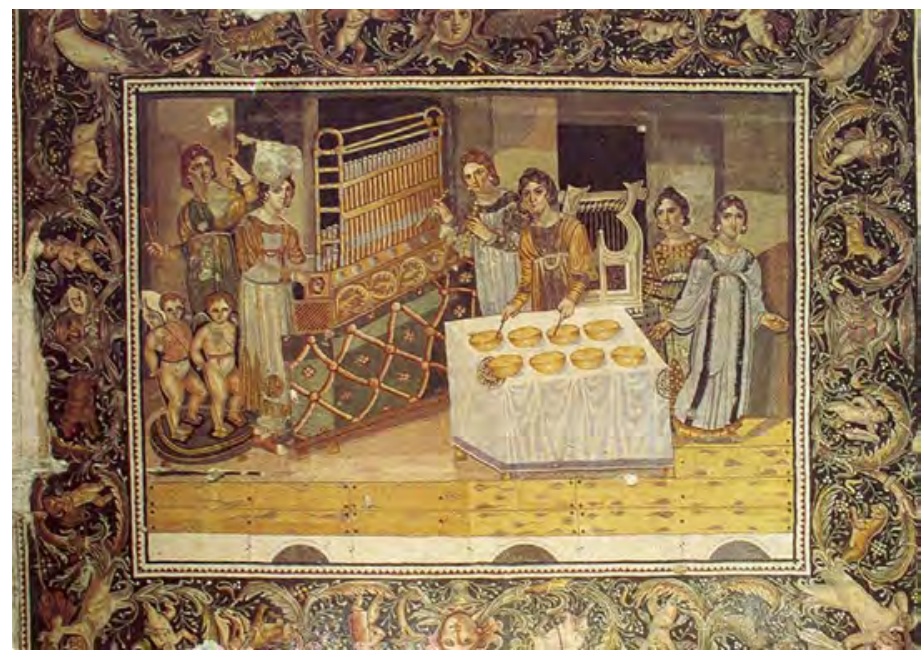

Lám. 4. Mosaico de Maryamin, finales del siglo iv. Museo de Hama.

Se trata del díptico del cónsul Flavio Anastasio del año 517 que se conserva en la Biblioteca Capitolare de Verona. En el registro inferior de una de sus placas, que se ha dividido en dos bandas, y a los pies del cónsul, se han tallado algunos de los usos del hipódromo: las carreras de carros, representadas por dos caballos y sus palafreneros, y abajo una exhibición circense con juegos malabares. Aparte del órgano, que se encuentra en el extremo derecho, se ve a un grupo de nińos con su maestro o director en el izquierdo, posiblemente cantando, y tras ellos un instrumentista con flauta de Pan. De nuevo aquí se nos muestra ese binomio del órgano y la siringa, lo que nos obliga a realizar una nueva lectura del bajorrelieve del obelisco de Teodosio, pues es posible que a cada órgano le correspondiera un conjunto musical diferente: el de la izquierda interactuaría con la siringa y el ritmo de las campanitas, mientras que el de la derecha lo haría con el aulós y la trompa, más los crótalos, es decir, al órgano más pequeño y de sonidos más agudos le corresponderían los timbres más dulces de la flauta múltiple, mientras que el órgano mayor acompañaría al aulós, que con sus dos tubos de doble lengüeta realizaría una melodía bastante penetrante y estridente, puntuada por los sonidos más graves de la trompa. Entendemos que el escultor nos ha querido mostrar aquí el modo de ejecución de la música en este espacio al aire libre, con dos formaciones diferentes que posiblemente alternarían sus intervenciones, lo que nos da pie a pensar que cada una pertenecería a uno de los dos famosos grupos rivales de los «verdes» y de los «azules», resuelto en este único registro de una forma bastante ingeniosa. En el centro, la danza más pausada y elegante, dividiendo la música de cada una de las facciones.

Si este bajorrelieve que acabamos de describir encierra una información muy valiosa para nuestros fines, el mosaico sirio llamado por los arqueólogos de las «muchachas músicas», también del último cuarto del siglo IV (lám. 4), que ocupaba el 
pavimento de una habitación en una residencia privada de Mariamín, conservado en el Museo de Hama en Siria ${ }^{34}$, es una de las más completas y vívidas representaciones de la actividad musical en esta población del mundo oriental del Imperio romano.

El trabajo que ha realizado el musivario es admirable, equivalente a lo que hubiera podido ser una fotografía de un instante en el curso de una audición musical, dispuesta sobre un estrado de madera, que ha hecho pensar a algunos investigadores que se trata de un escenario de teatro ${ }^{35}$. Para mí, en cambio, este cuadro tan colorista y expresivo constituye un testimonio singular de un concierto privado en la casa de algún rico terrateniente de la zona, del que se ha querido dejar constancia visual para la posteridad con el afán de perpetuar esta audición, signo inequívoco del cultivo de la música en su vivienda, del papel que en ella jugaban las mujeres y del estatus social que le confería la posesión de los mejores instrumentos musicales del momento, como era la gran cítara de caja o el órgano neumático, que aunque no era de invención reciente, sí que ya por entonces había desbancado al viejo y pesado hydraulis. Desde luego, aun sin conocer la mayoría de los mosaicos sirios de esta época, puedo afirmar que el realismo que su autor le ha imprimido a esta escena no tiene parangón en la musivaria romana. Es como si este le hubiera pedido a sus protagonistas interrumpir la actuación un minuto para mirarlo a él mientras las captaba, no con su cámara, evidentemente, sino con un dibujo previo. Pero no todas han vuelto su mirada al frente, sino que dos de ellas siguen concentradas en su tarea (la citarista y la crotalista). Las seis jóvenes van ataviadas con vistosas túnicas, algunas estampadas, ceñidas bajo el pecho con un cinto, y también con mantos $^{36}$. Sus cabellos van recogidos hacia atrás según la moda, luciendo también pendientes en las orejas. Todos los rostros son diferentes, así como su color de pelo y sus peculiares miradas, incluso me atrevería a decir que se nota la diferencia de edad de alguna de ellas, como la citarista, quien parece ser mayor que las restantes. Todo ello nos habla de auténticos retratos de estos personajes femeninos.

Las seis mujeres tañen distintos instrumentos musicales pertenecientes a tres de sus cuatro familias: la gran cítara situada sobre una mesa en el centro y atrás, como

${ }^{34}$ Hay un estudio temprano realizado por A.R. Zaqzuq y M. Duchesne-Guillemin, «La mosaïque de Míriamin conservée au Musée de Hama». Les Annales Arabes Syriennes, vol. xx (1970), pp. 93-105. Citado por F. De’ Maffei, op. cit., p. 64.

${ }_{35}$ Cfr. J. Balty, Mosaïques antiques de Syrie. Bruxelles, Musées royaux d'art et d'histoire, 1977; y G. DaregGi, «Scena di concerto in un interno: il mosaico tardo-antico da Mariamîn», en B. Brumana et al. (eds.), Musica e immagine tra iconografia e mondo dell'opera: Studi in onore di Massimo Bogianckino, Florence, Olschki, pp. 19-30. Ambos trabajos vienen citados y comentados por P. GA-

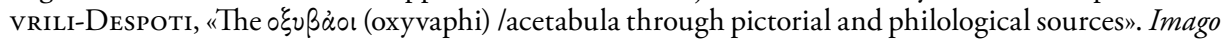
Musicae. International Yearbook of musical iconography, vols. XXI-XXII (2004/05), Libreria Musicale Italiana, Lucca 2006, pp. 49-65. Aunque este autor se centra en las acetábulas, tal y como indica el título de su artículo, también extiende su disertación al espacio donde se celebra el concierto y a las intérpretes, su condición y su vestuario.

${ }^{36}$ Desde luego este mosaico sería muy útil para la historia de la indumentaria del bajo imperio en el área oriental. 
representante de los cordófonos; el órgano neumático y el aulós ${ }^{37}$, de los aerófonos, y los crótalos, los pequeños címbalos y las acetábulas de los idiófonos, mientras brillan por su ausencia los membranófonos. También la danza está representada aquí por medio de los pasos que inicia la muchacha de la derecha mientras tañe sus pequeños címbalos de dedos, los cheirocymbali.

Cada uno de los instrumentos está representado con mucha precisión, mostrando sus elementos característicos, comenzando por la gran cítara de caja, que se presenta de espaldas, elaborada con maderas de diferentes tonos y unos brazos bien labrados en madera clara con molduras, unidos a un yugo que rematan dos discos, ruedas o molettes $^{38}$. También se han mostrado las collopès o pequeños trozos de cuero que unen las ocho cuerdas al yugo. No cabe duda de que es un instrumento de lujo por su buena hechura y su tamaño, propio de los músicos profesionales. El plectro no se muestra en la imagen. Junto a esta instrumentista vemos a la auletista, que sostiene en cada mano uno de los dos tubos característicos del aulós, en los que se han detallado todos sus elementos, como su embocadura de doble lengüeta, la oliva y el cuerpo con sus orificios. Los tubos no son tan largos como los que vemos en la cerámica griega de los siglos V-IV a.C., lo que indica que el sonido debía ser bastante agudo. Esta intérprete es bastante rara, porque se sabe que en el imperio tanto los hombres jóvenes como las mujeres rechazaban el aprendizaje de este aerófono, al ocasionar problemas de deformación en la cara. La presión que había que ejercer en las mejillas para insuflar el aire en el tubo y poner en vibración la doble lengüeta era la causante de este problema. Por tanto, esta es una imagen poco frecuente ${ }^{39}$. En la esquina de la izquierda tenemos a la crotalista, que mira al par de varillas con pequeñas chapas metálicas que sostiene en su mano izquierda, dispuesta a entrechocarlas, mientras su mano derecha empuña otro par.

Hasta aquí todos los instrumentos mencionados se pueden encontrar en otras muchas imágenes del Imperio romano, aunque no sea conformando esta combinación. Pero lo verdaderamente novedoso de este mosaico sirio es que nos presenta un magnífico ejemplar de órgano neumático y una de las dos únicas imágenes que tenemos de las famosas acetabulae que menciona Casiodoro (490-583) y mucho más tarde Isidoro de Sevilla (ca. 556-636), además de otros autores griegos.

En efecto, como ya hemos dicho más arriba, esta imagen del órgano neumático es una de las cuatro que hasta ahora se han encontrado de este instrumento en los diez siglos de historia de Bizancio y, aunque pertenece a una etapa cronológica

37 Suponemos que en esta parte del imperio se seguiría utilizando la terminología griega y no la romana de tibia, que sería la que le correspondería, si así lo fuera.

${ }^{38}$ Los términos franceses molettes y collopès, que utilizamos para denominar algunos elementos de la cítara, están tomados de D. Paquette, L'instrument de musique dans la céramique de la Grèce antique. París, Université de Lyon II. Publications de la Bibliothèque Salomon Reinach, Diffusion de Boccard, 1984, pp. 91-97.

${ }^{39}$ Cfr. Ch. Vendries, «Masculin et féminin dans la musique de la Rome antique. De la théorie musicale à la pratique instrumentale». CLIO. Histoire, Femmes et Sociétés. Musiciennes, vol. 25 (2007), pp. 1-13. 
temprana, la consideramos tan importante como para no prescindir de ella. Al fin y al cabo, la historia del hydraulis se circunscribe a los siglos del Imperio romano que por entonces finalizaba su largo ciclo, mientras que este instrumento neumático es ya un instrumento propiamente medieval que vamos a ver crecer en el Imperio bizantino, de donde llegará a Europa en el siglo Ix. El modelo que exhibe el mosaico es de un tamaño equivalente al de un órgano positivo del Renacimiento, pues ninguna de las imágenes medievales muestra esta tipología tan grande. Quizás, la única que se le asemeje sea la que nos muestra el Salterio de Stuttgart (año 830) en su folio 163v. ${ }^{\circ}$. Situado sobre un pedestal que va cubierto por una colorista y ornamentada tela de paño, el cuerpo del órgano está configurado por un armazón metálico que soporta los 19 tubos largos que se apoyan en su trasera, cruzada por dos listones, mientras que por un extremo asoman otros ocho tubos pequeños de distintas alturas, que debían ser muy agudos por la gran diferencia de longitud que tienen con relación a los primeros. Ello nos hace pensar que posiblemente continuarían paralelos a los grandes por todo el frente del instrumento, que lógicamente queda fuera de la imagen. Era en este frente donde se disponían las palancas de las teclas que se supone manipula la organista que está de pie. ¿Esta doble hilera de tubos podría responder a dos registros diferentes? Desde luego sabemos muy poco de los instrumentos de este período temprano y no hemos visto un órgano con este armazón metálico en ninguna imagen ni de la Antigüedad ni de la Edad Media. Es algo único, pues lo que se muestra en las pinturas de la catedral de Kiev varios siglos después (siglo XII) es sencillamente una caja de madera sin que aparezca nada de su interior. Aquí, en cambio, casi todo queda a la vista. A la derecha de la organista y a la izquierda de la imagen se ven dos putti con sus alas, que tienen el cometido de manejar el gran fuelle de piel de toro y contorno curvado que reposa sobre unas patas y del que sale un portaviento. Los pies de estos seres descansan sobre piezas de madera partidas por la mitad, en las que se apoya cada pie y que son las que manipulan el fuelle y consiguen regular la entrada del aire ${ }^{40}$. El musivara fue tan detallista que quiso mostrar cómo en ese momento de la toma de la imagen las piernas derechas de ambos putti cargaban el peso y aplastaban el fuelle por el frente de cara al espectador, mientras que las izquierdas estaban más elevadas, indicando así que el aire volvía a ocupar su sitio en ese sector del receptáculo. Ambos niños se agarran a una especie de bastón que va fijado a las piezas de sus pies y que les facilitaba el juego del fuelle. Más tarde, en la Edad Media, vemos que el fuellista se sujeta a una gran barra para poder ejercer su oficio, que debía requerir mucha fuerza, energía y habilidad ${ }^{41}$. Es curioso que en una pintura tan realista se incluya a estos seres mitológicos desempeñando este oficio, lo que pone de manifiesto que en el pensamiento de las gentes de esa época lo real y lo imaginario podían convivir sin ningún problema.

40 Cfr. J. Perrot, op. cit., p. 263, habla de los follis, es decir, del fuelle generador y del compensador de aire, necesario este último para estabilizar la entrada de este a los tubos e impedir la interrupción del sonido.

${ }^{41}$ Cfr. las imágenes de los manuscritos del St. John College de Cambridge (siglo XII) y la del Salterio de Belvoir Castle (siglo XIII), reproducidas por J. Perrot, op. cit., láms. xxv y xxviI. 
Por último, nos queda ocuparnos del idiófono percutido que centra nuestra mirada en el mosaico, formado por un juego de ocho recipientes, de bronce supuestamente por su color amarillo, a modo de tazones o cuencos, que reposan sobre una mesa con mantel y que son percutidos en sus bordes por medio de varillas posiblemente metálicas por una de las seis jóvenes. Evidentemente, ha sido lo más llamativo de este mosaico por su singularidad, ya que tan solo existe otro ejemplo pictórico que los muestra ${ }^{42}$. Se trata, probablemente, de las acetabulae que Casiodoro menciona en su De Musica, cap. 5 del tratado De artibus ac disciplinis liberalium litterarum. El término latino común significa vasija o recipiente y se aplicaba a los címbalos. Casiodoro emplea el vocablo en plural, aludiendo sin duda a un juego de varios, y lo incluye entre los instrumentos de percusión, al mismo tiempo que determina que pueden ser de bronce o de plata (acetabula aenea et argentea). San Isidoro en sus Etimologías (lib. III, cap. XXII) recoge el término de Casiodoro y, al enumerar los distintos tipos de instrumentos que integran la tercera parte de su división de la música, denominada por él rítmica, cita, además del cymbalum, «las acetabula aenea et argéntea», expresión que sin duda ha tomado de Casiodoro, pues da la impresión de que no las conoce. Pues bien, estas vasijas, así llamadas porque servían para contener el vinagre en la vida doméstica, se usaron también con fines musicales, como se muestra en esta imagen estudiada monográficamente por el investigador Paraskevi Gavrili-Despoti, quien las denomina por su nombre griego

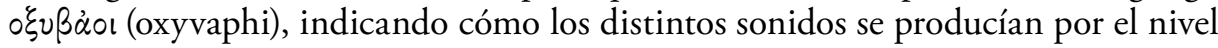
de líquido que contenían, ya que las ocho tienen las mismas dimensiones. Las asocia a las cuatro que aparecen en una miniatura del Génesis de Viena (Österrichiche Nationalbibliothek de Viena, ms. theol. gr. 31, fol. 17v. ${ }^{\circ}$; lám. 5), cuyo color gris indica que son de plata.

Este famoso códice fue realizado a finales del siglo v en Antioquía, según ha podido demostrar Fernanda De' Maffei ${ }^{43}$, descartando así su datación anterior en el siglo vi. El instrumento se inserta en la escena bíblica del banquete del faraón, en el que José interpreta sus sueños (Génesis, 41, 14-36) y en ella, aparte de la percusionista, porque también aquí son las mujeres las que realizan la música, se ve a una auletista, de manera que volvemos a ver ese dúo como en Mariamín. De todas formas, quiero hacer hincapié en que la percusionista no golpea con su varilla los bordes de los recipientes como en el mosaico de Mariamín, sino que percute uno de ellos de forma clara en el centro del círculo como si fuera una superficie plana y no un cuenco. Esta evidencia, junto con las líneas blancas que marcan la mitad de los círculos por su frente, nos hacen dudar de su forma cóncava, pues en la mente del miniaturista podrían corresponder al brillo que se desprende de un borde curvo. ¿Se trataría aquí más bien de una especie de gong o mejor de tam-tam, puesto que

${ }^{42}$ La singularidad de esta imagen ha generado el trabajo monográfico realizado por P.

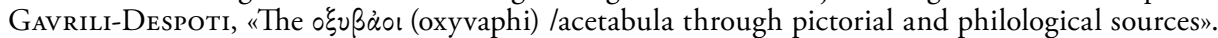
Imago Musicae. International Yearbook of musical iconography, Lucca, Libreria Musicale Italiana, vols. XXI-XXII, 2004/05 (2006), pp. 49-65.

${ }^{43}$ F. De' MafFeI, op. cit., p. 65. 


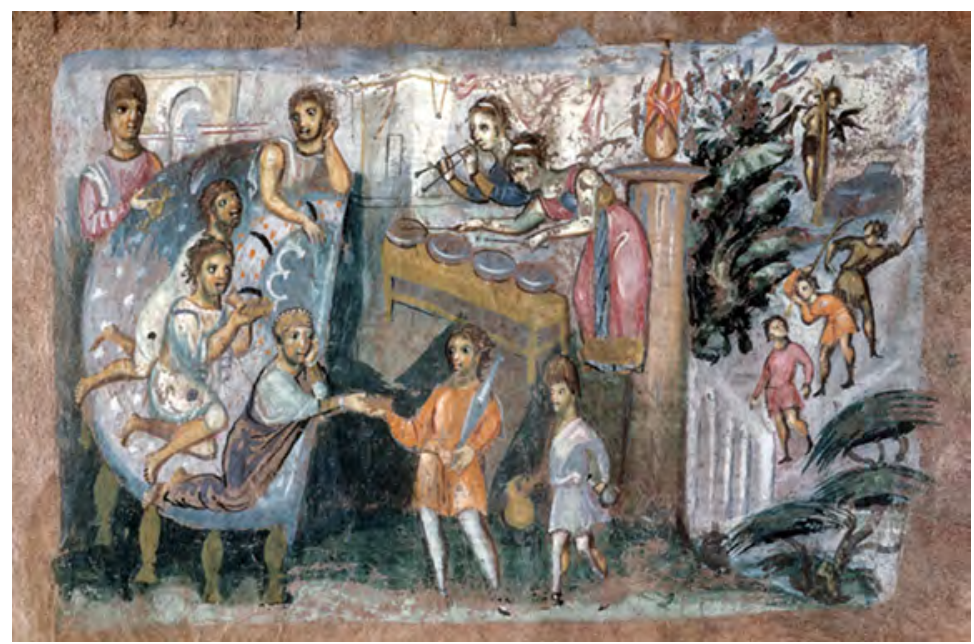

Lám. 5. Génesis de Viena de finales del siglo v. Österrichiche Nationalbibliothek de Viena, Ms. Theol. gr. 31, fol. 17v. ${ }^{\circ}$.

carecen de la protuberancia central? Al no tener más ejemplos sobre esto nada podemos afirmar con certeza. De todas formas, lo que está claro es que, dado el origen sirio de estas dos obras y que también Casiodoro, que fue uno de los autores que los mencionó, procedía de una familia de Siria, debemos convenir que fue en esta zona del Próximo Oriente donde se cultivaron, al menos durante los comienzos del Imperio bizantino. Sin otros testimonios posteriores, debemos pensar que su uso se perdió.

Por último, no debemos pasar por alto la relación entre el número de elementos y su ámbito musical: ocho en Mariamín y cuatro en el Génesis de Viena, lo que apunta a afinaciones concretas en el ámbito de una escala de ocho sonidos (armonía griega) en el primer caso y de un tetracordio en el segundo, algo de lo que también se percató el mencionado Paraskevi Gavrili-Despoti ${ }^{44}$.

Hemos de tener en cuenta, asimismo, que las acetábulas se homologaban a los címbalos y, aunque fueran hondas y de tamaño mayor que los típicos címbalos, las danzarinas los utilizaban para sus bailes atados a sus manos y a los tobillos, como nos lo muestra un mosaico del Museo Arqueológico de Madaba, en Jordania, del siglo vi (lám. 6).

En la imagen se puede ver el tamaño de estos címbalos, que sobrepasa el largo de una mano, y también su curioso modo de ser entrechocados: el de la mano derecha golpea el del pie izquierdo y el de la izquierda el del derecho, para lo cual se necesitaba una gran habilidad y agilidad por parte de la danzarina para no enredarse y caerse. Junto a ella un fauno desnudo la acompaña en la danza.

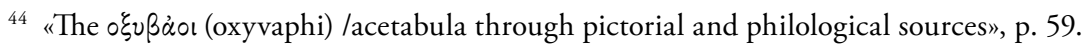




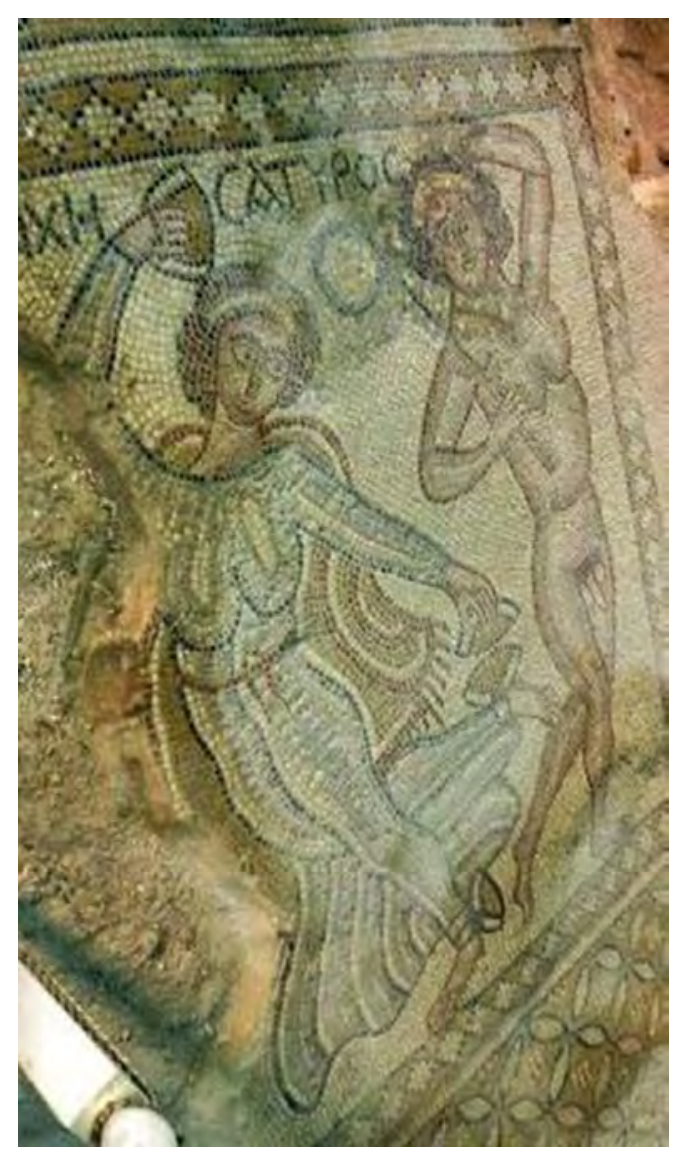

Lám. 6. Mosaico del Museo Arqueológico de Madaba, siglo vi. Jordania.

\section{LAS IMÁGENES MUSICALES EN LA PRIMERA EDAD DE ORO}

De la esfera doméstica, palaciega o del hipódromo de las imágenes anteriores, pasamos ahora al mundo del teatro, representado por un interesante y hermoso altorrelieve de marfil trabajado en un panel con tres registros del llamado Díptico de Bourges (siglos v o vi), conservado en el Cabinet des Medailles de la Bibliothèque National de París (lám. 7).

En las quince figuras, distribuidas en las tres bandas, alternan actores, algunos con sus máscaras, y músicos. Son hombres y mujeres dispuestos a salir a escena con todos sus atrezzi. En el registro superior está representada una citarista que con su grueso plectro rasguea las cuerdas de una cítara, medio oculta por el cuerpo de otra mujer. De ella se ve parte de la caja, de las cuerdas y del yugo con sus 


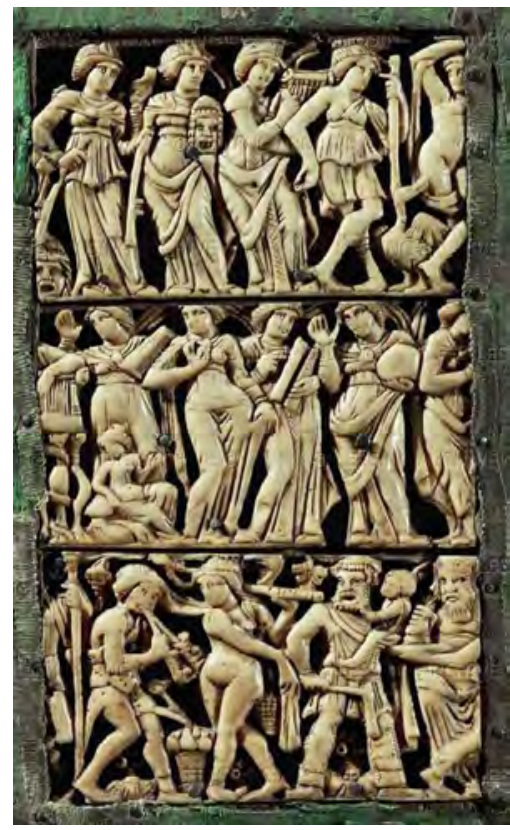

Lám. 7. Panel del Díptico de Bourges, siglos v o vi. Cabinet des Medailles de la Bibliothèque National. París.

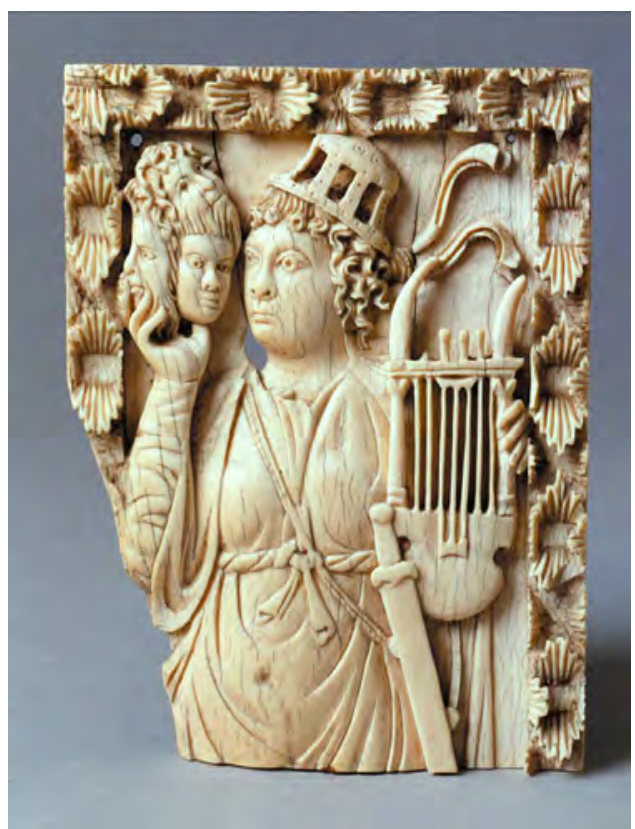

Lám. 8. Actriz en el teatro. Marfil del siglo vi del Staatliche Museen de Berlín.

discos terminales. Otro cordófono similar se sitúa sobre una columna en el extremo izquierdo de la segunda banda, mientras que dos aerófonos aparecen en el registro inferior, uno soplado por un pastor, y el otro sostenido en alto con su mano izquierda por una bailarina desnuda, que no hace ademán de tocarlo, pues con la otra mano mueve un gran velo que cuelga de su hombro derecho. Se trata de un aulós frigio el primero, que pese al corto espacio de que disponía el eborario ha podido mostrar sus características esenciales, con uno de sus dos tubos curvado en su final, y el segundo es una flauta travesera, aerófono nacido en la cultura etrusca, que, como veremos, va a tener un gran porvenir en Bizancio. Incluso se exportará a la Europa occidental en la época de las Cruzadas. Curiosos, pues, estos aerófonos, sobre todo el primero, del que existen poquísimos ejemplos iconográficos en el arte romano. Tampoco este tipo de flauta se prodigó mucho en el arte hasta la segunda Edad de Oro bizantina. Bajo este instrumento y sobre una cesta con frutos se pueden ver unos crótalos, pero solo un par, con sus varillas de madera y sus pequeñas chapas metálicas fijadas al final de los palos. Abigarrada escena esta con tantos personajes dispuestos a actuar, pero que nos da una idea del rico mundo de los participantes en las pantomimas y en los mimos que aún se seguían celebrando en variados espacios ad hoc.

Y de las cítaras aquí presentes, pasamos a otras también labradas en marfil y con características similares, alguna relacionada con el mundo del teatro, como la 


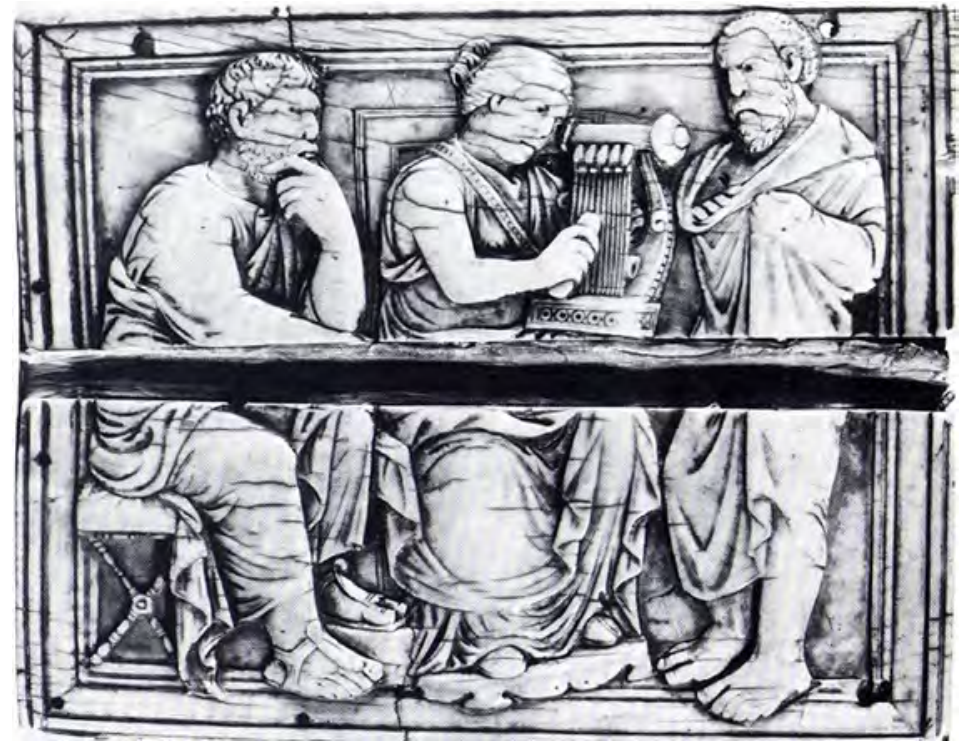

Lám. 9. Marfil del siglo v con Erato entre dos filósofos. Bibliothèque de l’Arsenal n. ${ }^{\circ} 1169$.

que se puede ver en un marfil del siglo vi del Staatliche Museen zu Berlín (lám. 8), en manos de una musa que lleva un extraño sombrero.

Este personaje femenino sostiene en su mano derecha las tres máscaras que corresponden a los géneros teatrales (satírico, cómico y trágico ${ }^{45}$, mientras que con la izquierda sujeta una lira, cordófono más pequeño y ligero que las cítaras, con unas pequeńas columnas que hacen de brazos, rematadas por cuernos que recuerdan los de antílope de las liras griegas primitivas. Tiene siete cuerdas y un pequeño cordal sobre la tapa armónica para solo tres de ellas. Nos preguntamos si esta representación responde a un instrumento real o si se trata de una copia elaborada tan solo para una actuación teatral, como se hará siglos más tarde durante el Renacimiento.

A este marfil se suman otros tres más con imágenes de cítaras similares a las del Díptico de Bourges (lám. 9). La primera es del siglo v y representa a Erato sentada en el centro con su cítara de caja apoyada sobre su pierna izquierda, mientras rasguea las once cuerdas del cordófono con el característico plectro grueso, flanqueada por dos filósofos que aparecen muy concentrados en la música.

Este tipo de cítara labrada en marfil, que se conserva en la Biblioteca del Arsenal, en París, muestra todas las características típicas de esa época, como sus brazos curvados e inclinados hacia atrás, su estrecha caja decorada, los discos que

${ }^{45}$ F. De’ Maffei, op. cit., pp. 63 y 70. 


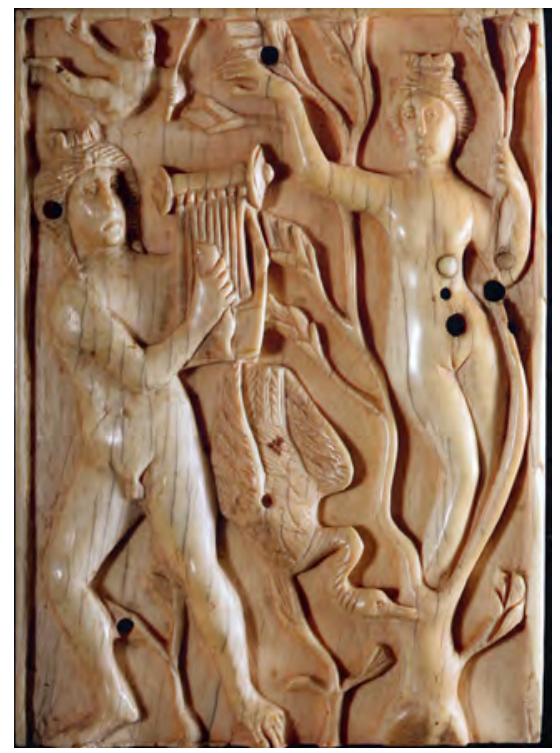

Lám. 10. Marfil con Apolo y Dafne, siglo vi. Museo Nazionale de Rávena.

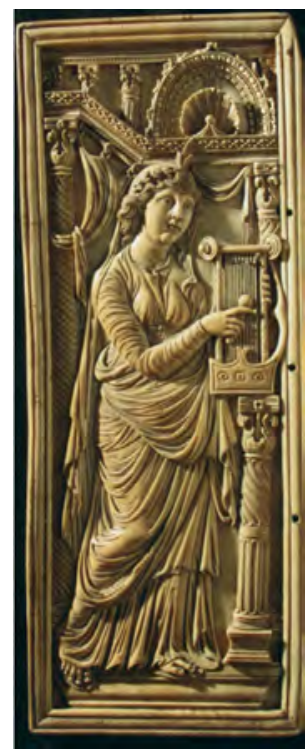

Lám. 11. Detalle del díptico «El Poeta y la Musa». Tesoro de la catedral de Monza.

cierran el yugo en sus extremos y las tiras de cuero que fijan las cuerdas a aquel. Pero también aparece aquí el rodillo que ejerce de puente en la parte inferior trasera de las cuerdas, sobre el cual también se vislumbra la mano izquierda abierta de la instrumentista apagando las vibraciones de aquellas cuerdas que no debían sonar. Creemos que una imagen así, o muy parecida, debió tomarse como modelo de las imágenes posteriores de cítaras, pero, eso sí, con interpretaciones personales y erróneas por parte de los miniaturistas, como se verá.

El segundo marfil con cítara tiene una fecha que oscila entre los siglos v y vi y representa el mito de Apolo y Dafne, habiendo escogido el eborario el momento en que esta se está transformando en laurel, mientras el dios rasguea con un gran plectro las siete cuerdas de esta nueva cítara de caja. El instrumento lo apoya sobre un tronco de árbol a modo de columna, por el que se desliza un ave con su cabeza y el pico hacia abajo, este último agarrando el tronco del laurel. La cítara muestra de forma esquemática todos sus elementos, pero sobre todo llaman la atención los dos grandes discos que rematan los extremos del yugo (los molettes), que son exageradamente grandes. Se conserva en el Museo Nazionale de Rávena (lám. 10).

Y junto a esta imagen tan expresiva, nos encontramos en el díptico del Tesoro de la catedral de Monza con una musa tañendo de nuevo la cítara de caja junto a un poeta, cada uno tallado en una de las hojas del díptico (lám. 11). El instrumento aquí está mucho mejor trabajado que en los ejemplos anteriores, pues su caja presenta un diseño artístico de doble curva cóncava en el borde superior que se prolonga en los brazos de forma muy elegante, mostrando, además, tres pequeños adornos incisivos. 


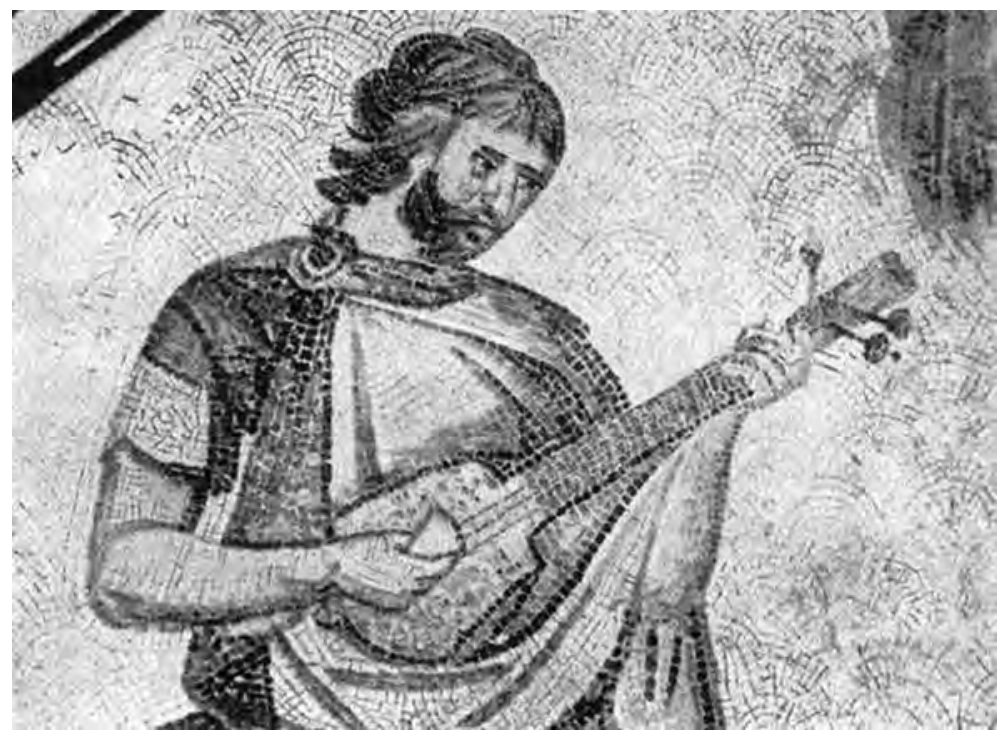

Lám. 12. Mosaico del pavimento del peristilo del palacio imperial de Constantinopla, siglo vi.

Pero aparte de los brazos, cuya función parece ser meramente ornamental, posee dos columnas rectas torneadas flanqueando sus nueve cuerdas. La de la derecha es agarrada por la mano izquierda de la instrumentista para poder mantener el instrumento fijo y rasguear las cuerdas con el plectro de cabeza redonda que manipula la derecha. Aquí también destacan los molettes de los extremos del yugo y las collopès o tiras de cuero que sujetan las cuerdas a este. El tamaño del instrumento es lo suficientemente grande y pesado como para tener que apoyarlo sobre una columna, como ya hemos visto en otras imágenes. De este cordófono debemos retener para imágenes posteriores esa rectangularidad que configuran el yugo con la caja y las cuerdas flanqueadas por esas columnas torneadas, lo que se convertirá más tarde en un simple rectángulo, casi esquemático, sin comprender el miniaturista cuáles eran exactamente los elementos que lo conformaban y a qué respondían.

Y del ámbito culto, en el que hemos visto distintas propuestas, pasamos al popular representado por pastores en el campo o cuidando su rebańo mientras se entretienen con la música: unos con sencillos cordófonos y otros con aerófonos, posiblemente de lengüeta simple, tipo clarinete. El primero se encuentra en el pavimento de mosaicos del gran peristilo del palacio imperial de Constantinopla, construido en el siglo vi, donde se despliegan diversos animales domésticos, fieras y aves a modo de zoológico mudo e inerte. Entre ellos se ven árboles y algunas figuras humanas en tareas cotidianas, destacando la del pastor músico (lám. 12), al que se ha querido identificar con Orfeo.

Está sentado sobre una roca y el cordófono que tiene entre sus manos es de largo mástil con trastes y con tres clavijas insertas directamente en él. La forma de 


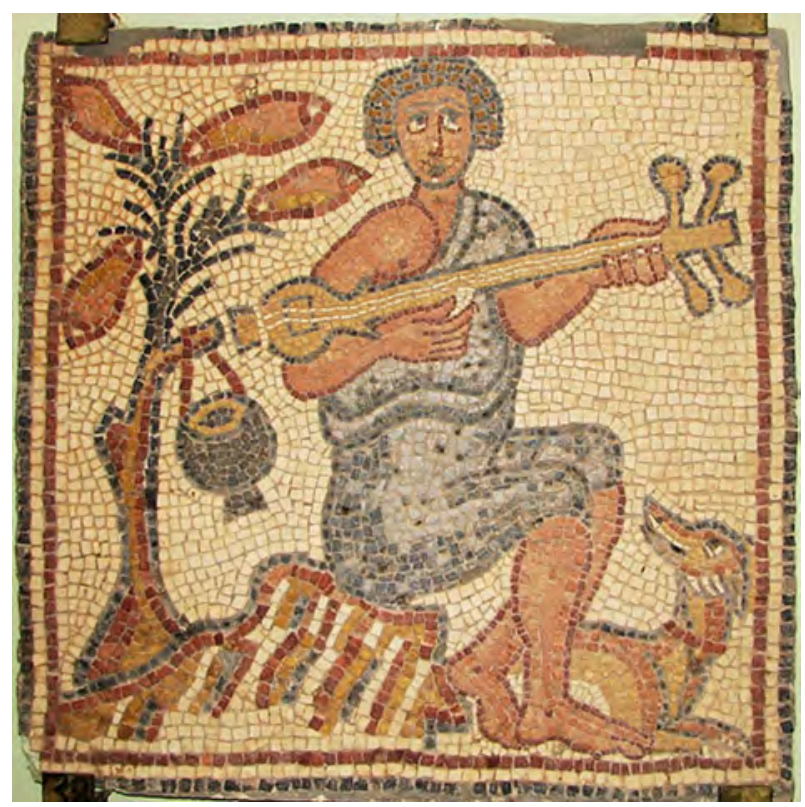

Lám. 13. Mosaico de la basílica de Qasr Lybia. Norte de África, siglo vi.

la caja es un tanto rectangular y abombada, con hombros perpendiculares al mástil y con pequeńos orificios que dibujan triángulos en la tabla de armonía tanto cerca de los hombros como en su parte central, lo que apunta a la piel como su material de construcción. Tiene solo tres cuerdas, que pasan por una varilla cordal y se anudan a una protuberancia al final de la caja. Son punteadas por un grueso plectro que asoma por la mano del tańedor. Se trata de la pandoura, el antiguo instrumento griego de largo mástil que encontramos por primera vez en manos de una musa en un altorrelieve helenístico de Mantineia del 330-320 a.C. (Museo Arqueológico de Atenas), muy difundido por internet. Después de nueve siglos, estos cordófonos de largo mango pervivían, al parecer, en el ámbito bizantino, aunque no encontremos otros ejemplos suyos en el arte. En cambio, sí que aparece otra tipología de caja pequeña en una zona bien alejada de Constantinopla. Se trata de un cordófono con estrechamiento en el final de la caja y hombros que configuran ángulos agudos con el ancho y largo mástil. Tiene cuatro clavijas y un puente en la caja, por el que pasan las dos únicas cuerdas que se han dibujado sobre ella. Aquí también es un pastor con un perro echado a sus pies quien lo tañe (lám. 13). Este curioso instrumento que he homologado a los aparecidos en el Beato de Gerona (fol. 196v. ${ }^{\circ}$ ), códice elaborado en el scriptorium del monasterio zamorano de San Salvador de Tábara en 975, se encuentra en un mosaico de la basílica de Qasr Libya, también del siglo vi, ciudad de la región Cyrenaica, en el norte de África, que fue devastada por los vándalos y refundada en el 539 por Justiniano. 


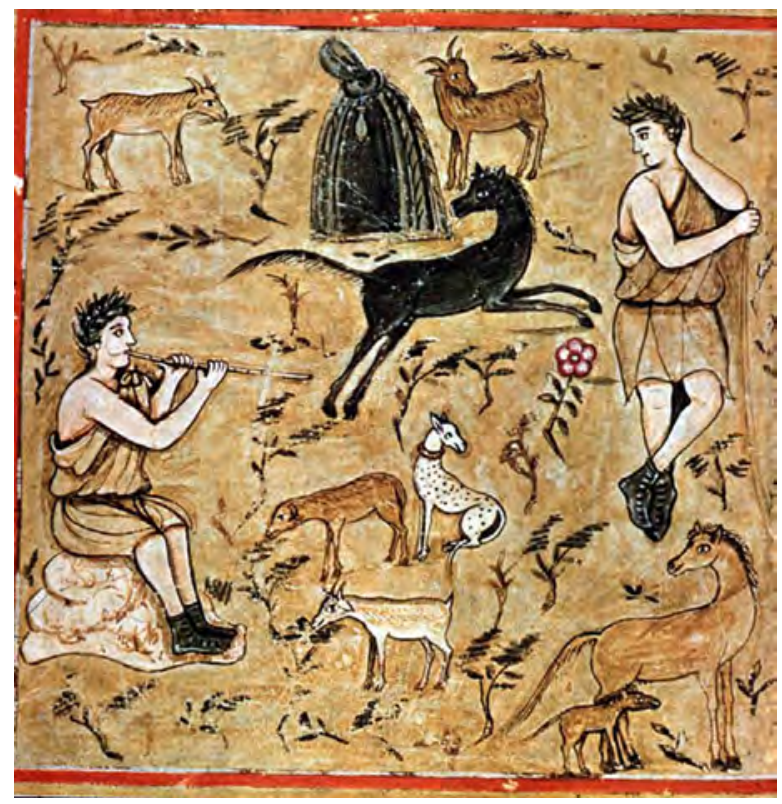

Lám. 14. Églogas de Virgilio. Códice del siglo v. Biblioteca Vaticana, ms. cod. lat. 3867, fol. 44v.․․

En honor a su esposa la ciudad pasó a llamarse Theodoureas, lo que da idea de la importancia que llegó a tener. Los mosaicos son posteriores a este hecho, por lo que su cronología apunta a los ańos cuarenta o cincuenta de ese siglo. De esta manera, se puede apreciar cómo dentro del Imperio bizantino, tan expandido, era lógico que se cultivaran distintas tipologías de cordófonos, máxime siendo instrumentos tan endebles, que posiblemente serían construidos por los propios pastores o por artesanos locales habilidosos que no se adaptaban a plantillas tipificadas.

Pero a los pastores no solo se les muestra con estos cordófonos, también existen imágenes suyas con los tradicionales aerófonos de caña, tipo clarinete. Así los vemos en dos miniaturas del códice que contiene las Églogas de Virgilio (siglos v-vi), Biblioteca Apostólica Vaticana, ms. lat. 3867, fols. 1r. ${ }^{\circ}$ y 44v. ${ }^{\circ}$ (lám. 14). En ambos folios el pintor tuvo buen cuidado de mostrar no solo que los tubos eran de caña por la división del tubo en tramos según los nudos de la planta, sino también que los carrillos del intérprete se inflaban por el esfuerzo que hacía al soplar por el tubo, lo que apunta a la existencia de una lengüeta muy sencilla practicada en la propia caña, que naturalmente con su soplo tenía que hacer vibrar. Son los típicos caramillos que a lo largo de la historia vemos en manos de estos pastores para solazarse en las largas horas de aislamiento en el campo mientras el ganado pastaba.

Y saltando de siglo, nos vamos de nuevo a la época del emperador Heraclio y a unas bandejas de plata elaboradas en Constantinopla entre el 613 y el 629, que se conservan hoy en el Museo de Chipre (Departamento de Antigüedades), en Ni- 


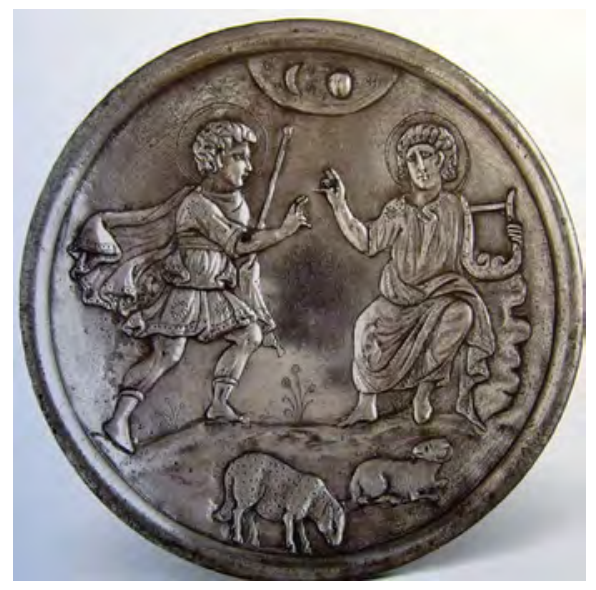

Lám. 15. Plato de plata del siglo vir con David y el mensajero. Museo de Chipre. Nicosia.

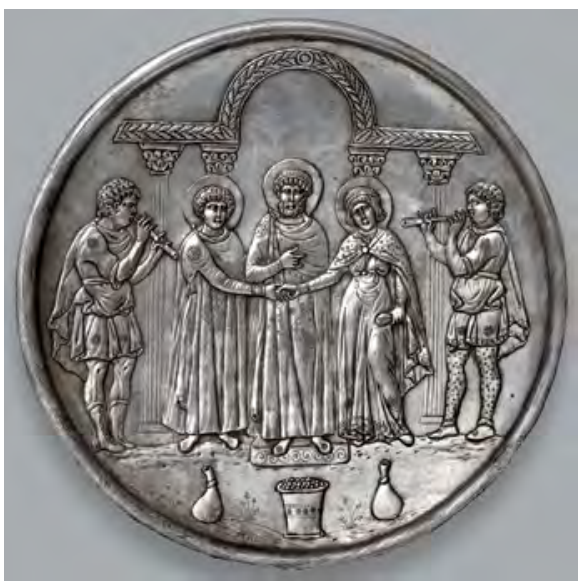

Lám. 16. Plato de plata del siglo vir. Museo de Chipre. Nicosia. Departamento de Antigüedades. Inv. núms. J.452-54.

cosia. Ambas muestran escenas de la vida de David, extraídas del primer libro de Samuel: la primera (lám. 15) ha escogido la escena en que el profeta, muy joven, está cuidando de su rebaño en el campo y a él se dirige un mensajero de Saúl, que viene a buscar al hijo de Jesé para llevarlo de músico a la corte con el fin de que calme el "mal espíritu» que se había apoderado del rey ${ }^{46}$. David, que estaba tañendo la lira en el monte aparta de ella su brazo derecho para saludar al recién llegado, a quien mira con ojos de extrañeza.

El cordófono que se muestra aquí tiene formas muy simples y cuatro cuerdas, y está apoyado sobre una roca. Es esta la primera imagen que nos encontramos de David en el arte bizantino y debemos constatar que la interpretación que se hace del instrumento que tañe el futuro rey bíblico es la correcta, pues el término hebreo kinnor, que aparece en ese texto bíblico, alude a una pequeña lira y no al arpa o a cordófonos frotados como se ve en otras imágenes del propio arte bizantino o del occidental. El segundo plato (lám. 16) representa la boda de David con Mical, la hija de Saúl (Samuel I, 18, 20-27). Y para este acontecimiento feliz, los plateros introdujeron en la escena, flanqueando a la pareja, que es bendecida por el rey Saúl, a dos músicos que soplan unos aerófonos posiblemente de doble lengüeta y de tubo cónico.

Son ya modelos nuevos, que indican que el viejo aulós había caído en desuso. La escena tiene de fondo una arquitectura muy simple de frontón con arco de medio punto sostenido por cuatro columnas de capiteles corintios, que crea un ambiente

46 Libro I de Samuel, cap. 16, 14-23. Lo incluye E.R. Panyagua en su artículo «El influjo de la figura de Orfeo en la iconografía de David músico». Helmántica, vol. 45 (1994), pp. 331-338. 
solemne de carácter palacial. Música, pues, para una boda real acompañada por aerófonos tipo oboe.

Después de este recorrido por las imágenes musicales que nos han llegado de esta etapa, podemos ver que, a pesar de que son muy pocos ejemplos, sin embargo, el abanico de escenas de la vida cotidiana en sus diversos ámbitos sociales y geográficos es amplio: un banquete regio e intérpretes femeninas ofreciendo una audición musical de tipo doméstico en Siria, las carreras en el hipódromo presididas por el emperador en Constantinopla, el mundo del teatro ciudadano con sus pantomimas y mimos, pastores-músicos con sus rebaños en áreas campestres del norte de África y del entorno de la metrópoli, danzas orgiásticas en Jordania con protagonistas femeninas y boda real atemporal con músicos cortesanos. En todas ellas sus intérpretes son seres humanos de carne y hueso, hombres y mujeres que muestran la forma de ejecución del instrumento que llevan entre sus manos o los movimientos de la danza. Pero también hacen música las musas, el dios Apolo y ya más tarde el rey David, que será el intérprete omnipresente en la iconografía musical de los períodos posteriores. Para el artista de ese tiempo todo era digno de ser representado en las obras artísticas con el objetivo de mostrar parcelas de su entorno que permanecieran en la memoria de los hombres, criterio bien distinto de lo que va a suceder a partir de ahora.

Pero antes de entrar en el estudio de las imágenes musicales de los períodos en que gobernaron las dinastías de los Macedonios (867-1057), Comnenos (10811185) y Paleólogos (1261-1453), debemos explicar las razones que condujeron a los artistas plásticos a no introducir personajes con instrumentos musicales ni escenas de danza en sus obras, de ahí la escasez de fuentes iconográficas musicales.

\section{PRINCIPIOS DOCTRINALES QUE OPERARON EN EL ARTE RELIGIOSO BIZANTINO Y QUE AFECTARON A LA ICONOGRAFÍA MUSICAL DEL IMPERIO}

Tras la época de esplendor del arte bizantino durante el reinado de Justiniano (527-565), que se prolonga a las de sus sucesores más inmediatos, hasta la época del emperador Heraclio en el siglo viI (610-641), las artes figurativas bizantinas sufren una gran regresión debido primordialmente a la querella iconoclasta. Esta regresión coincide con la que venía padeciendo la Europa occidental (salvo en parte las Islas Británicas) desde hacía ya un par de siglos tras la caída del Imperio romano, de tal manera que los historiadores del arte han calificado estas centurias como las dark ages ("época oscura»), en la que las actividades artísticas descendieron a un nivel muy bajo ${ }^{47}$.

47 A. Grabar, La Edad de Oro de Justiniano. Madrid, Aguilar, 1966, pp. 337, 340 y 341; y Las vias de la creación en la iconografía cristiana. Madrid, Alianza forma, 2008 (1. ${ }^{\mathrm{a}}$ ed., 7. ${ }^{\mathrm{a}} \mathrm{imp}$. , en adelante, Las vías de la creación), p. 139. 
Después de esta larga etapa de declinación que sufrieron las artes figurativas, la imaginería cristiana resurge por todas partes con gran pujanza, pero las doctrinas sobre la naturaleza de las imágenes religiosas no serán ya semejantes en Oriente y en Occidente, lo que conllevará la adopción de posturas muy diferentes por parte de los artistas frente a la obra de arte, con consecuencias desiguales, a nuestro juicio, en el campo de la iconografía musical.

En el año 843 la emperatriz regente Teodora termina definitivamente con la crisis iconoclasta, que había durado casi un siglo, al reafirmar los principios del segundo Concilio de Nicea (año 787). Con ello, la Iglesia bizantina logró no solo restablecer los iconos, sino que desde el punto de vista ideológico fue mucho más allá en el camino de sus antecesores iconódulos, al formular una nueva doctrina sobre las imágenes y su culto, guiada por el pensamiento de san Juan Damasceno (675749) primero y más tarde por el de Teodoro Studita (759-826), entre otros teólogos. Según esta doctrina, las imágenes de Cristo, la Virgen, ángeles, santos y profetas llevan en sí mismas algo de la naturaleza divina de Jesús o de la gracia y santidad de los restantes personajes sagrados, es decir, algo de su esencia sobrenatural, y esto era precisamente lo que justificaba la veneración y el culto que se les debía, prescindiendo de su parte material ${ }^{48}$. Esta idea incidía de lleno en las artes plásticas, al propiciar la elección de un estilo grave y majestuoso, no exento de hieratismo en las actitudes y en los gestos, acompañado del abandono de la plasticidad en los cuerpos y en las cosas, y con ausencia de espacio y de movimiento ${ }^{49}$. Se suprimía todo aquello que fuera superfluo para la comprensión del mensaje. Nada más impensable, pues, para la mentalidad bizantina que la representación de santos o ángeles músicos adorando a Cristo o a la Virgen con instrumentos musicales, como se observa en el Occidente europeo en las portadas de las catedrales e iglesias de la plena y baja Edad Media o en los retablos góticos. El instrumento musical está ausente de los grandes mosaicos y frescos que recubren por medio de una ordenación simbólica los muros interiores de los templos bizantinos, ordenación simbólica que se había ido gestando desde el siglo vir bajo la influencia de los Padres de la Iglesia griega ${ }^{50}$, y a su vez inspirados por los escritos sobre la "Jerarquía celestial» del Pseudo Dionisio Areopagita ${ }^{51}$, y que había de permanecer casi inamovible durante siglos. Cuando hacen acto de presencia los ángeles y santos en estas composiciones se les representa por lo común con las manos abiertas en seńal de adoración o portando algún libro, rollo o la cruz, e incluso en ocasiones van con las manos cubiertas por velos en actitud venerante hacia la figura divina que preside la composición.

${ }^{48}$ Hasta los cantores que forman parte de composiciones religiosas en el período Paleólogo participan del carácter sagrado de los personajes divinos centrales. Cfr. N.K. Moran, op. cit., p. 5.

49 A. Grabar, Las vías de la creación, pp. 144 y 145.

50 Ch. Dienl, Manuel d'Art byzantine. Vol. II. París, A. Picard, 1925-1926, pp. 486 y 495. Nueva edición de Nabu Press, también en francés, de 2010.

51 W. Sas Zaloziecky, «Arte bizantino». Historia del Arte universal 8, Bilbao, Moretón, 1967, p. 78. 
Hay que añadir, además, que los temas plasmados en mosaicos, frescos y marfiles, no así los de las miniaturas, que encierran, como es obvio, una temática más amplia, son muy limitados, ya que en ellos se evoca esencialmente a Dios, su reino, sus grandes servidores y su historia, es decir, aquellas realidades inmutables para el cristiano, suprimiendo todo comentario a la realidad ideal tal como evidencian las Escrituras $^{52}$. Los artistas tenían que atenerse al programa impuesto por la jerarquía eclesiástica, basado en reafirmar la permanente presencia de Cristo, de los santos o de los acontecimientos de la Salvación, según especificaba el tratado Hermeneia, escrito en la segunda mitad del siglo Ix, lo que dejaba muy poco espacio a la libertad individual $l^{53}$, y es esta la razón por la que el elemento anecdótico o la realidad material no tenía cabida en este tipo de composición teológica. Y aun cuando fuesen el emperador, la emperatriz y su corte los protagonistas de las creaciones plásticas, las obras de arte seguían manteniendo un carácter eminentemente religioso, con rasgos similares a los ya descritos, en tanto en cuanto a aquel se le consideraba el representante de Dios en la tierra. Consecuentemente, las artes plásticas bizantinas no tienen para nosotros un gran valor como fuente de información de la realidad cotidiana ${ }^{54}$.

Es cierto que en el «renacimiento paleólogo» el estilo se dulcifica y se humaniza, que hay un mayor movimiento en las figuras y expresividad en los rostros y que muchas composiciones se pueblan de personajes, pero el contenido y el carácter de estas se mantiene dentro de la tradición bizantina, por lo que los ángeles cuando se representan no ejercen nunca la función de músicos, como sucede en las múltiples tablas de temas marianos o hagiográficos del arte occidental coetáneo, sino que cumplen otras funciones, exceptuando la función de trompeteros en las escenas del Juicio Final, misión que también realizaban en las versiones occidentales de esta temática. Un ejemplo de esto podemos verlo en las pinturas de la bóveda de la catedral de San Demetrio, en la antigua Vladimir-Súzdal, hoy Vladimir, donde se representan ángeles trompeteros en una fecha tan temprana como 1195, realizadas por artistas griegos y rusos. Se trata de «La entrada de los justos en el Paraíso" ${ }^{55}$, un tema afín al Juicio Final. Y esto se realiza en una zona bien alejada de la capital. Volveremos a esta idea más adelante.

Así pues, debemos concluir que mientras el ángel es en Europa el intérprete musical predilecto de los artistas, ya que casi el noventa por ciento de los instrumentos representados en la plástica bajomedieval son ejecutados por ellos, en Bizancio, imbui-

52 A. Grabar, Las vías de la creación, p. 145.

53 Se han conservado dos guías de pintores: una de ellas es la mencionada Hermeneia, cuyo original desapareció, pero sí se conserva una copia del siglo xix inserta en un manuscrito de un monasterio del monte Athos, donde se precisa la manera de representar las escenas del Antiguo Testamento, las doce fiestas mayores del Ańo litúrgico, los Concilios y las escenas hagiográficas, además de indicar el lugar que debía ocupar en el conjunto decorativo del templo cada composición. Cfr. H.W. Haussig, Histoire de la Civilisation Byzantine. París, Librairie Jules Tallandier, 1971 (2. ${ }^{a}$ ed.), p. 98.

${ }_{54}$ A. Grabar, La peinture bizantine. Ginebra, Skira, 1953, p. 21.

55 V. Lazarev, Old Russian Murals and Mosaics, from the XI to the XVI Century. Londres, Phaedon Press, 1966, p. 86, lám. 65. 
dos de otra mentalidad y bajo otras influencias, los pintores, musivarios y eborarios no conciben a estos personajes celestes con un instrumento musical en las manos.

Por otra parte, en las imágenes narrativas de los períodos medio y tardío del arte bizantino, la incidencia de las teorías bizantinas sobre el valor religioso de las representaciones figurativas fue menos acusada. Esas imágenes que ilustraban los libros de los Evangelios y del Antiguo Testamento, canónicos y apócrifos, así como diferentes hagiografías, procuraban seguir literalmente el texto, sin introducir ningún tipo de comentario visual paralelo al literario, al que eran muy aficionados los teólogos, liturgistas, predicadores y poetas ${ }^{56}$. Es aquí donde encontramos algunas de las pocas imágenes instrumentales del arte bizantino, ya que, siguiendo esta tendencia, aquellos pasajes del Antiguo Testamento ilustrados en los Octateucos griegos que citan instrumentos musicales son representados con ellos, como sucede con los cuernos (shofarin) en la toma de Jericó (Josué 6, 4) o el pandero de Míriam y las muchachas que danzan con ella tras el paso del mar Rojo (Éxodo 15, 20). Aquí es curioso constatar que en lugar del pandero la mayoría de las veces se introducen campanas o címbalos, idiófonos de metal entrechocado más comunes en la música bizantina que el membranófono citado por el texto bíblico.

Asimismo, aparecen algunos instrumentos en las ilustraciones del Libro de Job, que en las tradiciones apócrifas también los mencionan, y en los comentarios del Pseudo-Nonnus, que se adjuntan a los libros que contienen las Homilías de san Gregorio Nacianceno, como en el códice Taphou 14 de la Biblioteca del Patriarca griego de Jerusalén. En este manuscrito se representan los instrumentos musicales, allí donde el texto los cita con relación a mitos antiguos y para condenar su práctica. Por el contrario, escenas como las de la Natividad, diversos momentos de la Pasión de Cristo o la Asunción, a las que el artista occidental añade con toda libertad y con bastante frecuencia pastores músicos, juglares, heraldos y ángeles músicos, respectivamente, en el arte bizantino carecen de toda alusión a la música, siendo así que muchas de las fórmulas iconográficas de esta imaginería narrativa bizantina, cuyo núcleo se creó a finales de la Antigüedad, fueron recogidas por los artistas occidentales $^{57}$. Estos repitieron con éxito los modelos griegos y los enriquecieron con elementos ajenos al relato evangélico, como ocurre entre otras cosas con los instrumentos musicales.

Sin embargo, un caso diferente y singular es el de las ilustraciones de los Salmos, que, aunque incluidos en la Biblia canónica, constituían un libro individualizado al igual que los Evangelios, ya que desempeñaban un papel primordial en el Oficio divino de los monjes y en la piedad de los fieles, lo que condujo a la realización de numerosos ejemplares, casi siempre muy ilustrados.

Los Salterios, al ser una colección de poemas (plegarias atribuidas al rey David), a los que se añadían las Odas extraídas de los dos Testamentos, imposibilitaban la utilización de una iconografía descriptiva, tal y como se acostumbraba a hacer

\footnotetext{
56 A. Grabar, Las vías de la creación, pp. 151 y 152.

57 Ibidem.
} 
en otros textos. Por ello, los miniaturistas optaron por seguir tres vías diferentes, según ha especificado André Grabar ${ }^{58}$. La primera, utilizada sobre todo por los iluminadores de talleres imperiales, era la de ilustrar la vida del autor de los Salmos, el rey David, especialmente en su faceta de músico, tañendo algún cordófono (lira o cítara, arpa, salterios simbólicos o reales, instrumentos de arco, etc.), como en uno de los Salterios de la Biblioteca Nacional de París (ms. griego 139), procedimiento este presente sobre todo en los códices llamados aristocráticos. En la segunda vía se recurría a la imagen narrativa cuando el texto evocaba abiertamente o de forma implícita algún hecho de la historia bíblica, añadiendo numerosos retratos de David, opción no demasiado extendida. Y el tercer camino consistía en comentar visualmente por medio de un tema evangélico -Anunciación, Crucifixión, Ascensión, etc.- un versículo de un salmo, tal y como podía ser vislumbrado por los exégetas cristianos (Salterio Khludov, por ejemplo). Incluso, estas imágenes-comentarios podían evocar relatos hagiográficos o la historia reciente de la Iglesia griega. Se abandonaba así la costumbre bizantina y se recurría a un procedimiento similar al usado por los artistas coetáneos occidentales.

Todo esto viene a demostrar que para ilustrar los Salterios el artista bizantino procedía con una libertad inusual de la que carecía al ilustrar otros textos; y no es casualidad que sea precisamente en estos libros donde se encuentre la mayoría de los instrumentos musicales que nos ofrece el arte bizantino, máxime requiriéndolo el tema. Además, resulta curioso observar que muchos Salterios en los que aparece David con un instrumento y rodeado por sus cuatro músicos (Asaph, Ethan, Eman e Idithum) o la profetisa Míriam danzando y cantando con címbalos o con campanas después del paso del mar Rojo (en aquellos salterios en los que se incorporan los cánticos del Antiguo Testamento como este del Éxodo 15) procedan de talleres monásticos de áreas alejadas de la capital, donde la impronta oficial era menos acusada. Así sucede con uno de la segunda mitad del siglo IX del monasterio de Cristo Pantokratoros 61 en el monte Athos, fol. 206, que posiblemente proceda de un taller monástico de Asia Menor ${ }^{59}$, y con otros más tardíos del mundo eslavo (Salterios del Museo de la Historia de Moscú, ms. 3, siglos XIII-XIV y ms. 2752 de la segunda mitad del siglo XIv; y Salterio de Munich, Staatbibliothek, slav. 4, ca. 1400). Quizás podríamos añadir a este grupo el famoso Salterio griego 752 de la Biblioteca Vaticana, del siglo XI (fols. 3r. ${ }^{\circ}, 5 \mathrm{r}^{\circ}, 7 \mathrm{v} .^{\circ}, 18 \mathrm{v}^{\circ}, 23 \mathrm{v}^{\circ}, 448 \mathrm{r}^{\circ}, 449 \mathrm{r}^{\circ}$ y $449 \mathrm{v} .^{\circ}$ ), que proviene del monasterio griego de Pantanassa, en el Peloponeso, aunque se ignora su lugar de ejecución ${ }^{60}$.

E incluso, ilustraciones de los tres últimos salmos llamados Ainoi o Pasa Pnoe, es decir, salmos de alabanza a Dios, que rara vez aparecen en las decoraciones murales

58 Ibidem, pp. 156 y 157.

59 T. SeEbass, Musikdarstellung und Psalterillustration im früheren mittelalter. Berna, Francke Verlag, 1973, p. 175 y lám. 86.

${ }^{60}$ Ibidem, p. 185, láms. 84 y 85; W. Bachmann, The Origins of Bowing..., p. 36 y láms. 5 y 7, en Biblioteca Vaticana, Madrid, Encuentro, 1987, p. 94 se indica sin una argumentación sólida que, quizás, pudo haber sido miniado en Constantinopla. 
de las iglesias bizantinas, a pesar del peso tan importante que tenía la salmodia en la liturgia oriental, se pueden ver decorando las paredes de las iglesias macedonias de los monasterios de Lesnovo y de Kuceviste, ya a mediados del siglo xiv. En ellas se incluyen cantores e instrumentistas, estos últimos sobre todo en la visualización del Salmo 150. Pese a que esta representación ha desaparecido de la iglesia de Lesnovo, no ha sucedido así con la de la iglesia de El Salvador de Kuceviste, en cuyo nártex se aprecian unos frescos muy deteriorados con músicos que tañen un laúd, un salterio trapezoidal y dos trompetas, rodeando a un grupo de cantores ${ }^{61}$. Esto corrobora que los artistas en esta época tardía, en la que Macedonia había pasado al poder de los turcos otomanos y había dejado de estar sujeta a las directrices de Bizancio, tenían una mayor libertad para introducir modificaciones en las pinturas de temas cristianos, que incluían asimismo la utilización de instrumentos del mundo musulmán, pero, eso sí, siempre que el texto a ilustrar lo permitiera o lo exigiera. Nunca como algo anecdótico.

Y efectivamente, las pinturas que decoran las iglesias de estas áreas balcánicas, una vez que se segregan del Imperio bizantino en el período paleólogo, introducen variados instrumentos musicales en diferentes temas, como algunos del rey David, lo que ya era usual en la miniatura del período anterior, y otros cristológicos, empezando por el de las burlas a Cristo en el pretorio. Esta es una temática que nace y se desarrolla en estas áreas geográficas de los Balcanes y que también se exporta a Occidente, como más adelante se verá. Existen varios trabajos de investigadores del área balcánica sobre estas mencionadas pinturas tardías, cuya cronología se extiende desde mediados del siglo XIv hasta mediados del siglo XVIII, como los de Ion Solcanu $^{62}$ y Anca Florea ${ }^{63}$, o los citados de Roksanda Pejovic y Gabriela Ilnitchi Currie.

En otro orden de cosas, pero siempre dentro de un contexto religioso y también alejadas de la capital, estarían las pinturas al fresco de las escaleras de las torres que conducen a la galería alta en Santa Sofía de Kiev, realizadas durante el reinado de Vladimir Monomaco (1113-1125), y no un siglo antes, en la época de Yaroslav, como siempre se había pensado erróneamente, que fue cuando se erigió y decoró la mayor parte de este edificio ${ }^{64}$. En la escalera de la torre suroeste están pintadas algunas de las actividades que se practicaban en el hipódromo de Constantinopla,

${ }^{61}$ N.K. Moran, op. cit., pp. 89-91 y lám. 56.

62 I. Solcanu, "Les instruments de musique dans la peinture murale de Pays Roumains (XIV-XVII siècles)». Revue des archéologues et historiens d'art de Louvain, vol. 12 (1979), pp. 120-48.

63 A. FloreA, «String instruments in Romanian mural paintings between the 14th and 19th centuries». RIdIM Newsletter, vol. 19, núm. 2 (1994), pp. 54-65; y «Wind and percussion instruments in Romanian mural painting». RIdIM Newsletter, vol. 22, núm. 1 (1997), pp. 23-30.

${ }^{64}$ Aunque se había creído durante mucho tiempo que los frescos de las torres eran coetáneos del resto del edificio, hipótesis artística que había sido recogida por algunos musicólogos como Tilman Seebass, estudios arquitectónicos posteriores, como los de N. Kresal'Ny, Sofiyskiy Zapovednik v. Kieve. Kiev, 1960, p. 233; y M. Karger, Drevniy Kiev, vol. II, Mosow-Leningrad, 1961, pp. $157-$ 175 , han demostrado que los cuerpos de las torres fueron construidos un siglo más tarde, durante el reinado de Vladimir Monomaco. A esta conclusión también han llegado otros historiadores del arte, al analizar el estilo de los frescos que las recubren en su interior. Cfr. V. LAZAREv, op. cit., p. 56. 
que son contempladas por el emperador bizantino y su corte desde la galería del palacio Kathisma ${ }^{65}$. Junto a estas escenas aparecen otras de cacería y un conjunto de mimos danzando, mientras unos músicos tañen sus instrumentos, personajes que también pueden verse en las pinturas de la torre noroeste. Es, naturalmente, una temática desusada para el interior de un templo, que se aparta en estos frescos del riguroso orden preestablecido tradicionalmente, por lo que se le destina un lugar menos visible y frecuentado.

¿Se podría establecer aquí un paralelismo de propósitos, o de permisividad si se quiere, salvando la distancia espacial y temporal, entre el príncipe ruso Vladimir Monomaco (1113-1125), al ordenar este tipo de pinturas en el interior de un recinto religioso, y el rey normando Roger II (1130-1154) de Sicilia, al permitir una temática profana en las decoraciones pictóricas de los múltiples alvéolos del techo de la Capilla Palatina de Palermo? Aunque esta última obra fue realizada por musulmanes, quienes reprodujeron en ellas escenas de batalla y de caza, animales fantásticos y reales, gran variedad de músicos, textos y arabescos, el resto del templo fue decorado por musivarios griegos, que se adaptaron a la estricta ordenación temática de tipo bizantino ${ }^{66}$, al igual que ocurría con los mosaicos y pinturas de naves, ábsides, bóvedas y capillas de Santa Sofía de Kiev. Sin embargo, en ambas iglesias y en zonas poco visibles para el clero y los fieles se plasman temas profanos, en los que hace acto de presencia la música. La explicación habría que buscarla en el significado de estas pinturas. En ambos casos constituían un símbolo de la grandeza y del poder del monarca reinante en cada territorio ${ }^{67}$, aunque diferían en algunos aspectos de su temática y, sobre todo, en su estilo y su presentación.

En el primer caso, Vladimir Monomaco, admirador del mundo griego por ser hijo de una princesa bizantina, permite a sus pintores locales escoger escenas características de los dípticos consulares griegos y de las decoraciones de los palacios imperiales, posiblemente bajo la guía de su propia madre ${ }^{68}$. Y, aunque en ellas aparezca el emperador bizantino ${ }^{69}$, en realidad lo que quieren manifestar es el poder del gran príncipe de Kiev, e incluso las escenas de caza, que constituyen otra variante del motivo de triunfo ${ }^{70}$, están dentro de esta tendencia.

${ }^{65}$ A. Grabar, «Les fresques des escaliers à Sainte-Sophia de Kiev et l’iconographie imperiale byzantine». Seminarium Kodakovianum, vol. viII (1935), pp. 192-197.

${ }^{66}$ Roger II se dejó seducir por el ceremonial de la corte bizantina e incluso se hizo representar en los mosaicos de Santa María del Almirante coronado por Cristo, al igual que un basileus bizantino.

${ }^{67}$ V. Lazarev, op. cit., p. 57; y D. Gramit, The Music Paintings of the Cappella Palatina in Palermo. Imago Musicae, vol. II (1985). Basilea, Bärenreiter-Verlag, 1986, pp. 36 y 37.

${ }^{68}$ Se conservan algunas descripciones de estas pinturas, como las del palacio de Andronico Comneno, con escenas de caza y del hipódromo, aunque no se detalla la presencia de la música. Cfr. V. Lazarev, op. cit., pp. 57, 237 y 240.

${ }^{69}$ A. Grabar, «Les fresques des escaliers à Sainte-Sophia de Kiev et l'iconographie impériale byzantine», pp. 102-117; y L'empereur dans l'art byzantin. París, Les Belles Lettres, 1936, pp. 62-74 y $144-147$.

${ }^{70}$ V. Lazarev, op. cit., p. 57. 
Por su parte, el rey normando Roger, en otro contexto cultural y religioso, pero con un predominio de lo bizantino en la decoración de sus iglesias, consiente en que el equipo de pintores musulmanes exprese lo mismo que las pinturas de Kiev por medio de una gran cantidad de personajes aislados ${ }^{71}$ o en parejas situados en los alvéolos del techo de su capilla. Estas escenas con bebedores, músicos y cazadores son, posiblemente, similares a las realizadas por un artista persa en la sala Mouchroutas, situada al oeste del Chrysotriclinium en el palacio imperial de Constantinopla, donde se representaron cierto número de costumbres persas en los alvéolos de su techumbre de madera ${ }^{72}$. Esta temática profana era invisible desde las naves del templo, ya que, dada la pequeñez de las imágenes, el espectador habitual solo podía percibir una abigarrada decoración multicolor, y ello permitía una mayor libertad en la elección del repertorio.

Esa relajación de la práctica y rigor bizantino no nos debe extrañar en dos estados que, aunque bajo la órbita cultural, artística y en diversa medida religiosa del Imperio bizantino, estaban lo suficientemente alejados de Constantinopla como para que su influencia se debilitara y se mezclara con la de otras culturas, que en el caso de Sicilia era la musulmana y la cristiana occidental ${ }^{73}$.

Por ello, pensamos que es necesario buscar fuentes iconográficas para el estudio de los instrumentos musicales bizantinos en el arte de países que sufrieron la impronta política o cultural de Bizancio, pero en los que sus ideas sobre el valor de las imágenes no llegaron a calar hondo. De esta manera, en el arte occidental, especialmente en el italiano, nos encontramos con imágenes musicales, en las que sus instrumentos y combinaciones son claramente griegos y no occidentales, como a primera vista se podría pensar. Así, por ejemplo, una miniatura de un códice del año 1023 conservado en la abadía de Montecassino con el De Universo Libri XXII de Hrabanus Maurus (ms. 1896, lib. XviII, cap. IV, p. 444; lám. 17) exhibe tres músicos tocando unos címbalos, un arpa bizantina, en una interpretación muy peculiar del miniaturista, porque ha dibujado el trigonon de la antigua Grecia, y un laúd corto de clavijero plano, propio de esa área oriental.

En el suelo se encuentra una cítara rectangular, semejante a las que se ven en miniaturas y marfiles bizantinos del siglo x (cajas de rosetas, y miniaturas del códice gr. 139 de la Bibl. Nat. París). También en el retablo italobizantino de la Pasión del Museo Diocesano de Palma de Mallorca, que procede del convento de Santa Clara de la misma población, pintado al temple sobre tabla entre 1290 y

71 Hay quienes piensan que un personaje coronado y sedente del techo puede representar al propio monarca normando. Cfr. «Bizancio y el islam», en Enciclopedia Universal del Arte, vol. Iv, Barcelona, Plaza y Janés, 1978, p. 330.

72 S. Curcic, "Some palatine aspects of the Cappella Palatina in Palermo». Dumbarton Oaks Papers, núm. 41 (1987), pp. 125-144, p. 141. Este autor establece, además, paralelismos entre la estructura arquitectónica de la capilla siciliana y la de varias dependencias del Palacio Imperial de Constantinopla, demostrando que los modelos de Palermo vienen de Bizancio.

${ }^{73}$ La población de Sicilia estaba conformada por griegos y musulmanes primordialmente, a los que se sumaron los normandos en el siglo XI. 


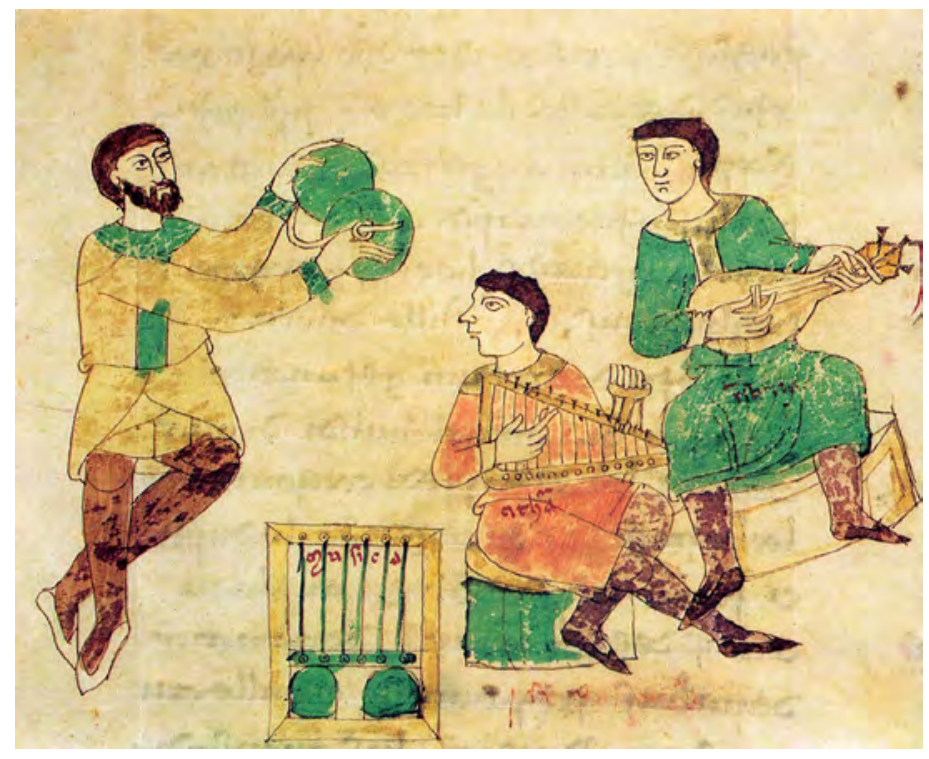

Lám. 17. De Universo de Hrabanus Maurus, ms. 1896, lib. xvin, cap. Iv, p. 444. Abadía de Montecassino.

1305 , se encuentra una escena musical típicamente bizantina. Se trata de la tabla que contiene las burlas a Cristo durante su detención en el pretorio por parte de un grupo de judíos, convertidos aquí en músicos que tañen un arpa-cítara, unos címbalos y una corneta curva. Además, dos danzarines con largas mangas evolucionan en presencia de Cristo ${ }^{74}$.

Todo lo anteriormente expuesto demuestra la limitada incidencia que tuvieron los instrumentos musicales en las artes figurativas de Bizancio y, como consecuencia, la pésima calidad de las escasas representaciones existentes, quizás debido al poco hábito que tenían los pintores de plasmar estos objetos. No muestran sus elementos constitutivos ni sus rasgos esenciales, por lo que a veces nos encontramos con muchas dificultades para determinar la propia tipología del instrumento. Si a todo ello añadimos la mala conservación de muchas iluminaciones, con pérdida de pintura, podremos comprender lo difícil que resulta el estudio de la organología bizantina, lo abandonado que está este campo de la investigación y la importancia de cualquier nuevo hallazgo.

${ }^{74}$ R. Állvarez, «Instrumentos bizantinos en una pintura medieval del Museo Diocesano de Palma de Mallorca», en "De Musica Hispana et aliis", Miscelánea en honor al profesor Dr. José LópezCalo, vol. I, Universidad de Santiago de Compostela, 1990, pp. 43-53. 


\section{LA VARIADA TEMÁTICA DE LAS IMÁGENES MUSICALES EN LA SEGUNDA Y TERCERA EDAD DE ORO}

Con estos presupuestos veamos ahora lo que nos muestran las imágenes sobre el mundo musical bizantino de la segunda y tercera Edad de Oro, centradas en los períodos en que gobernaron las dinastías de los Macedonios (siglos IX-XI), Comnenos (siglos XI-XII) y Paleólogos (siglos XIII-XV). Y para ello tenemos que aclarar, ante todo, que la mayoría de las imágenes que hemos podido recopilar de estos siglos se encuentran en las miniaturas de diversos códices, casi todos litúrgicos o con contenido religioso (Salterios, Octateucos, Homilías de san Gregorio Nacianceno y Comentarios del Pseudo-Nonnus), aunque también existen algunos de tipo profano como La Cinegética del Pseudo-Opiano (Opiano de Apamea) y otros que contienen crónicas, como la famosa de Juan Skylitzes de la Biblioteca Nacional de Madrid o aquella de Constantino Manasés de la Biblioteca Vaticana. Salvo los escasos instrumentos musicales tallados en cajitas de marfil de los siglos IX-XI y XV y aquellos pintados en los muros de la escalera de la torre suroeste de la catedral de Kiev, con escenas del hipódromo de Constantinopla, que ya hemos citado, el resto de ejemplos están en miniaturas en las que casi siempre el protagonista es el rey David, tanto en distintos episodios de su azarosa vida como entronizado y tańendo algún instrumento como símbolo de su identidad como rey músico, poeta, presumible autor de los Salmos, liturgista, e incluso como constructor de instrumentos, según lo explicita el salmo apócrifo 151. Aunque no es frecuente, también lo encontramos danzando delante del Arca de la Alianza y, por supuesto, en muchas ocasiones rodeado por sus músicos (Asaph, Eman, Ethan e Idithum). Por tanto, la vida cotidiana que contemplábamos en las imágenes del período anterior brilla por su ausencia en estas miniaturas, excepto las que corresponden a las crónicas. Pero las que sí se multiplican son aquellas de danzas femeninas, porque los Octateucos las incorporan en el libro del Génesis tras la narración del paso del mar Rojo, en la que la hermana de Moisés, Míriam, es la protagonista. De todas formas, sí es verdad que los instrumentos musicales que se representan en todos estos manuscritos son los de la época, salvo alguna excepción que comentaremos. De ahí que sean tan importantes para nuestros fines, porque nos muestran las diversas tipologías instrumentales que se usaron en cada momento.

De este modo, comenzaremos nuestro recorrido precisamente por esas muestras dancísticas, ya que cronológicamente la temática es la más antigua según la Biblia, aunque no lo sean los códices que las contengan. Seguiremos por la toma de Jericó, incluida también en el Génesis, para entrar de lleno en las imágenes del rey David contenidas en los Salterios, que aluden a su biografía tomada tanto del Libro I de Samuel como del de los Reyes I y del de las Crónicas I (15 y 16), que constituyen un núcleo de imágenes musicales muy interesantes, porque es precisamente en estos códices donde se ve una serie de instrumentos musicales nuevos procedentes de otras culturas orientales, que los bizantinos van a asumir como suyos y que permanecerán hasta la actualidad como instrumentos populares en los países que conformaron en el pasado el imperio. Pero, es más, es justo en los Salterios donde también vemos instrumentos característicos del mundo occidental, 
concretamente de las Islas Británicas o de Francia, lo que nos obliga a preguntarnos cómo llegaron estas imágenes a los códices bizantinos, porque la ausencia real de los mismos en esta área geográfica descarta una copia de una realidad circundante. Sin embargo, las influencias más evidentes son las del instrumentario de los distintos pueblos del Cercano y Medio Oriente, como los persas o los turcos, primero los selyúcidas y luego los otomanos, por ejemplo, sin olvidar alguna proveniente del Egipto fatimita.

Asimismo, debemos contemplar el mundo de los pastores, de los que siguen apareciendo algunas imágenes en distintos contextos, o el de la guerra en todas sus manifestaciones, tales como los enfrentamientos de los ejércitos terrestres, los asedios y los ataques fuera de las fortalezas. También son dignos de mención algunos temas de la vida del emperador, como su proclamación, sus viajes, su recibimiento en una ciudad o su presencia en el hipódromo de nuevo. Otros temas contemplados por los artistas son los de las ceremonias litúrgicas dentro de los templos y, por supuesto, el cristológico de las burlas a Cristo durante su Pasión, un tema que, como ya hemos dicho, comienza a desarrollarse en el tardío siglo XIV en los países balcánicos y que va a tener un largo recorrido, convirtiéndose en siglos posteriores en un tema estrella para los estudiosos de la organología postbizantina. Y también haremos alguna mención puntual a algunos temas mitológicos aparecidos en la eboraria del renacimiento macedonio.

\subsection{El ÁMBito RELIGIOSO}

\subsubsection{La danza de Míriam y de las hijas de Israel (Éxodo, 15, 20-21)}

Ya hemos hablado de la importancia que tanto en la Antigüedad como en este período medieval tenían las danzas de mujeres, algo característico de esta zona, pues en la Europa occidental no son tan frecuentes, salvo para narrar la famosa danza de Salomé de los Evangelios sinópticos. Hemos visto danzas en grupos (obelisco de Teodosio) y también individuales, al ritmo de grandes y profundos címbalos, las acetábulas en Madaba (actual Jordania) o de pequeñas campanitas atadas a los extremos de cintas de tela (plato del Ermitage, aunque aquí también danza el Sileno con el cerdo sobre sus hombros) y ahora en el siglo Ix, en el códice Khludov del Museo Estatal de Historia de Moscú (ms. 129, fol. 148v. ${ }^{\circ}$; lám. 18), se representa a Míriam delante de su hermano Moisés, que acaba de entonar su Cántico de alabanza a Dios, y de todo el pueblo de Israel, danzando de forma bastante llamativa, pues lleva los brazos en alto, sobre su cabeza, mientras sacude por el mango unas pequeñas campanas como signo de su regocijo por el prodigio divino que acaba de presenciar. El vuelo de la falda y su melena suelta apuntan a un tipo de danza muy rítmica y de mucho movimiento, característica del mundo oriental.

Algo similar es lo que muestra un códice del monte Athos en el monasterio Pantokratoros (ms. 61, fol. 206), en una de sus miniaturas marginales. Este es un códice un poco más tardío que el Khludov, pues está datado en la segunda mitad del siglo Ix, mientras que el Khludov se cree que fue realizado «a escondidas» en la segunda década de esta misma centuria, en plena crisis iconoclasta. Es uno de los tres 


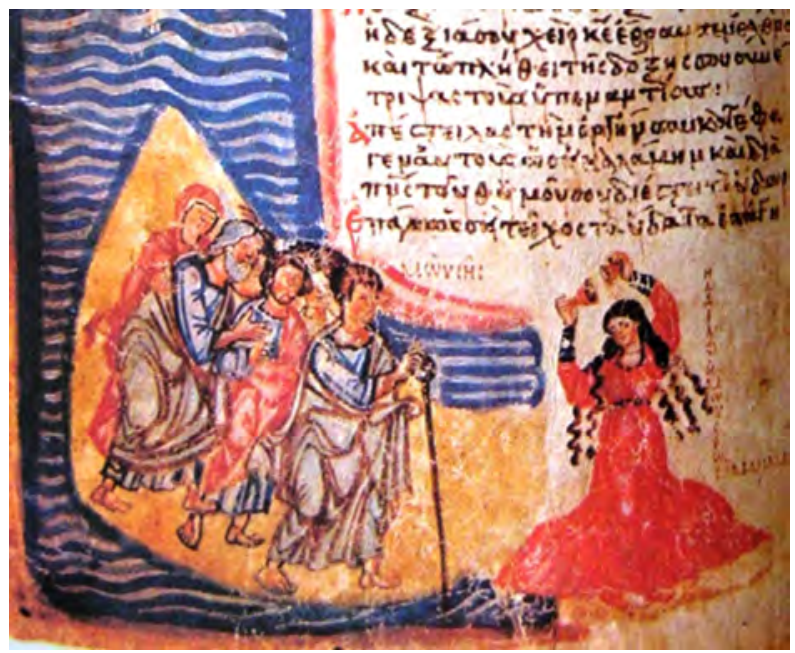

Lám. 18. Míriam danzando tras el paso del mar Rojo, fol. 148v. ${ }^{\circ}$ del Salterio Kchludov, primera mitad del s. Ix. Museo Histórico de Moscú.

códices iconódulos que sobrevivieron a la destrucción del fanatismo iconoclasta ${ }^{75}$. La importancia de este manuscrito, que posee miniaturas marginales, es tal que se ha hecho una edición facsímil para difundirlo y existen páginas web dedicadas a él ${ }^{76}$, aparte del estudio comparativo de sus miniaturas llevado a cabo por Elina Dobrynina tras su restauración ${ }^{77}$.

La danza individual de Míriam al son de campanitas se repite en los códices aristocráticos confeccionados en el scriptorium real de Constantinopla a finales del mismo siglo Ix, como en el famoso Salterio griego 139 de la Biblioteca Nacional de París, fol. 5v. ${ }^{\circ}$ (lám. 19), una magnífica miniatura con influencias de la tardía Antigüedad, en la que los personajes se disponen delante de un fondo de espléndidas arquitecturas clásicas.

Tenemos que aclarar antes de continuar adelante que los códices de los Salterios no solo contenían los 150 salmos (a veces se añadía el salmo apócrifo 151),

75 Hay quienes piensan que se confeccionó en San Juan el Studita o en la propia iglesia de Santa Sofía tras el fin de la iconoclastia, pero Fernanda De' Maffei lo adjudica al área de Palestina y le ha dado una fecha muy temprana: segundo decenio del siglo ix. Cfr. F. De’ Maffei, «Le figurazioni marginali del Salterio Khludov e l'iconoclastia». Beassarione Quaderno, Roma, núm. 41 (1985), pp. 29-95.

${ }_{76}$ https://commons.wikimedia.org/wiki/Category:Chludov_Psalter. http://www.rodon.cz/ ikony/Iluminovane-a-vzacne-rukopisy/Chludovsky-zaltar-1672.

77 E. Dobrynina, «New findings on the Khludov Psalter revealed during restoration, in

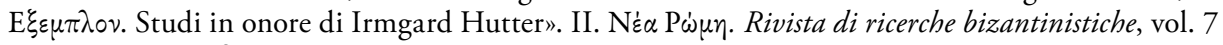
(2011), pp. 1-16, figs. 1-23. 


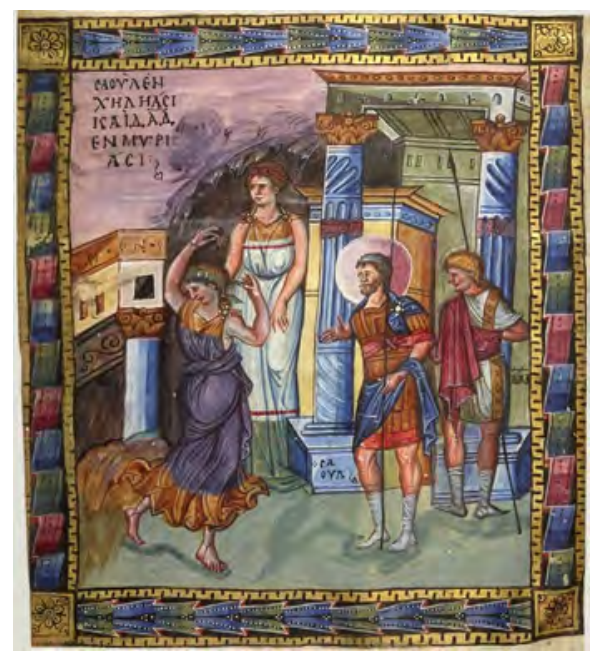

Lám. 19. La danza de Míriam, fol. 5v. ${ }^{\circ}$ del Salterio griego 139.

Biblioteca Nacional de París.

sino que también encerraban las catorce Odas o Cánticos de la Biblia, tanto los del Antiguo como los del Nuevo Testamento, de manera que en ellos estaba presente el Cántico de Moisés del Éxodo 15, 1-19; de ahí que hubiera en ellos miniaturas con la danza de Míriam, que venía a continuación como expresión visual del Cántico. Otro códice aristocrático que la incorpora es el París gr. 510, fol. $164 \mathrm{v} .^{\circ}$, confeccionado también en Constantinopla entre el 880 y 883 para el basileus Basilio I, que encierra las Homilías de san Gregorio Nacianceno, pero la miniatura está tan deteriorada que apenas se puede percibir a la protagonista. No obstante, se vislumbra que la postura de sus brazos es similar a la danzarina del códice Khludov. En esta imagen, además, se ha incluido a los egipcios con sus caballos y sus carros $^{78}$.

Una miniatura de transición entre estas y las posteriores de danzas en parejas la vemos en el Salterio Barberini del año 1050 (Bibl. Vaticana gr. 372, fol. 249 r. ${ }^{\circ}$; lám. 20), en la que Míriam sacude las campanas con los brazos en arco sobre la cabeza, rodeada por cuatro jóvenes instrumentistas que tocan una flauta travesera, un tambor cilíndrico de doble parche con la punta de la baqueta doblada, grandes címbalos y un cordófono de arco con figura entallada y clavijero en canal que se apoya en el hombro, cuyas cuerdas son frotadas por un gran arco en la posición que hoy es usual para estos cordófonos en Europa, adonde llegó como vemos procedente de Bizancio. En la vuelta de este folio aparece de nuevo Míriam de cara a los israelitas, vol. II, p. 87 .

${ }^{78}$ Está reproducida en blanco y negro en la obra ya citada en la nota 57 de T. SeEbass, 


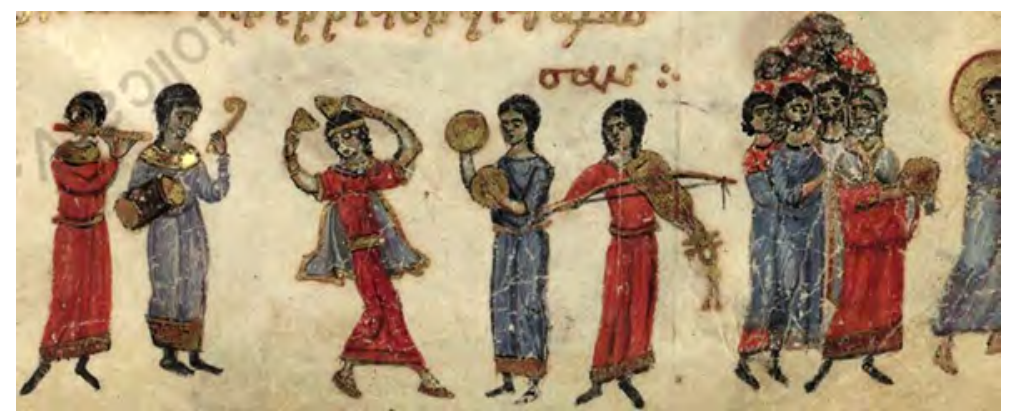

Lám. 20. Danza de Míriam con campanas rodeada de «las hijas de Israel», que tañen diversos instrumentos musicales. Salterio Barberini. Vat. gr. 372, fol. 249r. ${ }^{\circ}$.

con una campana de tamaño mediano en cada mano y sin danzar, a la espera de que estos terminen de cruzar el mar Rojo.

Estas danzas individuales de Míriam desaparecen en el curso de esta centuria en la que finaliza el renacimiento macedonio, no sin antes hacer acto de presencia en un códice de naturaleza diferente como fue La Cinegética del Pseudo-Opiano, de principios del siglo xi (Biblioteca Marciana de Venecia, gr. 479), donde se ve a una bailarina entrechocando címbalos por encima de su cabeza en una fila en la que va precedida por un bailarín con barba que manipula unos crótalos, reminiscencia de los ya vistos en el período anterior, lo que quizás nos indique que ha sido copiada esta imagen de algún códice de la baja Antigüedad, porque ya en el período macedonio había desaparecido este idiófono. Esta es la única figura masculina que nos hemos encontrado en actitud de danzar en esta época.

A partir de estos momentos lo que van a mostrar las imágenes serán danzarinas en parejas o en grupos que vienen a sustituir al personaje bíblico anterior, como signo de colectividad. Existen varias imágenes de pequeños conjuntos de cuatro muchachas, dos danzando en pareja y flanqueándolas instrumentistas de tambor y de campanas. Una de las primeras de este tipo la encontramos en un Octateuco de la Biblioteca Vaticana, cod. gr. 747, fol. 90v. ${ }^{\circ}$ del siglo xi (lam. 21), donde se ha dispuesto a cuatro jóvenes, de las que tres danzan y la cuarta percute un tambor cilíndrico a la izquierda de la imagen.

Las dos danzarinas centrales se cogen de las manos y se contorsionan en pareja con las cabezas hacia atrás y una pierna alzada, mientras que la cuarta se mueve sola sacudiendo unas pequeñísimas campanas. El miniaturista ha tenido buen cuidado en mostrarnos los dos parches del tambor en una perspectiva imposible. Se percuten ambos con una baqueta típica de esta zona que presenta un extremo doblado. Otros ejemplos semejantes, aunque sin las contorsiones de las bailarinas centrales, que bailan ahora más lento, se encuentran en otros dos códices del siglo XII, uno copia del otro. Se trata de los Octateucos de la Vaticana, cod. gr. 746, fol. 194v. ${ }^{\circ}$ (lám. 22) y el de la Biblioteca del Serrallo en Estambul, donde se ha dispuesto asimismo a cuatro muchachas, $y$, al igual que en la miniatura anterior, tres bailan y la cuarta 


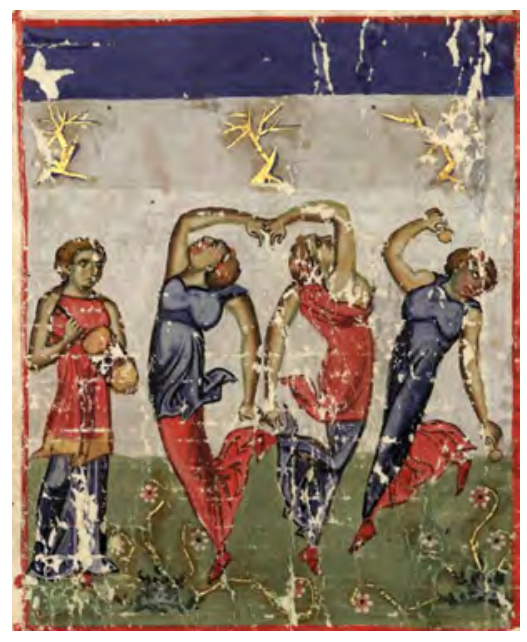

Lám. 21. Danza de «las hijas de Israel».

Octateuco Vat. gr. 747, fol. 90v. ${ }^{\circ}$, siglo xI.

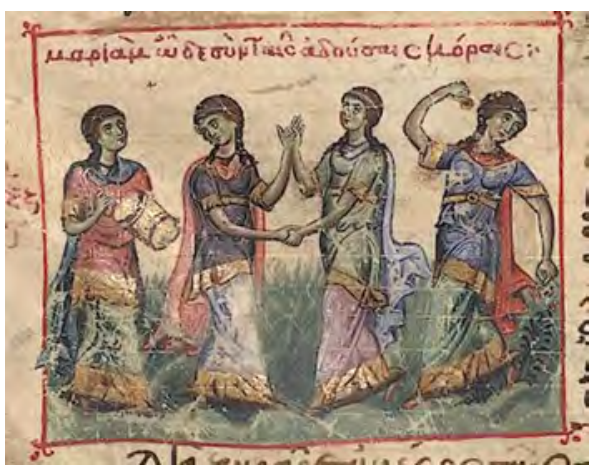

Lám. 22. Danza de «las hijas de Israel». Octateuco Vat. gr. 746, fol. 194v. ${ }^{\circ}$, siglo XII.

percute un tambor de cilindro con una baqueta similar. La joven de la derecha danza también al son de unas pequeñas campanas con movimientos más movidos y las dos centrales se entrelazan las manos enfrentadas ${ }^{79}$. Es muy posible que encontremos escenas similares en otros Octateucos referentes a este mismo pasaje del Éxodo, pero poco podrían aportar a lo ya expuesto y mostrado en estas imágenes.

Aparte de estas danzas en parejas, las miniaturas nos ofrecen también ejemplos de danzas colectivas, unas en rueda y otras en fila. El primer tipo nos lo muestra el Salterio Hamilton a finales del siglo XIII en su folio 243v. ${ }^{\circ}$ (Berlín, Staatliche Museen, Preußischer Kulturbesitz, Kupferstichkabinett 78 A 9; lám. 23), donde un grupo de seis mujeres jóvenes con ricas vestiduras talares de vivos colores danzan cogidas de la mano al son de un aerófono no identificado que sopla un músico fuera del círculo, mientras que en la parte superior Moisés entona su Cántico de alabanza a Dios delante del pueblo de Israel.

Y frente a esta danza concertada y ordenada nos encontramos otra en un Salterio búlgaro de $c a$. 1360, conservado en el Museo Histórico de Moscú, ms. 2752, fol. 249v. ${ }^{\circ}$ (lám. 24), en la que nueve mujeres, también con largas túnicas, algunas sin mangas, pero sí con mantos (uno elevado en círculo sobre la cabeza de la cimbalista), danzan y tañen instrumentos musicales de una forma más caótica, realizando movi-

79 Estas miniaturas las estudié en un artículo sobre la incidencia que tenía para la iconografía musical la copia de códices. Cfr: M.R. Álvarez, «Incidencia de una forma de trabajo en la representación de los instrumentos musicales: la copia de códices en la Edad Media». Nassarre. Revista aragonesa de musicología, vol. 23, núm. 1 (2007), pp. 53-86, láms. 1 y 2. 


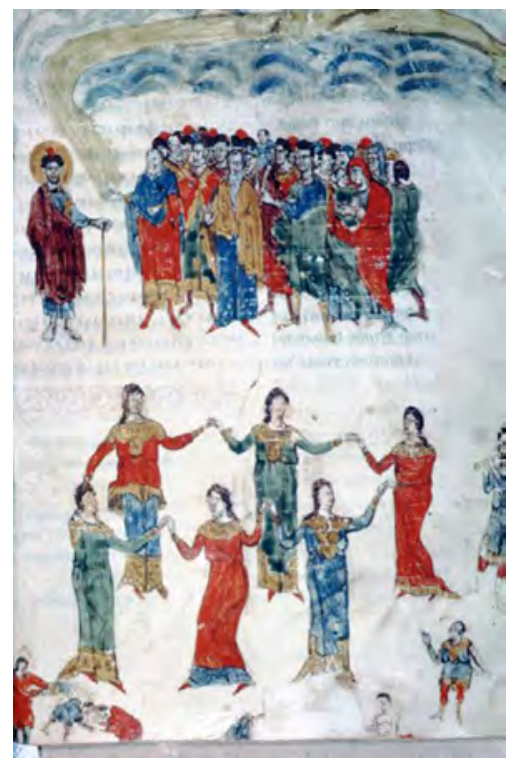

Lám. 23. Cántico de Moisés y danza de «las hijas de Israel». Salterio Hamilton del siglo xiII, fol. 243v. ${ }^{\circ}$. Preussiches Landerbibliothek, Kupferstichkabinett 78 A 9.

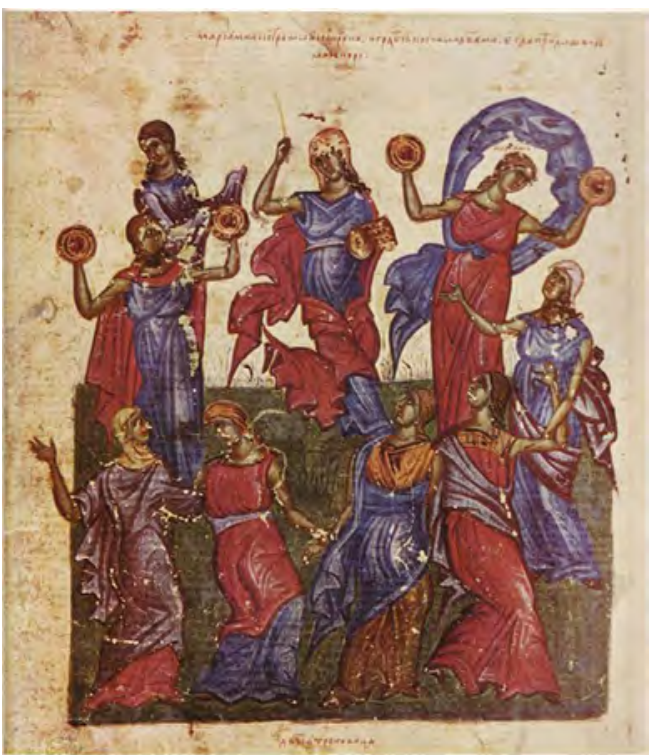

Lám. 24. Danza de Míriam y «las hijas de Israel». Salterio búlgaro de 1360, fol. 249v. ${ }^{\circ}$. Museo Histórico de Moscú, ms. 2752.

mientos más dinámicos: cinco se entrelazan en una danza en fila y las otras cuatro, también danzando, tocan un tambor y címbalos medianos, que dan idea del estrépito que ocasionarían, frente a las campanitas de las imágenes anteriormente comentadas.

Otra danza en fila con ocho mujeres y con una disposición similar a esta se encuentra en otro Salterio de ca. 1400, esta vez serbio, conservado en la Staatsbibliothek de Múnich, ms. eslavo 4, fol. 186v. ${ }^{\circ}$. Acompañan a Míriam, que también danza con unas çarparas en su mano derecha y un pañuelo en la izquierda. Es decir, que ciertas formas de disponer las danzas van pasando de un manuscrito a otro por el procedimiento de la copia, algo muy frecuente en estos siglos ${ }^{80}$. No obstante, también tenemos imágenes novedosas en este mismo manuscrito, en su folio $184 \mathrm{v}^{\circ}{ }^{\circ}$, como es la danza en rueda de nueve hombres que lo hacen al son de un tamboril. En un registro superior se encuentra el rey David rodeado de instrumentistas, entre ellos dos laudistas con laúdes de caja abombada mostrados de perfil acompañando el texto del Salmo $150^{81}$.

80 Ibidem.

81 Cfr. T. Seebass, Musikdarstellung und Psalterillustration im früheren mittelalter, vol. II, p. 92. 


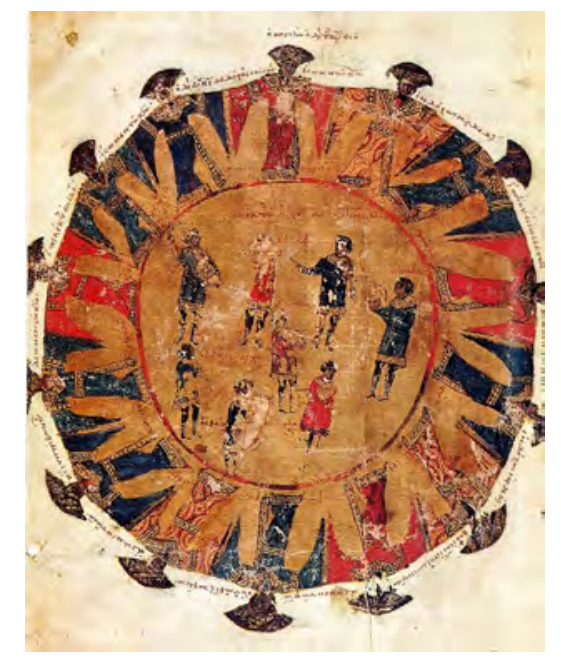

Lám. 25. Fol. 449v. ${ }^{\circ}$ del Salterio Vat. gr. 752, del año 1059.

Pero también existen disposiciones diferentes y menos estructuradas, como las del llamado Salterio de Kiev de 1397 (Biblioteca M.E. Saltykov-Shchedrin Public Library, ms. F VI), donde en sus fols. 206r. ${ }^{\circ}$ y $207 \mathrm{v}^{\circ}$ dispone a varios músicos tañendo tambores de doble parche con percutor en forma de L invertida, trompeta recta y címbalos, acompañando en un caso a Míriam y en otro a un personaje masculino. En ambas imágenes se trata de danzas individuales. Aunque el tema de la danza de Míriam es recurrente en este pasaje bíblico, también hemos encontrado un Salterio donde la interpretación de la alegría de los israelitas ante este acontecimiento del paso del mar Rojo no se realiza por medio de la danza, sino por medio de música instrumental ruidosa, conformada por dos gruesas trompetas (hatzotzeroth en hebreo), un cuerno (shofar) y címbalos (zelzlim) en manos de Míriam. Esto es lo que nos muestra un manuscrito eslavo del Salterio, fechado entre los siglos XIII-XIV, que se conserva en el Museo Histórico de Moscú, ms. 3, fol. 270v. ${ }^{\circ}$. Aquí no se ha utilizado la técnica característica de las miniaturas, sino dibujos a plumilla nerviosos y escuetos ${ }^{82}$. Como se ve, las propuestas son variadas.

Ahora bien, no podemos cerrar este epígrafe sin ocuparnos de una miniatura espectacular contenida en el famoso Salterio de la Biblioteca Vaticana, gr. 752, fol. $449 \mathrm{v}^{\circ}{ }^{\circ}$ del año 1059 (lám. 25), correspondiente a este pasaje bíblico.

Está situada entre el final del Salterio y el comienzo de las Odas. Es una miniatura a página completa en forma de circunferencia, con un círculo interno que muestra a ocho músicos, a los que volveremos más adelante, y otro externo donde se 
despliegan catorce mujeres danzando revestidas con ropajes de ricas telas en tonos azules, rojos y estampados en blanco y rojo, adornados con cenefas doradas tanto en los bordes de las faldas y grandes cuellos como en las largas mangas y en los cintos con lazadas que llegan al suelo. Asimismo, llevan un raro tocado de tronco de cono abierto, que junto con las mangas que se ensanchan de forma muy llamativa y acaban en punta nos recuerdan las vestimentas chinas de la dinastía Tang (618-907) y poco tienen que ver con las bizantinas de otras miniaturas coetáneas. Desde luego, los contactos de Bizancio con ámbitos alejados de la capital eran muy frecuentes, y se conoce perfectamente la ruta de la seda que venía de China desde antiguo, por lo que no tiene nada de extrańo que también llegaran ropajes fabricados con este tipo de tejido. No obstante, habría que considerar también las influencias que pudo haber recibido el miniaturista sobre indumentaria a través de otros códices.

Estas catorce mujeres, presididas por Míriam, llevan los brazos extendidos y van entrelazadas por los hombros, cruzando la pierna izquierda por delante de la derecha, como si se desplazaran lenta y conjuntamente realizando una especie de sirtaki ${ }^{83}$ medieval en su parte lenta, lo que se denominaba el «argos» o «baris». Por encima de sus hombros se despliega una inscripción con una selección del texto de la Oda de Moisés, que se lee de derecha a izquierda, la misma dirección que parecen tomar las bailarinas. La miniatura ha merecido un artículo monográfico por parte de la investigadora búlgara Svetlana Kujumzieva ${ }^{84}$, quien, también sorprendida por la singularidad de esta pintura, ha realizado un estudio iconográfico sobre ella, llegando a la conclusión, entre otras, de que su confección coincidió con la coronación del nuevo emperador Constantino Dukas X, el 24 de noviembre de 1059, y que el círculo representa su corona. Sea cual sea el auténtico sentido de esta miniatura, lo cierto es que es una imagen singular e ingeniosa, al hacer confluir en un doble círculo las dos propuestas iconográficas que encierran los Salterios: la del conjunto de músicos del rey David referentes al salmo 150 en el círculo central y la danza de Míriam y las hijas de Israel concerniente a la primera Oda en el periférico. Esta miniatura, sin duda, hace de este códice, que ya de por sí es uno de los más ricos que existen por la utilización de sus fondos de oro y por su número de imágenes y propuestas, uno de los más interesantes para el estudio de diversas temáticas, entre ellas la musical y la de la indumentaria ${ }^{85}$.

${ }^{83}$ El sirtaki fue inventado por Giorgos Provias para la película Zorba el griego en 1964, pero basa sus movimientos y pasos en el Hasapiko, una danza tradicional militar que fue copiada por el gremio de carniceros. La danza fue muy popular en Constantinopla y Asia Menor durante la Edad Media.

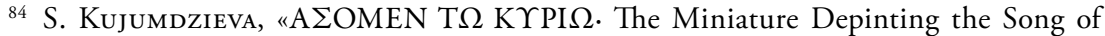
Moses in Manuscript Vat-gr. 752». Music in Art, Research Center for Music Iconography, New York, vol. XXVI/1-2 (2001), pp. 93-106.

${ }^{85}$ No sabemos si por causa del oro o por otras causas esta miniatura ha sufrido grandes pérdidas de pintura, de ahí que utilicemos para nuestro trabajo la imagen que reprodujo Tilman SEEBASS en su libro Musikdarstellung und Psalterillustration im früheren Mittelalter. Studien ausgehend von einer Ikonologie der handschrift París Bibliothèque Nationale fonds latin 1118, vol. II, Bern, Francke Verlag, 1973, p. 2. Es verdad que los tonos son rojizos y se diferencian bastante del original, que 

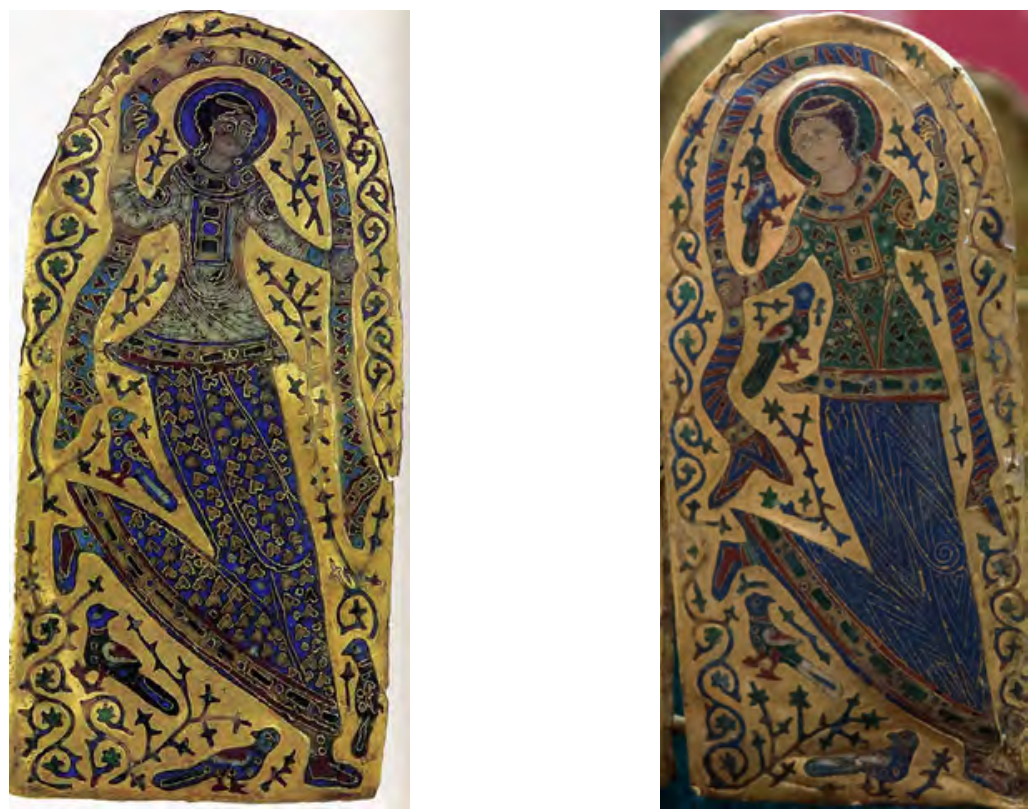

Lám. 26. Placa con danzarina de la corona de oro y esmalte cloisonné del emperador Constantino IX Monomachos, siglo XI.

Por último, tan solo nos queda mencionar las dos hermosas bailarinas que aparecen en las placas de esmalte de la corona de Constantino IX Monomachos (1042-1050), conservadas en el Museo de Bellas Artes de Budapest (láms. 26 a y b).

En ellas está retratado junto a su esposa la emperatriz Zoe y la hermana de esta, Teodora, que también llegó a reinar. Junto a los personajes reales que ocupan las tres placas centrales aparecen otras dos con bailarinas, que llevan una pierna elevada hacia atrás en expresión del movimiento, y las manos también elevadas manipulando una larga cinta con la que hacen figuras en el aire y dan colorido a la danza. Las danzarinas van ataviadas con largas faldas y cuerpos de colores contrastantes llenos de abalorios. Representan los festejos que se realizaron en Constantinopla con motivo de la coronación de este nuevo basileus. Completan las siete placas personificaciones de la Verdad y la Humildad.

tiene tonos dorados más pálidos, pero al menos se pueden ver los instrumentos con más precisión, al haber sido tomada la fotografía a principios de los ańos setenta del siglo pasado, cuando la pintura aún no estaba tan deteriorada. Lo curioso es que se han conservado perfectamente todos los fondos dorados, pero se ha saltado la pintura de las figuras y los objetos, lo que ha propiciado la observación de los dibujos previos, mostrándose de esta manera el procedimiento de trabajo de los miniaturistas. 


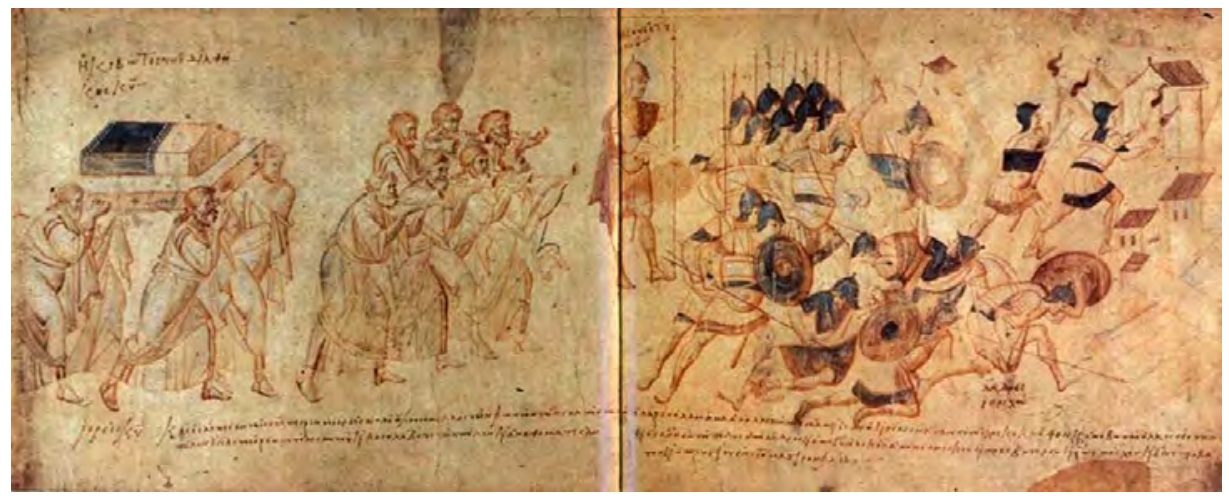

Lám. 27. Rollo de Josué. Papiro bizantino de ca. 900.

Bibl. Vaticana. Ms.pal. gr. 431, Seq. v. (C).

\subsubsection{La toma de Jericó (Josué 6, 1-21)}

Aunque desde el punto de vista musical este tema no tenga tanta trascendencia, sí que la tiene desde el iconográfico, pues está tratado en el famoso Rollo de Josué, papiro bizantino fechado en torno al 900, que se conserva en la Biblioteca Vaticana (Ms. Pal. Gr. 431, Seq. V; lám. 27). En esta miniatura se describe la toma de la ciudad según el Libro que lleva el nombre del personaje, en la que los israelitas conducen el Arca de la Alianza en torno a Jericó, precedidos por siete levitas que tocan el shofar, cuernos de cabra o de carnero típicos de esta cultura, utilizados tanto en el Templo de Jerusalén como en las sinagogas como instrumento de señales.

Los levitas lo tocaban en las ceremonias de la Luna Nueva, el día de Año Nuevo, el día de la Expiación, en los Años de Jubileo y en los días de ayuno, además de en otra serie de circunstancias. Sus toques estaban perfectamente reglamentados, según el Talmud, pudiendo emitir dos sonidos: la nota fundamental y la quinta. En este pasaje bíblico son las potentes vibraciones de estos cuernos sonando al unísono con su ruido ensordecedor lo que ocasiona la caída de los muros de la ciudad. Esta miniatura, con cuernos muy simples, es el ejemplo más antiguo que encontramos en el arte bizantino con esta temática, a la que le siguen varias más contenidas en los Octateucos. De todas ellas tan solo vamos a citar la del códice griego del siglo XII de la Biblioteca Vaticana 746, pt. 2, fol. 446r. ${ }^{\circ}$ (lám. 28), en la que nueve shofarin tañen ahora junto al Arca de la Alianza, cuatro la preceden y cinco la siguen, mientras uno descansa sobre un pequeño muro en el primer plano de la imagen. Los aerófonos van ornamentados con líneas paralelas de trecho en trecho. Son ya instrumentos más elaborados que los del famoso Rollo de Josué. 


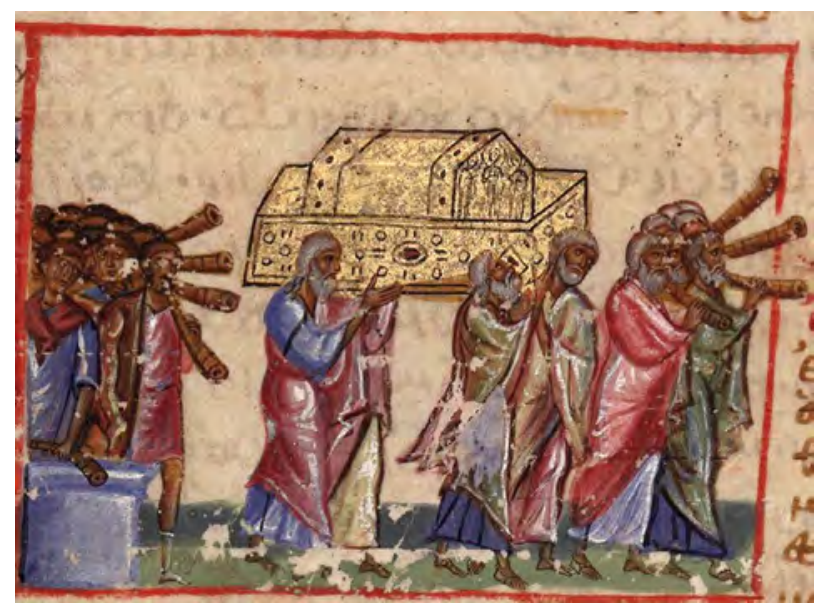

Lám. 28. Octateuco de la Biblioteca Vaticana 746, pt. 2, fol. 446r. ${ }^{\circ}$. (․

\subsubsection{El rey David}

El de este monarca bíblico fue un tema recurrente a lo largo de toda la Edad Media, debido a su vinculación con Cristo, ya que no solo lo prefigura, sino que al mismo tiempo es su antecesor. Como se sabe, en la genealogía de Jesé, contenida al comienzo del Evangelio de Mateo, Cristo y la Virgen aparecen como descendientes suyos.

Si este aspecto de David es el que más le interesaba a los teólogos, no cabe duda de que la faceta musical es la que tuvo una mayor trascendencia en la iconografía de todo el Medievo. Si a esto ańadimos su papel como poeta, autor supuesto de los Salmos, y su importancia como organizador de la liturgia, según lo explicita el Libro I de las Crónicas (15 y 16), comprenderemos el éxito de este tema tanto en el Imperio bizantino como en el Occidente europeo. En Oriente las iluminaciones de los Salmos se cuentan entre las escasas obras que incluyen instrumentos musicales, debido a que el tema lo requería, lo mismo que va a suceder en Occidente durante el período altomedieval.

Ya vimos un par de escenas de la vida de David en el período anterior, labradas en plata en sendas bandejas del reinado del basileus Heraclio (610-641) ${ }^{86}$. Se trataba de David pastor en su juventud antes de ser consagrado por Samuel, una escena que se va a repetir en muchos Salterios, además de aquella de su boda con Mical, bendecida por el rey Saúl.

${ }^{86}$ Fue el primer emperador bizantino que adoptó el nombre de basileus, que a partir de 
Ahora, en esta etapa, se contemplan otras facetas de su rica biografía, en la que la música hará acto de presencia en forma de instrumento musical, quedando algunas de estas facetas fijadas tanto en la iconografía bizantina como en la occidental durante varios siglos. Serán especialmente la mencionada de David como pastor y la de David entronizado, bien solo o bien rodeado de sus cuatro músicos, Asaph, Eman, Ethan e Idithum (a veces la iconografía suprime a dos), cuyos nombres figuran escritos en la propia miniatura.

El primer códice que nos lo muestra será el famoso Khludov (Museo Histórico de Moscú, col. Millet, B.1530, $1 .{ }^{a}$ mitad del siglo Ix) en su frontispicio (fol. $2 \mathrm{v}^{\circ}{ }^{\circ}$ ) y en sus folios $24 r^{\circ}$ y $147 \mathrm{v}^{\circ}$. En estos dos últimos, lo encontramos en su oficio de juventud cuidando del rebańo, pero ya en ellos se nos muestra con una gran dignidad, de pie en el primero o sentado sobre una roca tańendo un cordófono inventado y simbólico en el segundo: el llamado salterio cuadrado, al que se le atribuían diez cuerdas como símbolo de los Diez Mandamientos, aunque a veces en las imágenes su número fuera menor (fol. 147v. ${ }^{\circ}$ ); y también con un modelo rectangular (fol. 24r..$^{\circ}$ ), simplificación de las antiguas cítaras de caja que hemos visto en el período anterior.

Evidentemente, cuando uno contempla este instrumento (lám. 29), percibe que su dibujo no corresponde a un instrumento real, porque aquí el miniaturista, posiblemente bajo algún influjo occidental ${ }^{87}$, ha tratado de adaptar la imagen a lo que dos textos de la época señalaban: la llamada Carta a Dardano, atribuida erróneamente a san Jerónimo ${ }^{88}$ y el De universo (Lib. XVIII, 4) de Hrabanus Maurus, redactado entre el 842 y el 847 en Fulda, en quien confluyen varias tradiciones como fiel discípulo que fue de Alcuino de York. El primero es un tratado titulado De diversis generibus musicorum, que incorpora fragmentos de comentarios antiguos de salmos y las Etimologías de san Isidoro. Su popularidad en la Edad Media fue tal que se copia en más de 75 manuscritos fechados entre los siglos IX y Xv. Parte de él lo recoge el propio Maurus en el capítulo De musica et partibus eius de su enciclopedia, además de formar parte de colecciones de manuscritos de teoría musical, como una de las introducciones al libro de los Salmos ${ }^{89}$. En ambos textos se vuelve a hablar del psalterium triangular en forma de $\Delta$, al que se le adjudican 24 cuerdas, que simbolizan las voces de los 24 Ancianos, según apunta Maurus ${ }^{90}$, y se introduce un nuevo tipo: el psalterium quadratum, en forma de escudo y con diez cuerdas, haciendo alusión al texto salmódico, según señala este autor ${ }^{91}$. Y refiriéndose al

${ }^{87}$ Los contactos entre monjes de Oriente y Occidente debieron ser frecuentes, aparte de aquellos oficiales entre los monarcas carolingios y los basileus. Ejemplos gráficos del psalterium cuadrado hay muchos en Europa, como se puede comprobar en las imágenes que ofrece T. SEebass en Musikdarstellung und Psalterillustration..., vol. II.

${ }^{88}$ Migne, Patrología Latina, xxx, col. 213.

89 T. Seebass, «Idee und Status der Harfe im Europäische Mittelalter». Basler Jahrbuch für Historische Musikpraxis, vol. XI (1987), pp. 139-152, pp. 141-142.

${ }^{90}$ Ibidem.

${ }_{91}$ «Psalterium, quod Hebraice nablum, Graece autem Psalterium, Latine autem Laudatorium dicitur, de quo in quinquagesimo quarto psalmo dicit: 'Exsurge, psalterium et cithara'; non quod in modum citharae, sed quod in modum clypei quadrati conformetur, cum chordis decem, sicut scriptum est: 


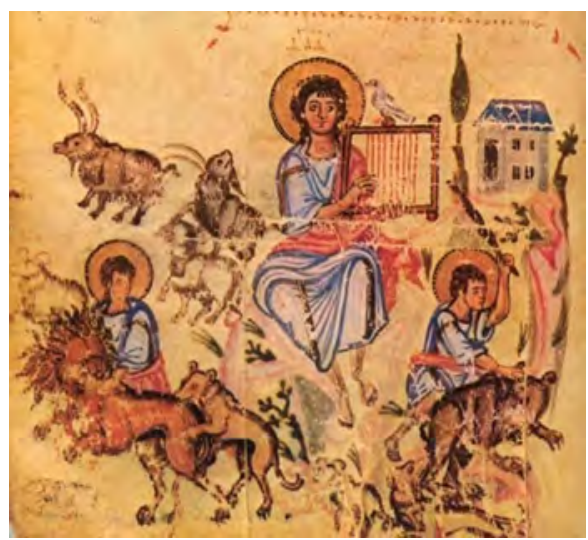

Lám. 29. Salterio Khludov, $1 .^{\mathrm{a}}$ mitad del siglo IX, fol. $147 \mathrm{v}^{\circ}$. Museo Histórico de Moscú, col. Millet, B.1530.

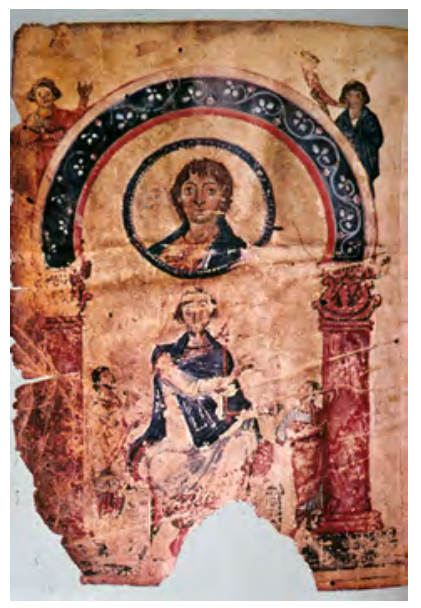

Lám. 30. Salterio Khludov, $1 .^{\mathrm{a}}$ mitad del siglo Ix, fol. 2v. ${ }^{\circ}$. Museo Histórico de Moscú, col. Millet, B.1530.

psalterium decachordum, de forma cuadrada, Maurus explica que las diez cuerdas simbolizan los Diez Mandamientos y los cuatro lados, los Evangelios.

Pues bien, estos textos hacen pensar a los miniaturistas y a sus mentores que se refieren a instrumentos reales cuando no lo son, sino que responden a descripciones simbólicas a las que habían llegado los escritores sagrados para justificar la presencia de instrumentos musicales en los textos de los Salmos, puesto que durante los primeros siglos del cristianismo los Padres de la Iglesia, tanto los de la griega como los de la latina se opusieron al uso de los mismos, como ya hemos venido repitiendo, no solo en las iglesias sino también en la vida cotidiana de los cristianos, sintiéndose obligados a elaborar largas explicaciones (Enarrationes in Psalmum..., seguido del número del mismo) para, como he dicho, justificarlos ${ }^{92}$. Esta forma cuadrada no vuelve a aparecer en las páginas del Khludov, pero sí la rectangular, cuyos primeros ejemplos los tenemos aquí, en el folio $24 \mathrm{r}^{\circ}$ ya citado y en el frontispicio (fol. $2 \mathrm{v}^{\circ}$ ), que inaugura, al menos así lo creemos al no tener otros ejemplos anteriores, las imágenes de David entronizado tañendo un cordófono y rodeado por sus músicos (lám. 30), levitas escogidos por él para esta función.

In psalterio decem chordarum psallam tibi». Hrabanus Maurus, De Universo, XVIII, 4, ed. Migne, PL, CXI, col. 498. Cfr. T. SeEbass, Musikdarstellung und Psalterillustration im früheren Mittelalter. Studien ausgehend von einer Ikonologie der handschrift París Bibliothèque Nationale fonds latin 1118. Berna, Francke Verlag, 1973, p. 130.

92 Toda esta problemática de los instrumentos simbólicos viene explicada y resumida en R. Álvarez, «El arpa-cítara (rota): su probable origen bizantino y su trayectoria mediterránea hacia la Europa occidental». Revista de Musicología, vol. xxiI, núm. 1 (1999), pp. 13-19. 
Aquí David porta una cítara rectangular, configurada por un sencillo marco sin caja de resonancia ni otros elementos constitutivos, pero sí con cuerdas que son pulsadas por el monarca ${ }^{93}$. Junto a él dos músicos tañen unas campanas y un laúd corto con mango como prolongación de la caja, llamado en esta zona lyra bizantina, que constituye la primera imagen que tenemos de ella en Bizancio, antes de expandirse por la Europa occidental en los siglos X-XI. Como se sabe, este cordófono aún se conserva en las músicas de tradición oral de Grecia y de otras zonas de la Europa oriental, y es muy popular ${ }^{94}$.

El trono de David en esta miniatura está situado bajo un arco de medio punto sostenido por gruesas columnas con capiteles corintios y sobre este y en sus extremos vemos a los dos músicos restantes tocando un tamborcillo en forma de clepsidra y un gran cuerno. Este modelo de tambor con doble parche que se toca horizontalmente, golpeando con cada mano una membrana, es muy curioso y vuelve a aparecer en el folio $37 \mathrm{v} .{ }^{\circ}$ del propio Khludov y también en el folio $2 \mathrm{r}^{\circ}$ del códice 61 (ahora Petrop. gr. 265) del monasterio de Pantokratoros en el monte Athos, de la misma centuria (lám. 31).

Y digo que es curioso porque tan solo hemos encontrado esta tipología de tambor popular en la Península Ibérica en la centuria siguiente, en el Beato de Valcavado del 970 (fol. 199v. ${ }^{\circ}$ ) y en aquellos otros códices beatianos que en cierta manera están relacionados con este (Beatos de la Seo de Urgel, de Fernando I y de Silos), aunque aquí la postura de percusión sea la vertical. Esto confirmaría las influencias orientales de las que hemos hablado en las miniaturas de los Beatos ${ }^{95}$. Esta caja del tambor del Pantokratoros es muy llamativa, al ir decorada con franjas rojas y amarillas.

Y volviendo a los cordófonos, hay que señalar que la forma cuadrada de psalterium que hemos visto en este manuscrito no va a ser muy común a partir de entonces, pues tan solo la volvemos a encontrar en algunas miniaturas del David pastor en los códices de dos Salterios del siglo xi: el Barberini gr. 372 de la Biblioteca Vaticana del año 1050 (fol. 44v. ${ }^{\circ}$ ) y el Theodore de la British Library Add. 19352 del ańo 1066 (fol. 28r. ${ }^{\circ}$ ). En cambio, sí que persistirá la rectangular como esquematización de la cítara de caja romana que hemos visto en varios ejemplos de

${ }_{93}$ Un instrumento similar se puede ver en un Salterio inglés (British Library, C VI, fol. $\left.16 v^{\circ}\right)$ elaborado en Winchester, que también contiene la carta a Dardano.

${ }^{94}$ Hay que seńalar en este punto que resulta curioso que tanto Bizancio como el Occidente europeo conserven la terminología antigua para determinadas tipologías instrumentales nuevas, en griego el primero ( $\pi \alpha v \delta \circ v p \alpha, \sigma \alpha \lambda \pi \iota v \xi$, $\kappa \iota \theta \alpha p \alpha, \lambda \iota p \alpha$, etc.), y en latín el segundo (lira, cítara, pandura), aplicando esos antiguos nombres a los nuevos instrumentos que van recibiendo de otras culturas, al menos en los textos escritos de la plena Edad Media. Será después cuando se vayan implantando en las lenguas romances los nuevos nombres para las nuevas formas.

95 R. Álvarez, «La iconografía musical de los Beatos de los siglos X y XI y su procedencia». Anuario del Departamento de Historia y Teoría del Arte, vol. v, Universidad Autónoma de Madrid, 1993, pp. 201-218; y «Vestigios iconográficos de la liturgia y de la música del rito viejo-hispánico en los códices de Beato de Liébana», en R. Álvarez, I. Fernández y A. Llorens (eds.), El canto mozárabe y su entorno. Estudios sobre la música de la liturgia viejo hispánica, Madrid, SEdeM, 2013, pp. 293-336. 


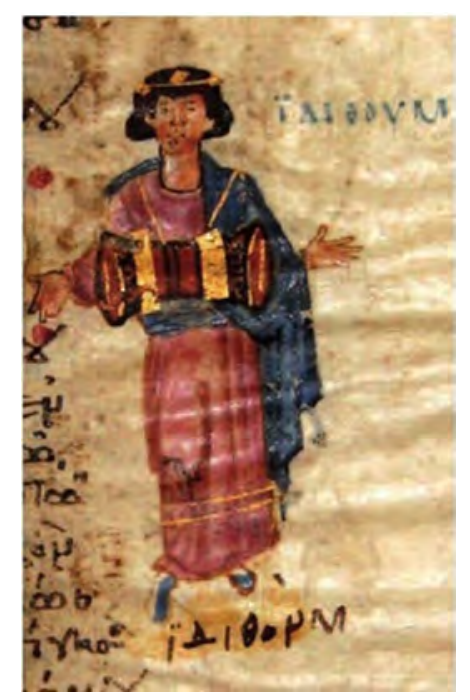

Lám. 31. Salterio del monasterio Pantokratoros, códice 61, fol. 2r. ${ }^{\circ}$. Monte Athos.

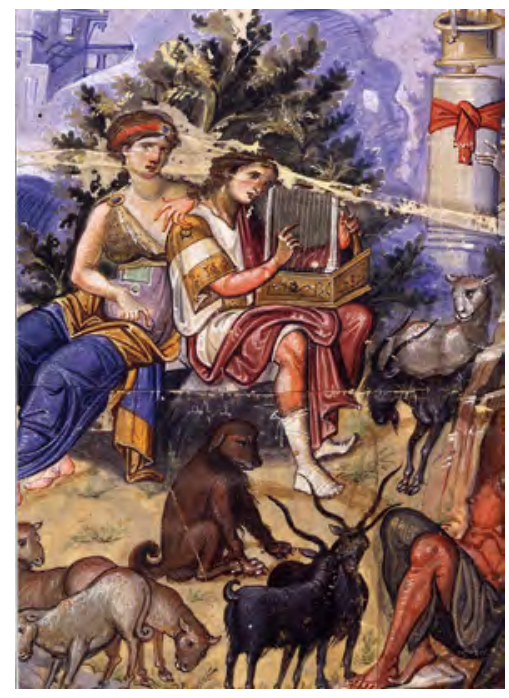

Lám. 32. Salterio de la Biblioteca Nacional de París, ms.139, fol. 1 v. ${ }^{\circ}$. David como pastor.

la primera Edad de Oro, que se ha quedado reducida a un rectángulo, es decir, al marco de las cuerdas soportadas por una estrecha caja como base a la que a veces se le ha ańadido una pieza curva a la derecha por donde se agarra el instrumento, que ha confundido a más de un investigador ${ }^{96}$. La mejor imagen de este tipo, que constituyó un modelo para códices posteriores, se encuentra en uno de los Salterios «aristocráticos» de la Biblioteca Nacional de París (lám. 32), el famoso códice griego 139 (fol. 1v. ${ }^{\circ}$ ), realizado con todo lujo en el taller imperial de Constantinopla a principios del siglo x y copiado de un original del siglo vi, según se cree ${ }^{97}$, en el que sobreviven un número de elementos clásicos, como los de la figura alegórica de la Melodía, que, sentada a espaldas de David, parece inspirarlo o la personificación del Monte o la de la Noche al fondo, que se han incluido para representar los fenómenos de la naturaleza.

${ }^{96}$ F. De' MaffeI, op. cit., p. 77, cree que esto es un instrumento fidedigno e intenta imaginarse cómo sería, pero no es otra cosa que la visión que nos ofrece un miniaturista o eborario de la cítara romana, que nunca ha visto porque en su época ya ha desaparecido, y que dibuja copiando un bajorrelieve romano de varios siglos antes, como el que mostramos en la lám. 9. Como lo que ve es el brazo de la cítara que queda en primer plano, porque el otro queda oculto, es solo este el que dibuja, lo que da lugar a un instrumento anacrónico.

\footnotetext{
${ }^{7}$ Ibidem.
} 


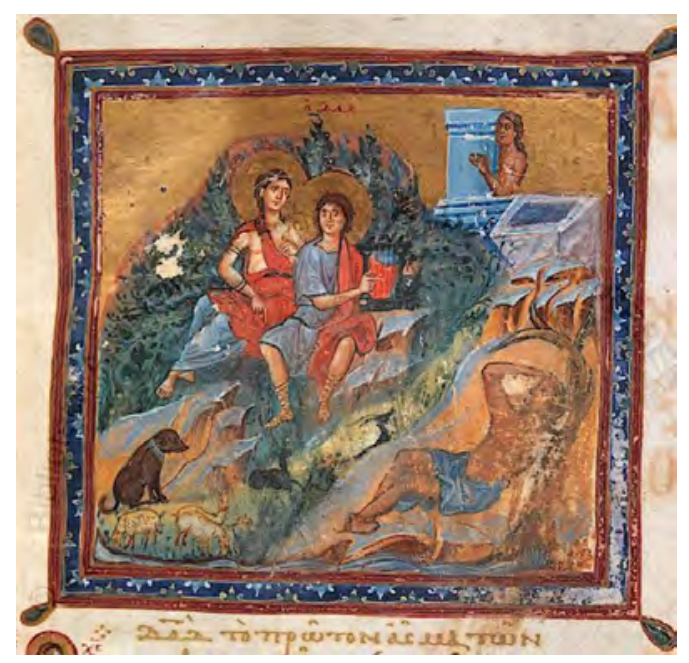

Lám. 33. Salterio del siglo xıII. Biblioteca Vaticana, Barberini, gr. 320, fol. 2r.‥ ().

David aparece aquí sentado en una roca y rodeado de animales ${ }^{98}$, tañendo el cordófono, que, como ya he dicho, es una simplificación de lo que fue una cítara de caja tardorromana, cuyo modelo más perfecto se ha mostrado en el marfil del siglo $\mathrm{V}$ de la Biblioteca del Arsenal de París (lám. 9). Aunque la miniatura está deteriorada justamente a la altura del yugo y de los discos terminales de este, no obstante, estos se perciben. Y si esta imagen es indudablemente una mala copia, en cuanto al instrumento se refiere, de otra de la Antigüedad tardía, que no se entiende porque el instrumento ya no existe y los miniaturistas nunca lo han visto, pasados otros dos o tres siglos, al copiarse de nuevo, el resultado es aún peor, como queda a la vista en la miniatura del códice Barberini griego 320 de la Biblioteca Vaticana (lám. 33), fechado en el siglo XIII (fol. 2r. ${ }^{\circ}$ ). Y es más: en el propio siglo XI y dentro de los salterios aristocráticos se vuelve a copiar con los anacronismos que estamos viendo en otros códices, tal y como lo muestra el ejemplar de la British Library, Add 3692899.

98 Se le han dado muchas interpretaciones a esta miniatura. La más extendida es la que cree ver en David músico rodeado de animales la figura de Orfeo, idea que recoge E.R. PAnYagua, «El influjo de la figura de Orfeo en la iconografía de David músico». Helmántica, vol. 45 (1994), pp. 331-338, donde explica, entre otras cosas, que detrás de David se encuentra la imagen alegórica de la Melodía, lo que confirma la inscripción en griego a la izquierda del personaje, que el hombre desnudo y entre rocas del primer plano representa la Montaña de Belén, y que la figura que aparece por detrás de una columna sacra es una ninfa, todo lo cual tiene recuerdos del arte helenístico, según él. Discrepamos, no obstante, sobre esto último, porque la cítara de esta miniatura no es helenística sino tardorromana.

${ }^{99}$ https://www.bl.uk/collection-items/11th-century-aristocratic-psalter. 


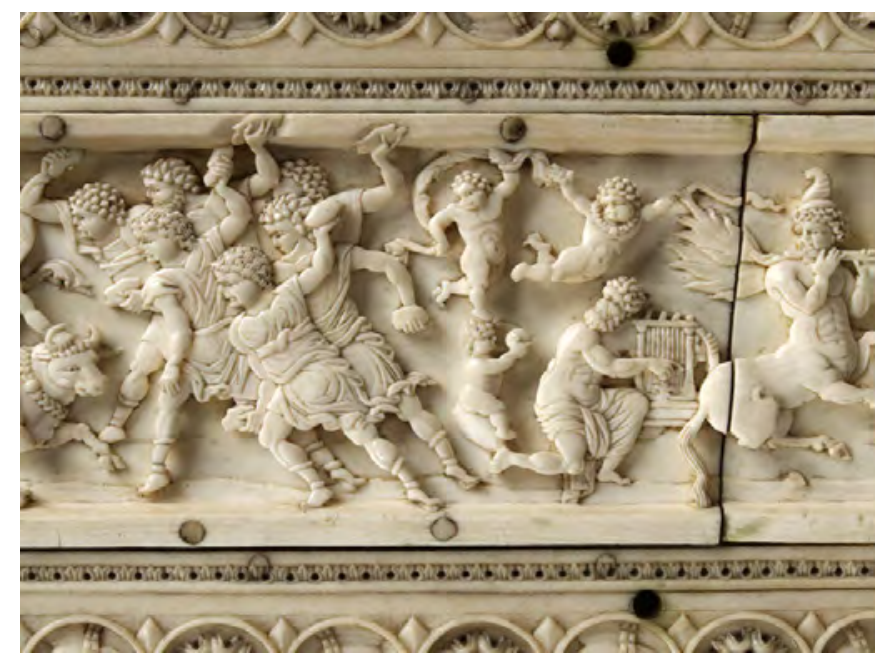

Lám. 34. Cofre Veroli, 2. ${ }^{a}$ mitad del siglo x. Museo Victoria y Alberto de Londres.

Pero este instrumento fosilizado no solo se ve en la miniatura, sino que de ella también pasó a la eboraria, como se puede comprobar en los cofres de rosetas del período macedonio (siglos $\mathrm{x}$-XI), y aquí con más razón por el tipo de técnica utilizada, que dado el pequeño tamaño de las piezas había que simplificar al máximo los objetos. Las figuritas de músicos de estos cofres, muchas de ellas descontextualizadas dentro de recuadros, son interesantes porque tañen tambores cilíndricos con amarres en zigzag, flautas traveseras y siringas, y por supuesto el tipo de cítara que estamos mencionando, auténticos esquemas de cítaras rectangulares, con ese confuso brazo que evidencia la dependencia de la miniatura del ms. 139 de París. Así, por ejemplo, lo vemos en el cofre que, procedente de la catedral de Veroli, se encuentra en el Museo Victoria y Alberto de Londres (2. ${ }^{a}$ mitad del siglo X), en la escena mitológica del rapto de Europa junto a un centauro que sopla una flauta travesera (lám. 34), pero hay otros instrumentos iguales.

Ahora bien, en el siglo IX aparece otra imagen de la cítara totalmente rectangular sin el añadido del brazo. Este modelo se encuentra en la famosa miniatura del códice de la Cosmografía de Komas Indikopleustes de la Biblioteca Vaticana, ms. 699, fol. 63v. ${ }^{\circ}$, un modelo que va a tener muchas réplicas tanto en la miniatura como en objetos de marfil, pues en el cofre del Palacio de Venecia de Roma, que muestra diferentes escenas de la vida de David, vemos a este junto al lecho de Saúl calmándole su melancolía con la música, mientras tañe una voluminosa cítara, realizada de forma muy burda por el eborario, donde se ven seis cuerdas flanqueadas por dos pequeńas columnas con capiteles. En la parte superior y situados sobre una banda aparecen dos filas de botones, que supuestamente indican la colocación de las collopès, una interpretación muy personal del eborario, que nunca había visto una cítara grecorromana. 


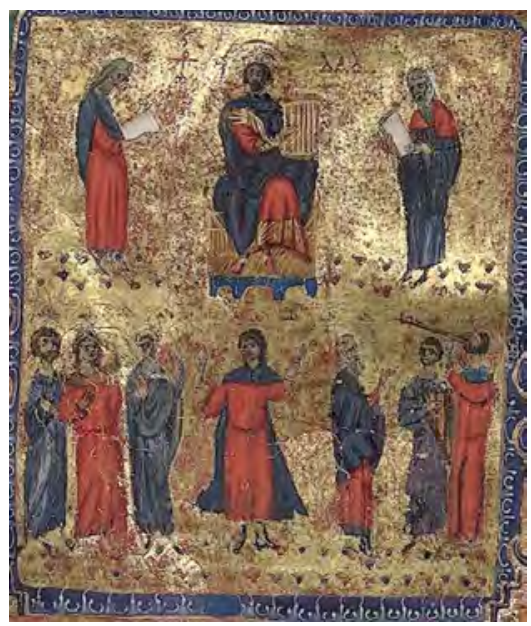

Lám. 35. Salterio de 1050. Biblioteca Vaticana, Barberini, gr. 372, fol. 5r. ${ }^{\circ}$ (C)

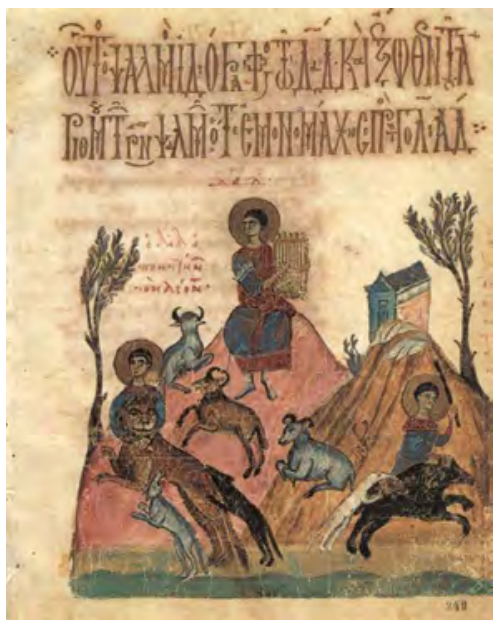

Lám. 36. Salterio de 1050. Biblioteca Vaticana, Barberini, gr. 372, fol. 248r. ${ }^{\circ}$. ().

Otras imágenes de esta tipología rectangular las encontramos en códices de mediados del siglo XI, como el Barberini gr. 372 de la Biblioteca Vaticana del año 1050, fols. 5r. ${ }^{\circ}$ (lám. 35) y 248r. ${ }^{\circ}$ (lám. 36); el Vaticano gr. 752 (año 1059), en los fols. $1 \mathrm{v} .^{\circ}$ y $448 r^{\circ}$, donde aparece David con la Melodía en una nueva copia, esta vez más sencilla, del fol. 1v. ${ }^{\circ}$ del Salterio 139 de la B.N. de París; y en el folio $188 \mathrm{v} .^{\circ}$ del Salterio Theodore (año 1066) de la British Library de Londres, ms. Add. 19352, manuscrito finalizado en 1066 en el scriptorium de San Juan de Studios, en Constantinopla, por un monje que procedía del monasterio de San Basilio de Caesarea, y que desde nuestro punto de vista debió tener contactos con el miniaturista del códice Taphou 14, hoy en la Biblioteca del Patriarca en Jerusalén, pues hay figurillas similares en ambos códices.

Ahora bien, dejando de lado estas cítaras irreales, tenemos que ver todos aquellos instrumentos auténticamente reales que nos muestran algunos folios de estos salterios, tanto del siglo XI y el XII como algunos más tardíos. Esto nos dará la medida del instrumentario que se usaba en ese largo período en que gobernaron las dinastías de Comnenos y Paleólogos. Del siglo Xı hay tres Salterios muy interesantes que ya hemos mencionado, como son el Barberini gr. 372, el Theodore de la British Library y sobre todo el Vaticano 752 . El primero nos muestra en el fol. $5 \mathrm{v}^{\circ}{ }^{\circ}$, debajo de la figura de David entronizado, a un grupo de músicos que rodean a Míriam, que danza con los brazos elevados y posiblemente con campanitas en las manos. Se explicita así que este códice también contiene las Odas y no solo los Salmos.

A su derecha hay un personaje que parece dirigir la música interpretada por un arpa-cítara y por un aerófono de tubo largo y ligeramente cónico, que podría ser una trompeta, al estar dirigido hacia arriba. A la izquierda se han dispuesto otros 


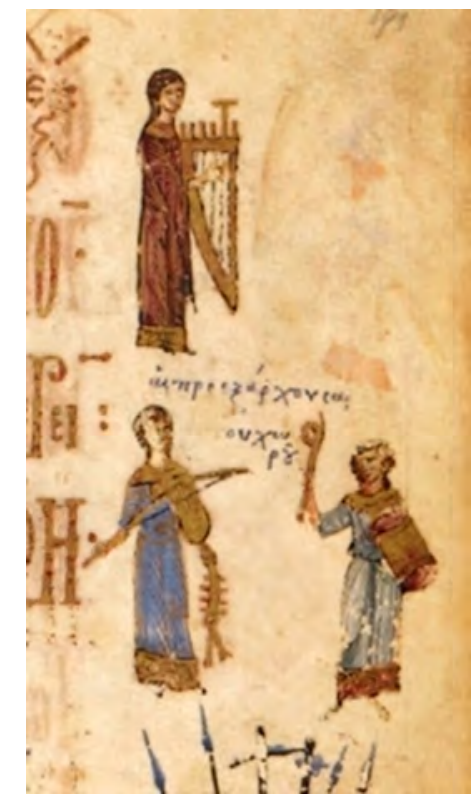

Lám. 37. Salterio Theodore de 1066, fol. 191r. ${ }^{\circ}$. Biblioteca

Británica de Londres, ms. Add. 19352. (C).

tres personajes, de los cuales el central es una mujer, que parece tocar un pequeño tambor de marco para acompañar la danza. La pintura, a pesar de la riqueza que aportan los dorados, es pobre en cuanto a precisión de detalles y a dibujos de rostros y objetos, que están trazados de forma muy simple, por lo que resulta difícil identificar estos últimos, aparte de que hay falta de pintura. No obstante, resulta interesante ver aparecer aquí por primera vez el arpa-cítara que tanta trascendencia va a adquirir tanto en el imperio como más tarde en Europa.

Este cordófono vuelve a ser reproducido en el folio $191 \mathrm{r}^{\circ}$ del ya citado Salterio Theodore en una miniatura marginal, tañido en este caso por una de las hijas de Israel, quienes celebran la derrota del gigante Goliath a manos de David (lám. 37). Aquí se muestra también la llave de afinar y, lo que es más importante, la manera de colocar el instrumento, con la zona de las cuerdas más agudas pegadas al pecho de la instrumentista. Este cordófono de cuerdas punteadas se combina con un cordófono de mango de cuerdas frotadas por un extenso arco con mango, es decir, con lo que en la Península Ibérica se llamará dos siglos más tarde vihuela de arco, de caja entallada como la de la guitarra, mango independiente no muy largo y un clavijero en canal de la misma longitud que el mango con clavijas laterales, clavijero que en Europa será plano. Al final de este se ven los cabos de las tres o cuatro cuerdas que tiene. Y la postura en que se toca el instrumento, apoyada en el pecho bajo el cuello, será la que se tome en Europa más tarde para los cordófonos 


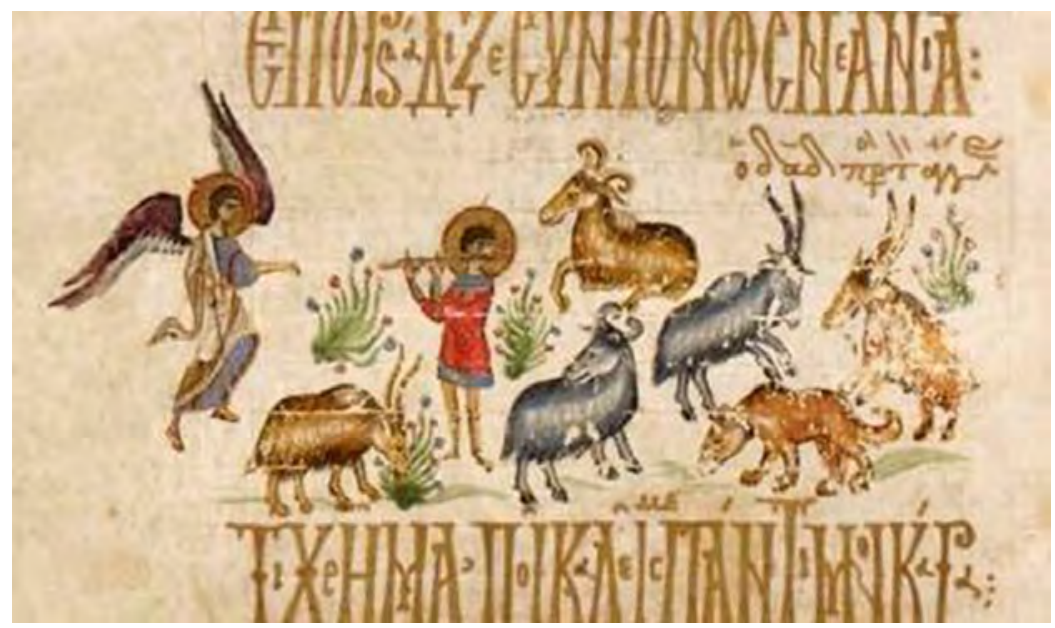

Lám. 38. Salterio Theodore de 1066, fol. 189v. ․ David como pastor.

de arco, que es la que ha permanecido hasta la actualidad ${ }^{100}$, por ejemplo en la viola. Completa el conjunto un tambor cilíndrico bastante profundo, que es golpeado con una baqueta de final enrollado ${ }^{101}$. Aparte de este grupo de instrumentistas, este Salterio nos ofrece también la imagen de un David niño entre su ganado (lám. 38) soplando una flauta travesera (fol. $189 \mathrm{v}^{\circ}$ ), imagen que puede homologarse a la de dos pastores del folio 33 del códice Taphou 14, asimismo del siglo XI, conservado en la Biblioteca Patriarcal de Jerusalén. En esta escena bucólica otro pastor, sentado a su vez en un altozano enfrente del anterior, sopla los variados tubos de una siringa (lám. 39). Ambas imágenes nos dan idea de los aerófonos que se utilizaban en el mundo aparentemente idílico de estos zagales.

No quiero dejar de mencionar que estos dos códices con miniaturas marginales presentan en algunos de sus folios a unos personajes con largas trompas muy decoradas de diversa curvatura que llaman la atención. Se ve así una ligeramente

${ }^{100}$ Hay que señalar que en el ámbito islámico la postura era la contraria, con el instrumento agarrado por el mango verticalmente, y esto es lo que se comprueba en la Península Ibérica en las primeras muestras de cordófonos frotados. Solo luego, y por influencia bizantina, la postura va a cambiar. Existe un ejemplo ¿bizantino? de los siglos X-XI con esta postura islámica de la que dudamos de su origen precisamente por esto. Se trata del pequeño putto que frota con un largo y elegante arco un cordófono de solo dos cuerdas con caja oval, apoyando la caja sobre su pierna izquierda (Colección Carrand del Museo de Florencia, núm. 26). Y dudamos porque no hemos encontrado en todo el arte bizantino, después del rastreo que hemos hecho, un cordófono frotado tocado en esta postura.

101 Es curiosa la forma de las baquetas de tambor bizantinas, con esos finales curvos o como aquí en forma de argolla, para ofrecer una mayor superficie al golpe en la membrana. 


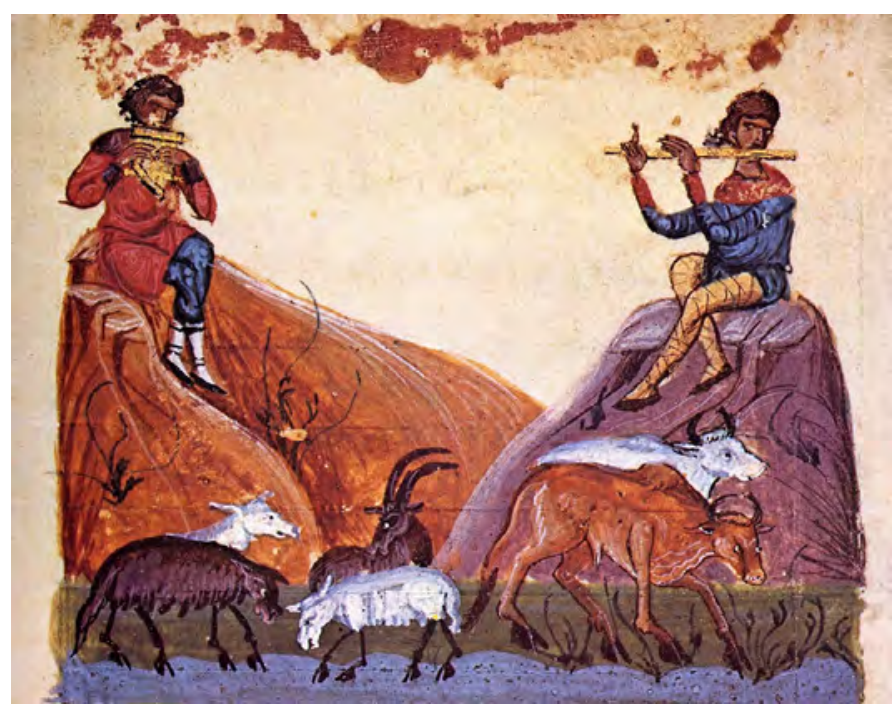

Lám. 39. Códice Taphou 14 del siglo xi. Biblioteca Patriarcal de Jerusalén, fol. 33.

curva, con franjas ornamentadas en el folio $109 \mathrm{r} .^{\circ}$ del Theodore, mientras que en el Barberini la curvatura del aerófono del folio $141 \mathrm{r} .^{\circ}$ es muy acusada, al doblarse el tubo hacia arriba a pocos centímetros de la embocadura. Su color negro apunta al ébano como su material de construcción, ornamentado con tres anillos dorados, aparte de un tramo cerca de su embocadura. Es un bello instrumento que llama la atención.

Si estos dos códices presentan una información valiosa sobre el instrumentario bizantino, la que ofrece el famoso Salterio 752 de la Biblioteca Vaticana es de un valor extraordinario. La realidad es que este códice, así como el Salterio Hamilton, son los dos manuscritos más importantes para nuestros fines por la cantidad y variedad de instrumentos musicales que presentan. En efecto, el 752, que está fechado en el año 1059, es decir, entre los dos códices anteriores, reúne en sus folios no menos de ocho con elementos musicales. Procede del monasterio de Pantanassa, en el Peloponeso, aunque no se sabe exactamente dónde se realizó, porque este monasterio es de fecha posterior al códice. Es un manuscrito rico, con fondos de oro, que ha quedado bien fijado, pero que ha contribuido a desprender la pintura de muchas figuras y objetos insertos en él. Ya citamos antes los folios $1 \mathrm{v} .{ }^{\circ}$ y $448 \mathrm{r} .^{\circ}$ con sus cítaras cuadradas y ahora seguiremos con los instrumentos de los folios 3r. $.^{\circ}, 5 \mathrm{r} .^{\circ}, 7 \mathrm{v} .^{\circ}, 18 \mathrm{v} .^{\circ}$, $23 v^{\circ}$ y $449 v .^{\circ}$ (este último ya mencionado con motivo de la danza en círculo). En la iluminación del $3 r^{\circ}{ }^{\circ}$ se encuentra el rey David en su trono frotando las cuerdas de un instrumento de perfil entallado, pero está tan inhábilmente elaborado que apenas se percibe su contorno, salvo el largo arco. De todas formas, creemos que es similar a los ya vistos en los códices Barberini y Theodore. Junto a él otro músico sostiene unos címbalos, mientras un danzarín evoluciona con un traje de mangas muy largas 


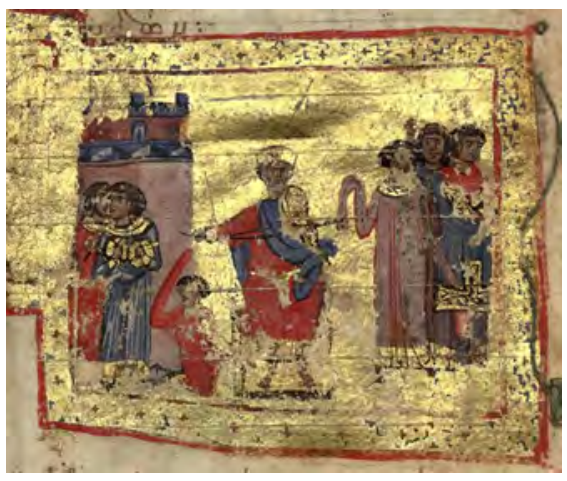

Lám. 40. Salterio griego de 1059. Biblioteca Vaticana, gr. 752 , fol. 3r. ${ }^{\circ}$ ().

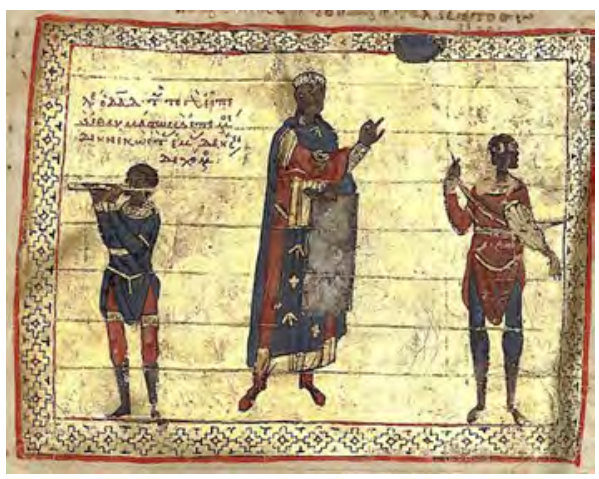

Lám. 41. Salterio griego de 1059. Biblioteca Vaticana, gr. 752, fol. 23v. ${ }^{\circ}$ ().

para hacerlas girar en el aire en torno a su cabeza, al igual que otra figura a la derecha de la imagen (lám. 40). Las mangas serían el equivalente para los hombres de los velos y cintas que hemos visto en manos de las mujeres danzarinas. En cambio, en el folio $23 \mathrm{v}^{\circ}$ el monarca está de pie con un rollo abierto que sostiene su mano izquierda, mientras que con la derecha hace signos quironímicos a un músico que frota con un gran arco una fídula de similar contorno entallado, tan mal dibujada como la anterior, cordófono que se combina con la flauta travesera de otro músico a la izquierda (lám. 41).

Estos cordófonos de caja entallada, cuerdas frotadas y clavijero en canal con clavijas laterales, que estamos viendo en estos códices del siglo XI, y que ya no volveremos a encontrar hasta el siglo $\mathrm{XVI}^{102}$, pensamos que pueden proceder de instrumentos armenios de época anterior, pues en una excavación de Dvin (la antigua capital de Armenia) apareció un vaso de vidrio, fechado por los arqueólogos entre los

${ }^{102}$ En las pinturas murales de las iglesias de los monasterios del Monte Athos, como el de Stravronikita, se pueden ver de nuevo estos cordófonos entallados, con su especial clavijero en forma de canal y de argolla de madera con clavijas laterales, una tipología de clavijero no vista en Occidente. Esto quiere decir que, aunque este modelo no haya aflorado en la iconografía de los siglos intermedios (XII, XIII y XIV), debió seguir en uso en determinadas zonas del imperio. Cfr. Anoyanakis, op. cit., lám. 61. Asimismo, J. Braun en su citado artículo «Musical instruments in Byzantine illuminated manuscripts», p. 320, recoge una miniatura de un Salterio de la Biblioteca Patriarcal de Jerusalén, el Taphou 86, copiado por Manolios Grigoropoulos y fechado en 1503, donde aparece el rey David como constructor de instrumentos, papel que le ha asignado el salmo apócrifo 151. Curiosamente, en esta imagen se ve al monarca con barba y con corona en su papel de juventud como pastor, rodeado del ganado, mientras que en sus manos sostiene una fídula entallada, del tipo que estamos viendo, con su clavijero en forma de argolla y con clavijas laterales. En la otra mano exhibe un cuchillo con el que talla la caja de madera del instrumento. A pesar de que la miniatura está solo dibujada y no coloreada, la iconografía es muy significativa, por ser única, o al menos así lo creo. 


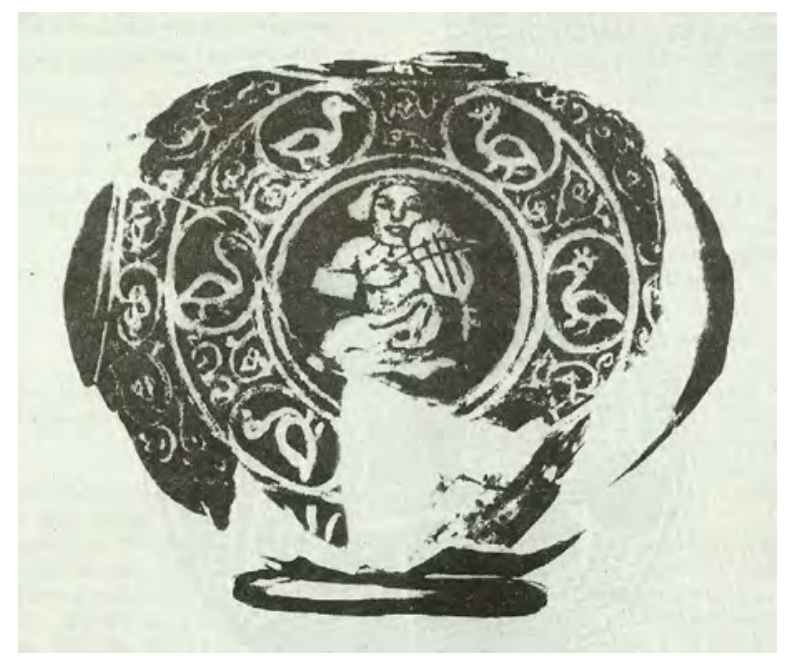

Lám. 42. Vaso de vidrio (siglos IX-x) hallado en la excavación de Dvin (Armenia).

siglos IX y $\mathrm{x}$, donde se encuentra un músico frotando las tres cuerdas de un pequeño cordófono similar, llamado djut’ak en la lengua autóctona (lám. 42) ${ }^{103}$. Su cronología coincide con la del Libro de las Lamentaciones del poeta armenio Gregorio de Narek (950-1003), donde habla de un instrumento de «sonido nuevo» ${ }^{104}$. Que se haya incorporado ahora al instrumentario bizantino un instrumento de origen armenio no nos debe extrañar en una época en la que tanto emperadores como funcionarios y, sobre todo, gran parte del ejército tenían esta procedencia.

Y si estas son pequeñas miniaturas que salpican estas páginas aquí y allá, existe una mucha mayor muy interesante, la que ocupa el folio $18 \mathrm{v}^{\circ}$, que está presidida por Jesucristo en lo alto, sentado en un trono, y debajo David dentro de

103 Fue estudiado y publicado por A. Tsitsikin,, «The earliest Armenian representations of bowed instruments». RidIM Newsletter, vol. 16, núm. 2 (1991), pp. 2-4. La tipología de la caja de este cordófono es exactamente igual que la aparecida en una figurita de terracota hallada en Pachal-tepe, Oasis de Kaschkadarja, Rayon Jakkabag (Uzbekistán), de la cultura de Sogdia, siglos inI-Iv d.C., y que publicamos en nuestro artículo sobre «Iconografía de la 'guitarra' medieval, su origen centroasiático y su derivados europeos", en El sonido de la piedra. Actas del Encuentro sobre instrumentos en el Camino de Santiago, Xunta de Galicia, Santiago de Compostela, 2005, pp. 223-280, lám. 7. No tiene nada de particular, pues, que a estos cordófonos punteados cultivados en el Asia Central, al sur del mar de Aral, se les haya aplicado un arco en torno al primer milenio y que hayan viajado hacia el oeste y enraizado en la cultura armenia, ya como cordófonos frotados, o bien que haya sido en la propia Armenia donde se le dotó del arco, según nos muestra el vidrio aparecido en Dvin.

104 Ibidem, p. 3; W. Bachmann, The Origins of Bowing..., p. 41 y ss, consideraba la zona del Asia Central como el núcleo originario del arco, aunque sin imágenes que lo probaran, pero sí aportaba referencias documentales y otras evidencias. 


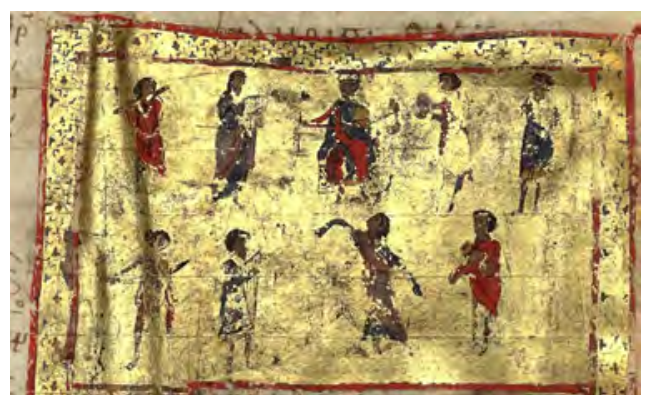

Lám. 43. Salterio griego de 1059. Biblioteca Vaticana, gr. 752 , fol. 5r. ${ }^{\circ}$ (C)

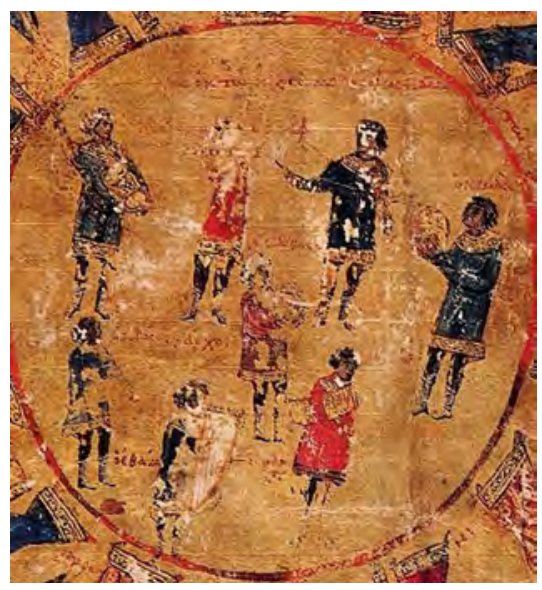

Lám. 44. Salterio griego de 1059. Biblioteca Vaticana, gr. 752 , fol. $449 v^{\circ}{ }^{\circ}$ ().

un templete. Varios personajes ocupan diferentes lugares, entre ellos músicos de trompeta, flauta travesera y arpa-cítara, pero la miniatura está tan deteriorada y con tanta pérdida de pintura que hemos optado por no mostrarla. Sí, en cambio, lo hizo Tilman Seebass ${ }^{105}$.

Además de todos estos folios, existen otros dos importantes en los que se reúne en torno al monarca un nutrido grupo de músicos con instrumentos diferentes. La primera imagen se encuentra en el fol. $5 r^{\circ}$, donde vuelve a aparecer David entronizado con un cordófono frotado entre sus manos (lám. 43). Cuatro músicos lo rodean con flauta travesera, el falso modelo de salterio cuadrado, címbalos y un aerófono no identificado. Debajo, y en torno a la figura de Míriam, que danza con esas mangas largas que ya hemos visto antes, se disponen otros tres músicos con otro cordófono de arco y un arpa-cítara. El último porta un rollo, dando a entender que era el director de esta pequeńa banda. Los mismos siete músicos al mando del que sostiene el rollo se han introducido en la famosa miniatura del folio 449v. ${ }^{\circ}$ (lám. 44), aunque los instrumentos varían un tanto. Arriba, y de izquierda a derecha, vemos un tambor cilíndrico profundo exhibiendo sus dos parches, una flauta travesera, una lyra bizantina frotada con un largo arco y unos címbalos, mientras que abajo figura en primer lugar una corneta y luego una gran arpa-cítara, con las cuerdas más graves pegadas al cuerpo del músico. En el centro hay otro con un instrumento imposible de identificar por pérdida de pintura. En suma, dos conjuntos importantes de instrumentistas que nos serían de mayor utilidad si no estuvieran las miniaturas tan deterioradas. 


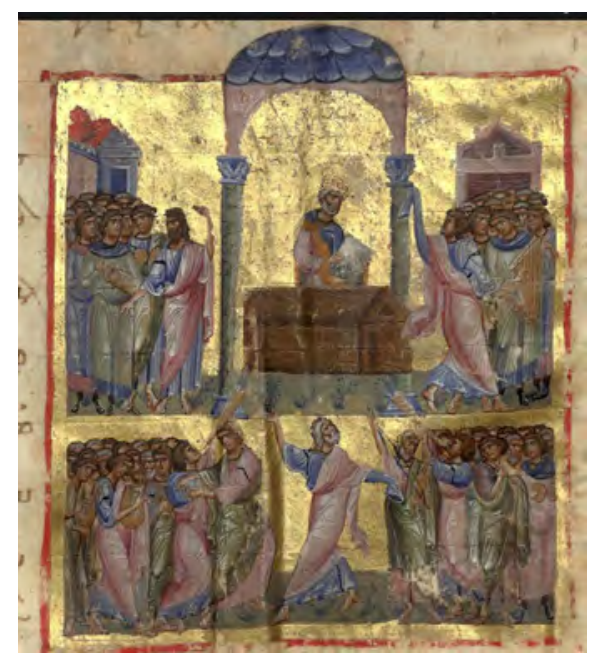

Lám. 45. Salterio griego de 1059. Biblioteca Vaticana, gr. 752, fol. 7v. ${ }^{\circ}$ (

Pero, aparte de estos folios que, a pesar de todo nos han proporcionado una información valiosa sobre la forma de trabajo en los scriptoria, mezclando instrumentos coetáneos con los falsos salterios cuadrados, por ejemplo, este manuscrito nos depara la magnífica imagen del folio $7 \mathrm{v}^{\circ}{ }^{\circ}$ (lám. 45), que ha sido elaborado evidentemente por otro miniaturista más diestro, con unas pinturas de mejor calidad que las utilizadas por sus colegas en los folios anteriores. Aparte de esto, ha hecho uso de una técnica similar a la de los miniaturistas occidentales, sorprendiéndonos de él la correcta construcción espacial, su intento de conseguir perspectiva con la disminución del tamaño de los personajes más alejados y la inclusión de arquitecturas en los fondos, la preocupación por el volumen de las figuras y por el diestro manejo de los pliegues de sus vestiduras y, sobre todo, por los instrumentos que incluye en la composición.

Se trata de una página con dos registros. En el superior David coronado se encuentra junto al Arca de la Alianza bajo un arco de medio punto sostenido por columnas con capiteles corintios, que culmina una pequeńa cúpula de placas de pizarra azules. A un lado y a otro se han dispuesto grupos de figuras que representan a los israelitas, precedidos por instrumentistas y bailarines. En el grupo de la derecha, vemos en primer plano un arpa-cítara y tras ella una flauta travesera, además de un danzarín, quien con sus mangas largas evoluciona frente a sus compañeros. En el de la izquierda, un tambor de cilindro largo, pero de corto diámetro, percutido por una baqueta de punta doblada, como las ya vistas, además de unos címbalos que quedan medio ocultos tras otro bailarín de movimientos menos exagerados, que lleva en sus manos un idiófono entrechocado, quizás una especie de çarparas. En el registro inferior nos encontramos ahora al rey David sin corona realizando una danza sagrada delante del Arca, con una de las mangas de la túnica muy larga, 
mientras el otro brazo queda al descubierto. A un lado y a otro suyo, de nuevo grupos de músicos con grandes trompas que, dirigidas a lo alto celebran el acontecimiento, al mismo tiempo que otro danzarín entrechoca unos cheirocymbalos, y otros dos puntean las cuerdas de laúdes cortos, uno de ellos voluminoso como el laúd árabe. Junto a ellos otros músicos entrechocan címbalos o soplan una flauta travesera. Pero lo más significativo de esta miniatura desde el punto de vista instrumental son los dos cordófonos, que, situados a la izquierda y la derecha en un primer plano, nos sorprenden grandemente. El de la izquierda se puntea y el de la derecha se frota con un largo arco, que obliga al músico a extender el brazo derecho hacia lo alto lo máximo posible. Se trata del $c r w t h$ de las Islas Británicas, cuyo ámbito de expansión no fue muy grande en la Edad Media, pues quedó confinado a estas islas, con alguna presencia en imágenes francesas. En el ámbito anglosajón pervivió hasta el siglo XIX y hoy en día, con el interés que existe por recuperar lo autóctono, se ha resucitado. Lo vemos en códices ingleses de la primera mitad del siglo XI, como en uno de Cambridge (UL. F f I 23) o en otro francés conservado en Klosterneuburg (Stifts-M, ms. 987). Se podría pensar a la vista de esto que el instrumento pudo llegar a Oriente con motivo de las Cruzadas, pero la primera no comenzó hasta 1096, por lo que hemos de descartar esta vía y pensar en otro tipo de trasmisiones. Ya hemos dicho que esta miniatura es especial dentro del Salterio 752, por lo que bien podría haber sido confeccionada por algún monje occidental en el scriptorium donde se realizó, que debió ser lo más probable por la buena calidad de la miniatura. Otra opción en la que podríamos pensar sería que se hubiera copiado de algún códice llegado de Occidente. De todas formas, lo que sí está claro es que el crwth no era un instrumento bizantino y que su presencia aquí se debe al interés del miniaturista por mostrar un variado número de instrumentos, quizás también de otras culturas. Lo decimos por la presencia también del laúd árabe, interés que comparte con determinados miniaturistas occidentales.

Pasados un par de siglos, ya en el período paleólogo, volvemos a encontrar un códice que reproduce el crwth (el Salterio n. ${ }^{\circ} 3$ del Museo Histórico de Moscú, fol. $1 \mathrm{v}^{\circ}$ ) con dos tipologías diferentes (lám. 46): la de lados rectos, derivada del tipo de lira anglosajona, como la hallada en la tumba real de Sutton Hoo (año 670 d.C.), y reproducida en varios manuscritos ingleses (Cotton Vespasiano I, fol. 30v. ${ }^{\circ}$, por ejemplo), y la de contorno entallado con la típica forma de candado, llamada lira redonda, que fue la que se desarrolló más tarde en Francia y centro de Europa, según vemos en un Salterio de la escuela de Reichenau del Museo Arqueológico de Cividale (siglo $\mathrm{x}$ ) o en un Breviario del siglo XI (fol. 44v. ${ }^{\circ}$ de la Biblioteca Vaticana, pallat. 39), procedente de Michelberg/Heidelberg ${ }^{106}$. El manuscrito ruso está fechado entre 1270 y 1296, lo cual podría hacer viable la presencia de este instrumento en Oriente, pero aun así creemos que proviene, al igual que el crwth del ms.752 de la Vaticana, de la copia de algún códice.

106 R. Álvarez, «Presunto origen de la lira grabada en una estela funeraria (ca. s. viII a.C.) encontrada en Luna (Zaragoza)». Revista de Musicología, vol. viıI, núm. 2 (1985), 1985, p. 219 y ss. 


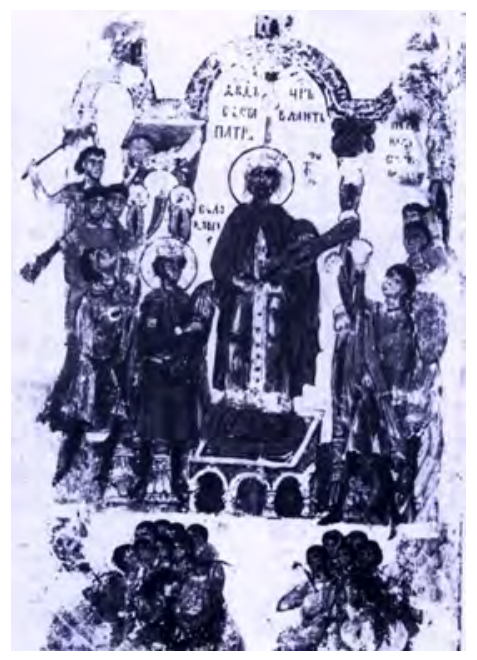

Lám. 46. Salterio n. 3 del Museo Histórico de Moscú, fol. 1v..

Dorota Poplawska ${ }^{107}$ comenta que el códice fue realizado en Rutenia por artistas locales, con quienes colaboró alguno occidental, lo cual explicaría la presencia de estos cordófonos y también de aquel que está en manos del rey David, que es nada menos que un organistrum, es decir, un cordófono de cuerdas frotadas por una rueda, característico del Occidente europeo (Francia y la Península Ibérica, primordialmente) en los siglos XII y XIII, presente en varios pórticos románicos, como el de la Gloria de Santiago de Compostela, por ejemplo, y que nunca se cultivó en Oriente. Se trata de un modelo primitivo construido para ser manejado por dos intérpretes, pero aquí es solo el monarca el que desempeña ambas tareas: hace girar la manivela que mueve la rueda con la mano derecha, mientras que con la izquierda manipula las palancas que actúan de teclas. La caja tiene forma de ocho, con dos oídos de media luna cerca de los hombros. Otros músicos en torno suyo tocan una trompeta cónica, como la tuba romana, címbalos y un tambor con larga baqueta, es decir, instrumentos más comunes en este ámbito. La miniatura presenta problemas de conservación, pero pese a ello no nos resistimos a reproducirla, por la singularidad de estos instrumentos en un entorno tan alejado de su foco de origen. Hemos tomado la imagen del articulito ya citado de la investigadora polaca Dorota Poplawska, quien no ha reconocido la naturaleza e importancia de los mismos. Al crwth lo denomina zither y al organistrum lo pasa por alto, seguramente porque no lo había visto nunca ni sabía lo que era.

107 D. PoplawsKa, «String in Medieval Russia». RIdIM Newsletter, vol. 21, núm. 2 (1996), pp. 63 y 65. 


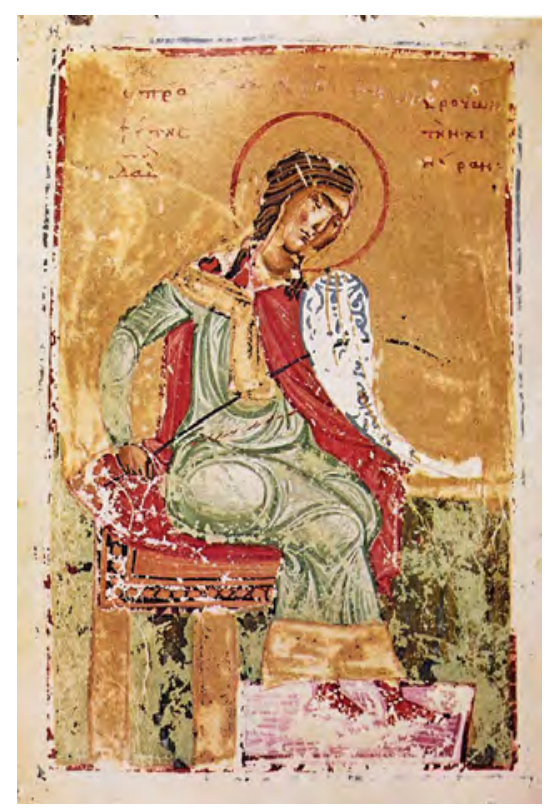

Lám. 47. Salterio del monasterio de la Gran Laura del monte Athos (B 26) dek siglo XI, fol. 209v. .

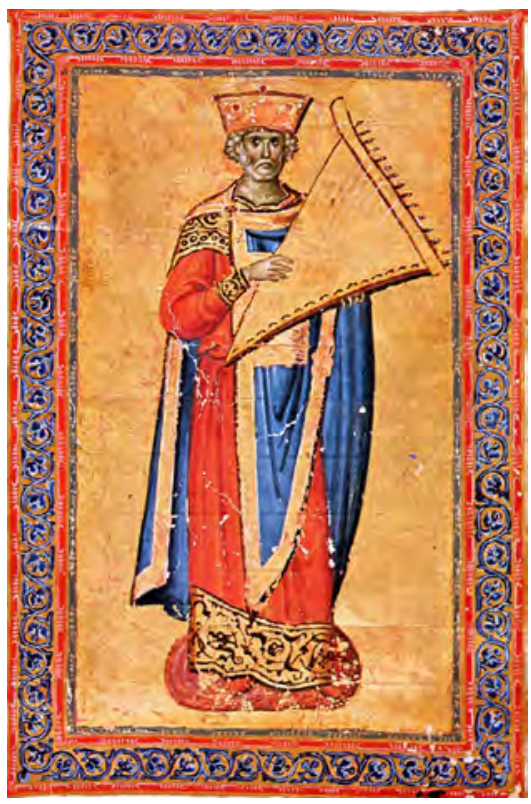

Lám. 48. Salterio del monasterio Stravronikita, en el monte Athos, cod. 911 , del siglo XII, fol. $2 \mathrm{v}^{\circ}$.

Y volviendo a finales del siglo XI, tenemos que señalar que es en estos momentos cuando se crea una iconografía del rey David en su trono, casi siempre solo tocando un cordófono o con dos músicos, imagen ya bastante grande que va a ocupar una página completa, y que André Grabar califica de retrato del monarca bíblico. Este nuevo modelo se puede ver en códices de la siguiente centuria procedentes casi todos de scriptoria de Palestina o de otras zonas del imperio, algunos estudiados por Annemarie Weyl Carr ${ }^{108}$. En primer lugar, mencionemos la imagen de David sobre un sencillo trono, tañendo una lyra bizantina con un gran arco (lám. 47), que se muestra en el fol. 209v. ${ }^{\circ}$ de un Salterio de fines del siglo XI del monasterio de la Gran Laura del monte Athos (B 26). Y también de otro monasterio del Athos, esta vez del Stravronikita (códice 911, fol. 2v. ${ }^{\circ}$ ), es el monarca que aparece de pie con gran capa azul sobre túnica roja, sosteniendo entre sus brazos una gran arpa-cítara de 14 cuerdas, el kanonaki, que muestra sus dos travesaños en ángulo, su clavijero y los puntos de sujeción de las cuerdas en la caja (lám. 48). Son ambos instrumentos característicos de este mundo musical griego que ya está consolidado.

108 A. Weyl Carr, «A group of provincial manuscripts from the twelfth century». Dumbarton Oaks Papers, núm. 36 (1982), pp. 39-81, láms. 35, 47, 48, 49 y 50. 


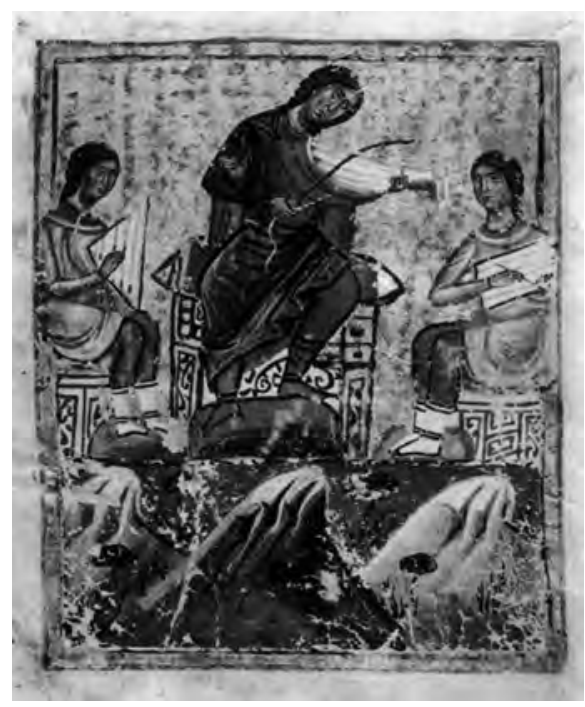

Lám. 49. El rey David con dos de sus músicos. Códice del siglo Xiı. París, Bibl. Nat. Suppl. gr. 1335, fol. 258v. ${ }^{\circ}$.

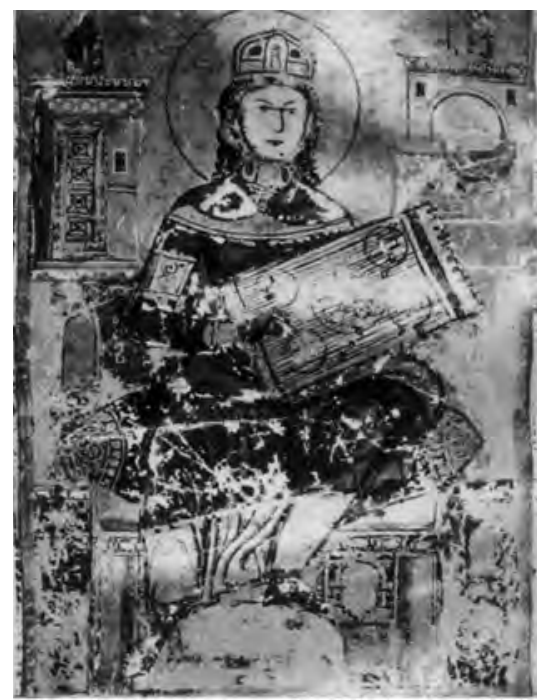

Lám. 50. El rey David del manuscrito Vatopedi 851, fol. $123 \mathrm{v} .^{\circ}$ del monte Athos.

Por otra parte, los manuscritos provinciales estudiados por Weyl Carr nos ofrecen otros seis instrumentos interesantes: un laúd de tipo árabe (London, British Library, Add. 40733), la lyra bizantina de nuevo, pero ahora de perfil, con su dorso abombado y su clavijero doblado en ángulo separado del mango por una pieza circular (París, Bibl. Nat. Suppl gr. 1335, fols. 258v. ${ }^{\circ}$ y $260 v .^{\circ}$ ), el arpa-cítara y salterios rectangulares. Y es que el citado folio $258 \mathrm{v}{ }^{\circ}$ del códice de París muestra al monarca con el tipo de lyra bizantina descrita más arriba, flanqueado por dos músicos que tocan el arpa-cítara, como esquema representativo del salterio triangular simbólico y un salterio rectangular del mundo fatimita que representa el tipo de salterio cuadrado que ya vimos, con todas sus connotaciones simbólicas (lám. 49). Quiere decir esto que ya los miniaturistas en estos momentos habían abandonado las formas vacías y equívocas del triángulo y del cuadrado para referirse a los textos de los Santos Padres en sus comentarios a los Salmos y los sustituían por instrumentos reales, cuyos contornos se asemejaban ${ }^{109}$. Desde luego, lo más interesante de estos códices es el salterio rectangular, tipo qânum egipcio, del manuscrito Vatopedi 851, fol. $123 \mathrm{v}^{\circ}{ }^{\circ}$ del monte Athos (lám. 50), porque muestra cinco rosetones en la tabla de armonía, exactamente igual que los que se ven un siglo después en la miniatura de la

109 R. Álvarez, «El arpa-cítara bizantina...», pp. 18 y 19. 


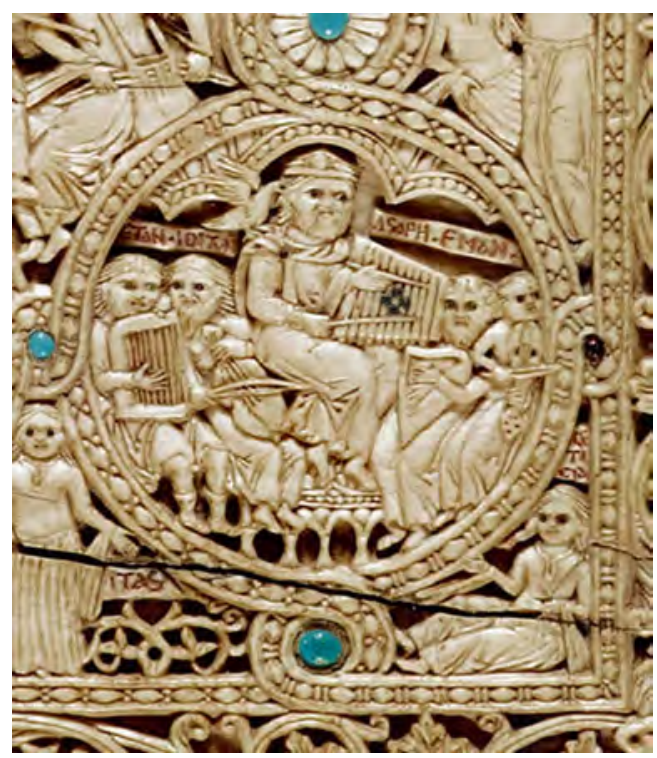

Lám. 51. Detalle de la tapa de marfil del Salterio de la reina Melisenda de Jerusalén, 1. ${ }^{a}$ mitad del siglo XII. Museo Británico, codex Egerton 1139.

cantiga 80 del códice b I 2 de las Cantigas de Alfonso X el Sabio del monasterio de El Escorial (año 1284), lo que nos seńala la procedencia de estas bellas decoraciones, que solían hacerse de pergamino, sobre los necesarios oídos.

Dejando por un momento la miniatura, que tantos ejemplos musicales nos ofrece, y antes de finalizar este largo apartado del rey David con la interesantísima miniatura del Salterio Hamilton ya tardío, queremos hacer mención a una pieza singular de marfil: las tapas del Salterio de la reina Melisenda de Jerusalén (Museo Británico, codex Egerton 1139), quien reinó entre 1131 y 1153, donde también se ha labrado en uno de sus medallones al monarca bíblico David sentado en su trono y rodeado por sus cuatro músicos, cuyos nombres aparecen en cartelas sobre sus cabezas: Ethan, Idithun, Asaph y Eman se lee de izquierda a derecha (lám. 51).

Durante su reinado, esta activa reina medieval encargó el Salterio que lleva su nombre, que más que por el propio códice en sí ha adquirido fama por la cubierta de marfil que se confeccionó para él en un taller de Jerusalén, a la que se añadieron esmeraldas, amatistas, turquesas y otras gemas, como se puede comprobar en la imagen. En ella intervinieron artistas bizantinos y alguno occidental. Y en verdad que los cinco instrumentos son de un lado y del otro del Mediterráneo. David está golpeando con dos palillos simples las cuerdas de un santir o santur persa, es decir, una cítara de tabla con su característica forma de trapezoide simétrico y su pequeño rosetón en la tabla de armonía. Es la primera vez que nos encontramos con esta tipología, que debía estar ya difundida por el Oriente Próximo, pues a la Península Ibérica nos llega a fines del siglo XII, según se ve en algunos pórticos, como el de 
Santo Domingo de Soria. Una buena imagen suya es la que muestra la Cantiga C del códice T I 1 de las Cantigas de Alfonso X el Sabio del monasterio de El Escorial, de 1283. A la derecha vemos una lyra bizantina de clavijero plano en forma lanceolada con su cordal trapezoidal, sus dos oídos semicirculares y sus cuatro cuerdas, que son frotadas con un pequeño arco. Es el cordófono que nos vamos a encontrar en Europa en muchísimos ejemplos. Contrasta esta forma de pera del cordófono de Eman con la de contorno de 8 de Idithum en el lado opuesto, que se toca a la manera oriental (árabe), apoyando el instrumento sobre una de las rodillas del músico. Su mango es corto, su clavijero poligonal y trapezoidal su pequeño cordal, donde se anudan las tres únicas cuerdas que posee. Es un modelo que también encontramos en Occidente con frecuencia. Por su parte, a Asaph se le ha adjudicado un arpa occidental, del tipo románico, mientras que el problema de identificación se presenta con el arpa abierta de Ethan, que quizás aluda al chang persa que vemos en otras miniaturas y que por la estrechez del espacio el eborario ha tenido que circunscribirse a esa forma un tanto rectangular. Aun así, creemos que es un interesante conjunto que nos habla de la mezcla de instrumentos orientales y occidentales que debía haber en la Jerusalén del siglo XII.

Esa simbiosis de culturas que nos muestra el marfil es mucho más acusada en la miniatura del rey David que ilustra el Salmo 151 en el folio 41v. ${ }^{\circ}$ del Salterio Hamilton (Berlín, Staatliche Museen, Preußischer Kulturbesitz, Kupferstichkabinett 78.A.9), fechado a finales del siglo xIII o comienzos del XIV en Chipre, y que constituyó el tema de la tesis doctoral de la profesora Christine Havice ${ }^{110}$. Al parecer, este códice bilingüe (griego y latín) se confeccionó en un scriptorium de Chipre y fue propiedad de Carlota de Lusignan, aspirante al trono de esta isla en 1458. Era una gran bibliófila, afición que compartió con el papa Inocencio VIII, y cuando se exilió a Roma se llevó consigo el manuscrito, que estuvo en diversas bibliotecas de Italia hasta que lo adquirió el décimo duque de Hamilton en el siglo XIX, quien acabó donándolo, junto con otra serie de manuscritos, al Museo de Berlín.

La miniatura de este folio 41v. ${ }^{\circ}$ (lám. 52) presenta a David bajo doble arco en medio de colinas y árboles, y esparcidos por el suelo una serie interesantísima de instrumentos de variada tipología y origen que aluden al texto del versículo 2 del propio salmo escrito bajo los arcos: "Mis manos fabricaron un instrumento, mis dedos ajustaron un salterio». $\mathrm{Y}$ en efecto, el miniaturista ha puesto en manos del monarca, que va revestido con una túnica roja enriquecida con elementos bordados en oro, un salterio en forma de triángulo equilátero, con las cuerdas paralelas a la base del mismo que queda en la parte superior pegada a su pecho.

Se trata sin duda del salterio simbólico, del que ya hablamos anteriormente, y en este caso su contorno triangular alude a la Trinidad. Dispersos por el prado vemos un órgano de tamaño mediano con tres hileras de tubos (jla cuarta imagen

${ }^{110}$ Ch. Havice, The Hamilton Psalter in Berlin. Kupferstichkabinett 78.A.9, University Park (Pensilvania), 1978; $y$ «The marginal miniatures in the Hamilton Psalter (Kupferstichkabinett 78.A.9.)». Jahrbuch der Berliner Museen, vol. xxvi (1984), pp. 79-142. 


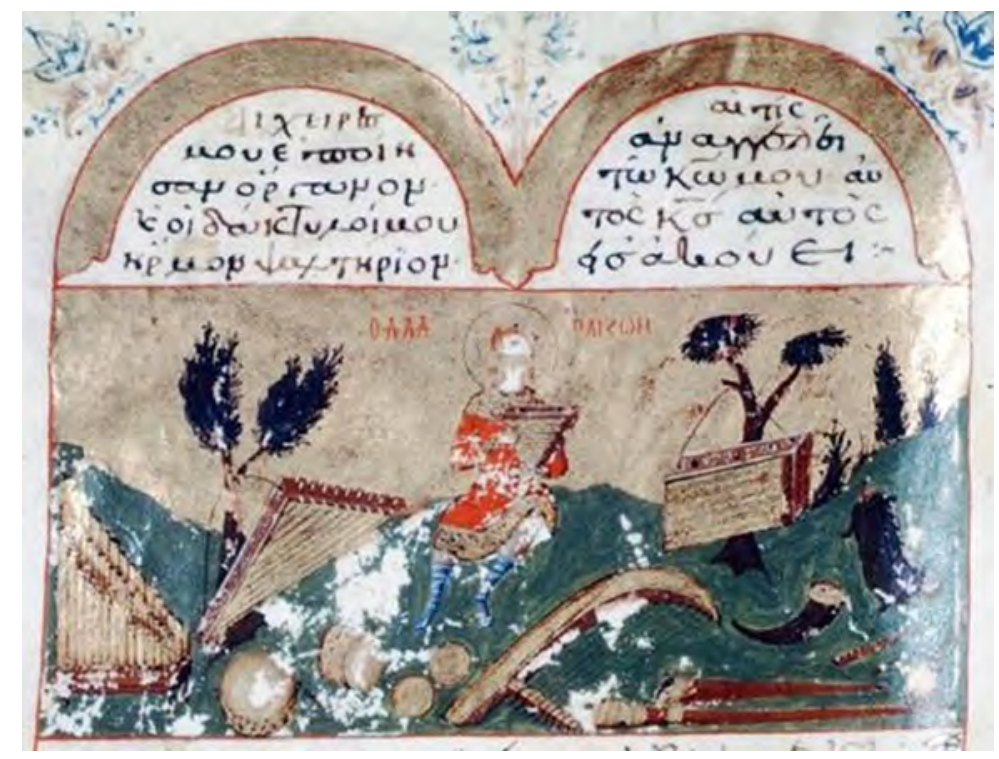

Lám. 52. Salterio grecolatino Hamilton de fines del siglo xıII, fol. 41v. ${ }^{\circ}$. Berlín, Museo Estatal. David del salmo 151.

que tenemos de él!) ${ }^{111}$; un arpa-cítara colgada de un árbol, con cuerdas por ambos lados, según comprobamos por la disposición de las clavijas; un par de tambores de cilindro mediano, cubierta la caja en el de la izquierda por una especie de redecilla; unos címbalos de tamaño mediano; un gank árabe o chang persa perfectamente dibujado, es decir, un arpa abierta con la caja de resonancia curvada por la parte superior, que era de piel, y prolongada más abajo del clavijero, que es recto y muestra los amarres de las diez cuerdas; un salterio rectangular colgado de un árbol con cinco rosetones, como el visto en la lám. 50, y cinco coros o grupos de cuerdas; un cuerno; dos trompetas cónicas en el suelo; una flautilla popular, posiblemente un salamouri o flauta georgiana; un changuri (simple cordófono de caja circular muy plana, con tapa de piel y una o dos cuerdas) ${ }^{112}$; y un chibodi (gaita también de esta zona) muy parecido a la tsambouna de Grecia, es decir, confeccionado con una piel

111 Es significativa esta imagen del órgano en una época en la que, según N. Maliaras, op. cit., pp. 264-286, había desaparecido de la vida de la corte, pues en el De Officiis (mitad del siglo xIV) de Pseudo-Kodinos, que es el equivalente al Libro de las Ceremonias del período macedonio, ya no se le nombra. Al parecer esto vino a suceder después de que Miguel VIII de la dinastía paleóloga subiera al trono en 1261. Él lo achaca a varios factores ligados directamente con la corte, pero está claro que el órgano se siguió utilizando en otros ambientes y áreas geográficas.

112 Cfr.: http://instrumundo.blogspot.com.es/2012_09_30_archive.html. 
de cordero que queda siempre bien inflada con la forma del cuerpo del animal ${ }^{113}$. Lleva un soplador y en el otro lado un tubo cantante, algo que en esta miniatura, que ha sufrido grandes pérdidas de pintura, no se percibe. Lo mismo pasa con el chianuri, que justamente tiene un reflejo del flash sobre su caja y apenas se ve. Solo lo hemos detectado en fotos en blanco y negro. Estos tres últimos instrumentos son típicos de la región de Georgia, quizás un guiño del miniaturista, que procedía de esta zona y los ha confinado al extremo derecho de la imagen. Por tanto, aquí se han combinado instrumentos propiamente bizantinos (órgano, arpa-cítara, tambores, címbalos y trompetas) con aquellos procedentes del mundo islámico (salterio rectangular egipcio y arpa persa), además de instrumentos populares de zonas muy alejadas del scriptorium donde se confeccionó el códice, como era Georgia. Esto sin contar con el falso salterio triangular ${ }^{114}$. Que se trata de un salterio simbólico y no de un instrumento real lo demuestra el instrumento que porta David en el traslado del Arca de la Alianza, donde camina rodeado por otros músicos, llevando en sus manos un instrumento similar, pero invertido, en las pinturas del siglo xvi de la bóveda del santuario del khatolikon en el monasterio de Stravronikita, en el monte Athos. Si fuera un instrumento real, su forma de tocarlo sería siempre la misma.

\subsubsection{Los comentarios del Pseudo-Nonnus}

Este es un texto que por su contenido se ha prestado a la representación de instrumentos musicales, porque habla sobre algunos temas mitológicos de la Antigüedad, en los que hacía acto de presencia la música. Este texto se solía añadir como apéndice a los códices que contenían las Homilías de san Gregorio Nacianceno. El manuscrito más antiguo que contiene estos textos es el aristocrático de la Biblioteca Nacional de París 510, cuyas miniaturas, como ya vimos con relación a la danza de Míriam, están en muy mal estado. Ahora, para ejemplificar este tema, queremos mostrar una única miniatura del códice conservado en la Biblioteca del Patriarca de Jerusalén, que ha sido estudiado por Joachim Braun en el artículo ya mencionado ${ }^{115}$. Se trata del códice Taphou 14, miniado en Constantinopla en el siglo XI, que se conserva bastante bien y que muestra en varios folios diversos instrumentos musicales, si bien muy esquematizados, con formas geométricas de cuadrados o de triángulos rectángulos, que aluden a los salterios simbólicos de los que ya hemos hablado, y también algún cordófono frotado de caja entallada como los ya vistos (fols. 100r. ${ }^{\circ}, 102 r^{\circ}{ }^{\circ}$ y $\left.103 r .{ }^{\circ}\right)$. En cambio, los representados en el folio $310 v^{\circ}{ }^{\circ}$ se conservan en un estado aceptable y son perfectamente reconocibles ${ }^{116}$. En

${ }^{113}$ Cfr.: http://instrumundo.blogspot.com.es/search/label/Chiboni.

114 Falsos salterios de este tipo pueden verse en el pórtico del Paraíso de la catedral de Orense en el siglo XIII, es decir, por las mismas fechas que este códice.

$115 \mathrm{~J}$. BraUn, «Musical instruments in Byzantine illuminated manuscripts». pp. 316-318. láms. 6 y 10.

116 También incluye los folios 100r. ${ }^{\circ}$ y 310v. ${ }^{\circ}$ W. Bachmann en The Origins of Bowing..., 


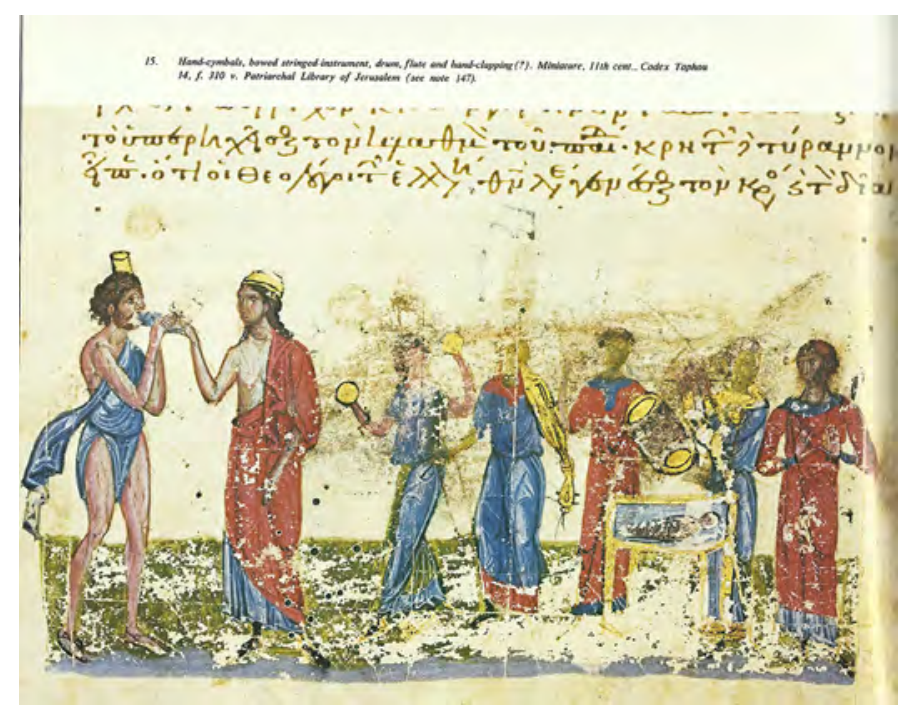

Lám. 53. Homilías de san Gregorio Nacianceno, códice Taphou 14, fol. 310v.․․ Biblioteca del Patriarca de Jerusalén.

esta última miniatura se habla del nacimiento de Zeus y en ella se ha dispuesto en medio de un paisaje irreal, y junto a la cuna del recién nacido, a cinco coribantes: una mujer con címbalos danzando, un tańedor de fídula con una caja muy estrecha y entallada, corto mástil y clavijero en canal, que, a pesar de su visión alargada, se asemeja a la que veíamos en códices anteriores de procedencia armenia, un profundo y gran tambor y una flauta travesera (lám. 53).

El último personaje de la derecha, que tiene las manos en una postura extrańa, sobre el pecho, Braun lo considera el director de esta banda de músicos de tipo dionisíaco, según la terminología de la época, aunque Weiztmann ${ }^{117}$ piensa que debe estar tocando unos idiófonos entrechocados. La realidad es que no está tocando nada, porque tiene las manos extendidas y lo único que podría hacer es dar palmadas. Quizás, este historiador del arte no tuvo a mano una buena reproducción de esta miniatura. Este es un típico grupo de música dionisíaca, que Rhea, madre de Zeus, ordenó venir a Creta, donde tenía oculto a su hijo recién nacido, para que con el estruendo de los instrumentos Cronos no pudiera oír el llanto del niño y no se enterara de dónde estaba, puesto que venía a comérselo al igual que había hecho con los hijos anteriores de ambos ${ }^{118}$. Pero al fin lo descubrió y, según una de las versiones

117 K. Weitzmann, Greek Mythology in Byzantine Art. Princeton, Princeton University Press, 1951, pp. 38 y 49, lám. xiI, fig. 36.

118 J.P. Migne, Patrologia cursus completus. Series graeca. París, 1856-1866, vol. 36, col. 1065. Cfr. Anoyanakis, op. cit., nota 147, p. 367. 
del mito, se lo comió, momento que se representa a la izquierda de la imagen, en el que Cronos se mete en la boca al bebé Zeus y Rhea a su lado trata de impedírselo. Por tanto, los dos momentos de esta historia que se incluyen aquí deben leerse de derecha a izquierda. La historia viene narrada en el texto del Pseudo-Nonnus.

Existen otros códices que contienen las Homilías de san Gregorio y los Comentarios del Pseudo-Nonnus con el mismo conjunto musical, como el Vaticano gr. 1947 (fol. 146r. ${ }^{\circ}$ ) y el Panteleimon 6 del monte Athos, fol. 163r. ${ }^{\circ}$, según señala Braun y he podido comprobar, pero el color de estas miniaturas se ha perdido por completo y apenas son visibles los instrumentos. Aun así, Bachmann incorpora una a su libro ${ }^{119}$. Desde luego, es una temática poco frecuente que amplía el campo de imágenes musicales, tan escasas en estos siglos.

\subsubsection{La música vocal religiosa}

Hemos visto hasta aquí las distintas temáticas en las que hacen acto de presencia los instrumentos musicales, pero la música no solo fue instrumental, sino todo lo contrario: la música vocal era importantísima en el culto, así como en la vida de la corte y del pueblo, pero es imposible representarla, a menos que se haga con gestos del rostro o de las manos, y aun así puede resultar incomprensible o equívoca. Sin embargo, los artistas podían trasmitir lo que fue su presencia en los templos por medio de todo aquello que rodeaba a la liturgia, en la que los cantos eran su parte esencial, pero también se visualizaba el mobiliario litúrgico con los ambones para la colocación del coro, los atriles para los libros y los rollos, que recogían el repertorio vocal, etc. Asimismo, los pintores podían recrear las ceremonias por medio de las procesiones en el interior de los recintos sagrados y, sobre todo, los grupos de figuras que representaban al propio coro de voces, en las que podían distinguirse las distintas jerarquías de clérigos y cantores por sus vestimentas. Pero es que, además, los pintores bizantinos recogieron algo más importante, intrínsecamente hablando: las posturas de las manos y dedos del director del coro señalando por este medio las notas de la línea melódica. Era todo un lenguaje de signos llamado quironomía o quironimia el utilizado en el viejo rito bizantino, que ya estaba presente en el antiguo Egipto y que también fue usado en Occidente para el canto gregoriano. Esto permitió al destacado especialista en música bizantina Neil Moran ${ }^{120}$ conocer qué canto plasmaban los pintores en sus obras, a través de los signos que marcaba el director. Como se ve, era un lenguaje mudo muy expresivo.

Ante la existencia de tantas imágenes recogidas por Moran no solo de Bizancio sino también de los países eslavos que formaron parte de este imperio, nos ha parecido oportuno seleccionar dos de ellas como ejemplos de la música vocal en

119 Ibidem, lám. 12.

120 N.K. Moran, Singers in Late Byzantine and Slavonic Painting. Leiden, E.J. Brill, 1986. 


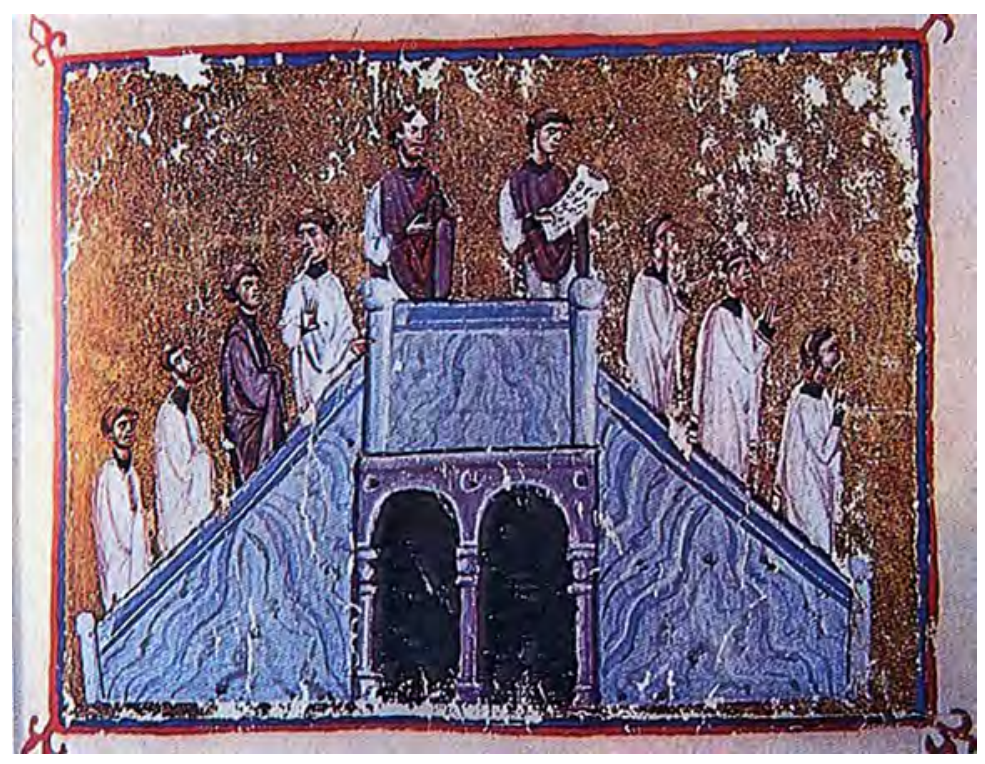

Lám. 54. Cantores en un ambón de un Evangeliario-Leccionario del monasterio Dionysiou, en el monte Athos, del siglo XI, códice 587 m, fol. 43.

los templos, una faceta importantísima de la vida musical bizantina de la que no habíamos hablado hasta ahora.

De todas las publicadas en el libro de Moran he escogido dos de las más antiguas, como paradigma de esta actividad musical que aún sigue vigente en la liturgia de la Iglesia ortodoxa. La primera seleccionada, por verse en ella un ambón, está extraída de un Evangeliario-Leccionario del siglo xi conservado en el monasterio de Dionysiou, en el monte Athos, codex 587 m, fol. 43 (lám.54). Aquí se ven nueve figuras tonsuradas, de las que siete están situadas en las escaleras del mencionado ambón, cuatro subiendo por la izquierda y tres descendiendo por la derecha, mientras en la zona más elevada se encuentran dos sacerdotes revestidos con phelonion (el equivalente a una casulla), uno de ellos con un rollo en la mano donde va escrito el texto del canto que se estaba interpretando, con su notación psáltica. Se trata de clérigos y cantores en el curso de un acto litúrgico de Cuaresma en el que cantan el himno (kontakion) «Akathistos». Moran ${ }^{121}$ deduce esto por la colocación de los cantores en la escena. De esta imagen está ausente la quironomía, porque el gesto de la mano de uno de los cantores que asciende se ha interpretado como un gesto pidiendo silencio.

${ }^{121}$ Ibidem, p. 150. 


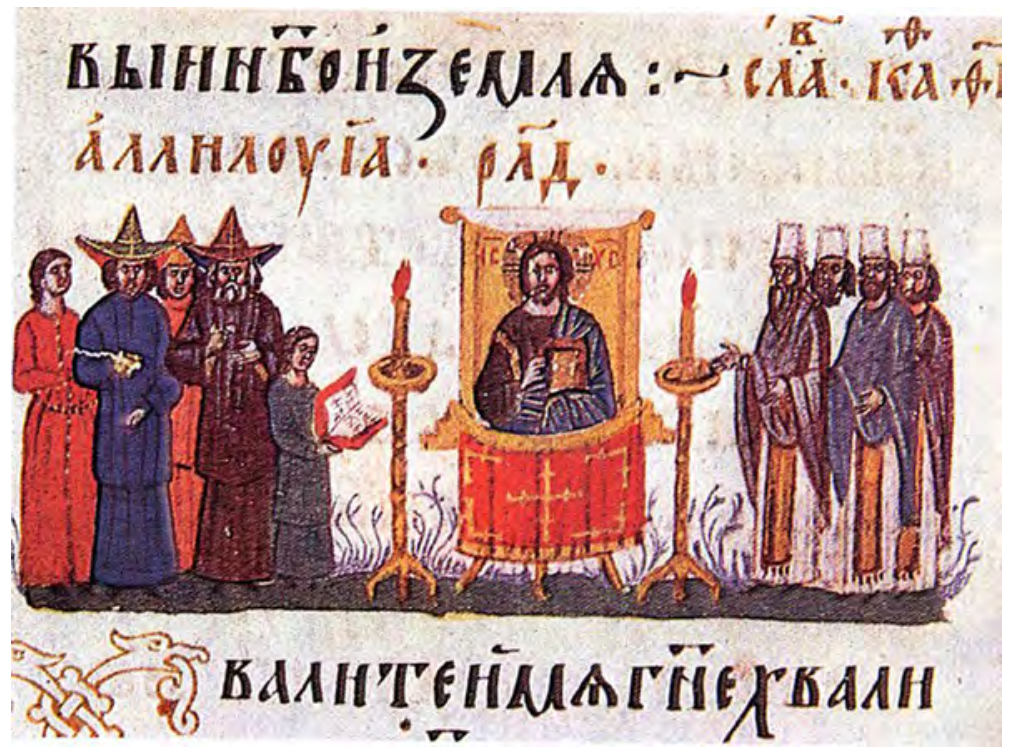

Lám. 55. Salterio Tomic, de ca. 1360. Museo Histórico de Moscú, fol. 226.

La segunda miniatura pertenece al Salterio Tomic, de ca. 1360 (Museo Histórico de Moscú), fol. 226, y está situada dentro del texto del Salmo 134 (lám. 55). En ella se representa de nuevo a un grupo de clérigos y psaltai (cantores) en torno a un icono con la figura de Jesucristo que está flanqueado por dos candelabros y un niño con un libro también en el curso de una ceremonia litúrgica. Los clérigos de la derecha van tocados con el kameloukion o bonete blanco, propio de su dignidad superior por pertenecer a la iglesia de Santa Sofía (sería negro si no lo fueran), mientras que los psaltai o cantores de la izquierda llevan sombreros rematados en pico y con alas. Aquí sí que vemos señales con los dedos de la mano derecha del cantor de traje talar azul, a la izquierda de la imagen, que al parecer está dirigiendo el coro.

\subsubsection{Alusión a la vida monástica}

Y, aunque fuera del contexto litúrgico de los templos, pero sí fundamental en la vida de los monasterios bizantinos, no queremos pasar por alto las imágenes encontradas en los salterios marginales del llamado semanterion o simantron, constituido por una tabla larga de madera que tenía buenas condiciones acústicas para sonar adecuadamente, al ser golpeada por dos martillos asimismo de madera por monjes expertos. Su sonido claro y limpio permitía que se le escuchara a larga distancia. Servía, como es obvio, para emitir con sus rítmicos toques y repicados las señales requeridas para congregar a los monjes a las distintas actividades de la vida 


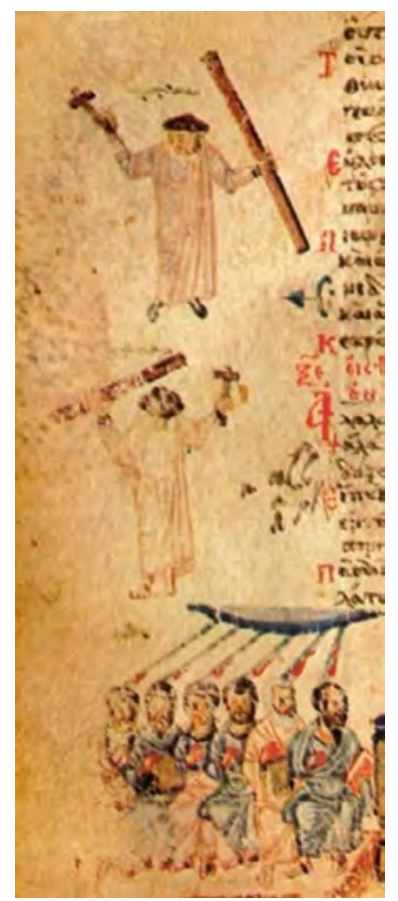

Lám. 56. Salterio Khludov, fol. 62v. ${ }^{\circ}$. Primera mitad del siglo IX.

Museo Histórico de Moscú.

monacal, a la misa y a las distintas horas del Oficio Divino distribuidas a lo largo del día. Todavía hoy se sigue utilizando. Era el equivalente de las campanas de Occidente. La primera imagen suya la vemos en el Salterio Khludov (fol. $62 \mathrm{v}^{\circ}$ ), donde dos clérigos con ellos en la mano se aprestan a golpearlos con sus correspondientes martillos. La miniatura tiene por tema principal la llegada del Espíritu Santo en forma de lenguas de fuego sobre las cabezas de los apóstoles (lám. 56). También se pueden ver en el Salterio Barberini (fol. 106r. ${ }^{\circ}$ ) y en el Theodore (fol. 80v. ${ }^{\circ}$ ).

$\mathrm{Y}$, aunque las grandes campanas no eran propias de Bizancio (otra cosa son las pequeñas o pequeñísimas campanas de las que tantos ejemplos hemos visto a lo largo de este recorrido), sí que hemos podido detectar un par de ellas en la crónica de los emperadores bizantinos de Juan Skytlizes (Biblioteca Nacional de Madrid, ms. 26-2), en su folio 144 b, donde se representa lo que podría ser una iglesia románica, que alude a Santa Sofía de Constantinopla. En su fachada vemos un campanario con dos campanas, prueba irrefutable de que esta copia de la crónica de los emperadores bizantinos fue elaborada en Occidente, en Sicilia concretamente, según opinan algunos estudiosos, y no en Constantinopla, donde no se usaban estos grandes idiófonos golpeados por un badajo. Fue realizada esta miniatura por la tercera mano que intervino en el códice, en la que se aprecian influencias occidentales. 


\subsubsection{Las burlas a Cristo en el pretorio}

Si las diversas facetas relacionadas con la música de la vida del rey David fue el tema fundamental que aprovecharon los artistas para incluir instrumentos musicales y danzas durante los períodos Macedonio y Comneno, las burlas que recibió Cristo por parte de los soldados y judíos en el pretorio será el tema estrella de la siguiente etapa, la de los Paleólogos.

Después de varios siglos en los que la representación de los instrumentos musicales estuvo oculta a los ojos de los fieles en los folios de los códices, fue a finales del siglo XIII ${ }^{122}$ cuando su presencia comienza a notarse dentro de este tema de la Pasión, que se exhibirá ahora en las paredes, bóvedas y exonártex de las iglesias, no de Constantinopla claro está, sino de todas aquellas regiones que pertenecieron al imperio y que, como ya dijimos, se fueron separando de él por causas bélicas o políticas. Es, pues, durante los siglos XIV y XV cuando nos vamos a encontrar con muchas pinturas de esta temática en las que hacen su aparición variados instrumentos musicales, temática que, en todas estas áreas de los países balcánicos, primordialmente, se seguirá cultivando hasta bien entrado el siglo XVIII, e incluso el XIX.

Al ser tan relevante esta iconografía musical, convertida en un auténtico paradigma en este período, muchos investigadores de países que estuvieron bajo la órbita de Bizancio, como Serbia, Macedonia, Bulgaria o Rumanía ${ }^{123}$, emprendieron estudios sobre los mismos ${ }^{124}$, quedando esta parcela de la iconografía musical bizantina bastante trabajada, por lo que nosotros no vamos a entrar en ella. Tan solo queremos mostrar un ejemplo, una única pintura que complete el panorama de temas con música tratados por los artistas bizantinos en los diez siglos de historia del imperio. Hemos seleccionado un paramento de las pinturas al fresco de la iglesia de San Jorge, en Staro Nagoricane (República de Macedonia), fechada en 1317-18 (lám. 57).

Aquí, con un colorido brillante, este tema humillante y doloroso de la Pasión de Cristo se convierte en una fiesta, en la que los instrumentos musicales y danzarines son sus protagonistas. Dos largas trompas en la zona superior anuncian el acontecimiento como si fuera algo digno de ser proclamado, mientras que el grupo instrumental se encuentra a la izquierda de la composición presidido por un gran tambor cilíndrico con amarres en zigzag y un percutor de cabeza doblada, como el

122 G. ILnitchi, en "The emergence of a paradigm...», p. 47, explica en su exordium que fue en el año 1295 cuando los pintores de Tesalónica Michael Astrapas y Eutychios habían terminado las pinturas de la iglesia dedicada a la Madre de Dios en Ohrid, donde aparecía este tema al parecer por primera vez. Estos pintores trabajaron luego en la decoración de otros templos y fueron diseminando por la zona esta temática, que más tarde sería seguida a su vez por otros pintores. Desde luego, su acierto fue inmenso, dada la expansión y alcance que adquirió tanto en los Balcanes como en Italia.

${ }^{123}$ De este país, las regiones de Moldavia y Wallachia han sido estudiadas exhaustivamente por la profesora Gabriela Ilnitchi. Cfr. su catálogo de las pinturas de estas zonas en Imago Musicae, vol. XxIII, pp. 101-152.

${ }_{124}$ Cfr. los trabajos de Ion Solcanu, Roksanda Pejovic o Gabriela Ilnitchi Currie en la bibliografía adjunta. Existen también otras investigaciones que pueden verse en la nutrida bibliografía que ofrece la profesora Gabriela Ilnitchi en sus artículos para Imago Musicae. 


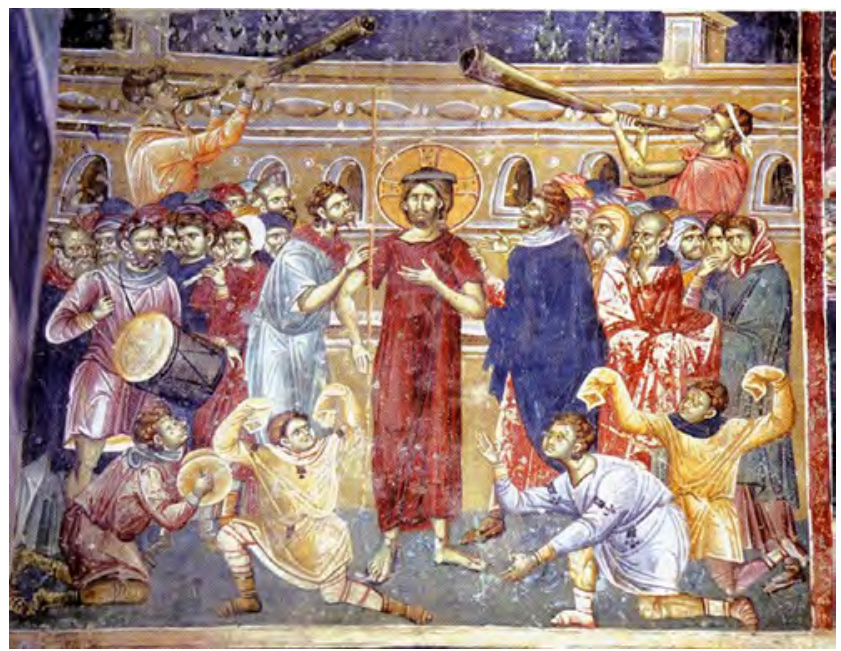

Lám. 57. Las burlas a Cristo en el pretorio. Fresco de la iglesia de San Jorge, en Staro Nagoricane (Macedonia), 1317-1318.

que ya hemos visto en anteriores imágenes. Junto a él aparece una pequeña flautilla encargada de realizar la melodía, y arrodillado en el suelo un cimbalista con platos medianos jalea con su chinchín a los que danzan con movimientos desafiantes y burlones hacia la figura de Cristo, que preside la escena, sacudiendo las largas mangas, que en manos de los hombres sustituyen a los largos velos y cintas que exhibían las mujeres en las miniaturas. Este tipo de mangas, que se prolongan mucho más allá de las manos, aparecen por primera vez en el Salterio 752 de la Biblioteca Vaticana, del año 1059, por lo que no constituye ahora ninguna novedad.

\subsection{El Ámbito PROFANO}

\subsubsection{Proclamación de un basileus}

Esta ceremonia fastuosa que tanta importancia tuvo en el ceremonial de palacio a lo largo de tantos siglos, en los que los soberanos se sucedían, a veces de forma muy rápida a causa de intrigas y asesinatos, no quedó plasmada en imágenes; en términos periodísticos actuales diríamos que no hubo ningún reportaje gráfico. Por tanto, el que uno de los miniaturistas del famoso códice que contiene una de las copias de la crónica del Juan Skylitzes, datada en el siglo xII, pintara la proclamación y coronación de un basileus en un lugar indefinido es para nosotros de suma importancia (fol. $10 \mathrm{v} .{ }^{\circ}$ ) por la presencia de instrumentos heráldicos. Se trata de la proclamación y coronación de Miguel I Rangabés como basileus por el patriarca Nikephoros, el primero revestido con las insignias imperiales y el segundo con las de su dignidad, mientras ambos son levantados sobre un escudo grande sostenido por cuatro hombres (lám. 58). 


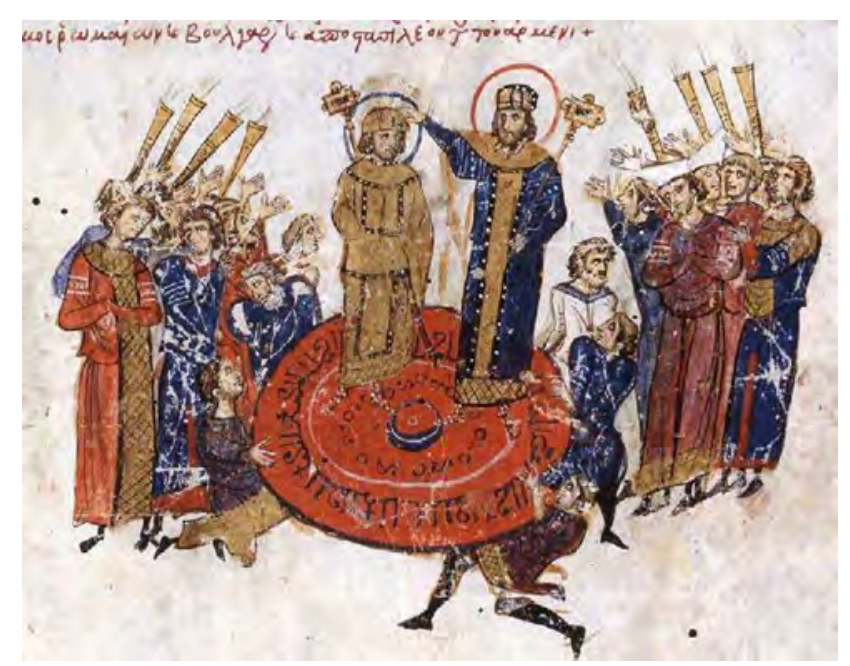

Lám. 58. Crónica de Juan Skylitzes, Bib. Nac. Madrid, 26-2, siglo XII, fol. 10v. ${ }^{\circ}$. Proclamación de un emperador.

Se sabe que fue Juliano el Apóstata (segundo tercio del siglo iv) el primer emperador romano al que su ejército proclamó por medio del rito de alzarlo sobre el escudo, costumbre bárbara que adoptaron sus tropas acantonadas en París. Como se comprueba en el Skylitzes varios siglos después, los emperadores bizantinos seguían manteniendo esta costumbre, o al menos el miniaturista la contempla en su obra por conocerla. Y de esta manera, ha dispuesto también grupos convencionales de senadores y jefes del ejército a ambos lados del escudo proclamando al emperador con las manos en alto, mientras algunos tocan trompetas rectas de tubo cónico, la antigua tuba romana, adornadas con líneas paralelas de trecho en trecho. La introducción de estos instrumentos heráldicos constituye una novedad en este tipo de escenas, pues en otra similar plasmada en el mismo códice (fol. 230r. ${ }^{\circ}$ ), en la que se proclama basileus al general armenio León Tornikios en 1047, no aparecen, ni tampoco en todas aquellas que se consideran sus precedentes ${ }^{125}$, por lo que la imagen citada resulta singular y le confiere una mayor solemnidad y prestancia al acto, al imaginarse uno mientras la contempla la potencia sonora emitida por las ocho trompetas de la miniatura tocando al mismo tiempo. El miniaturista ha tenido la curiosidad de dibujar por medio de líneas paralelas grises la emisión del aire saliendo por los pabellones, peculiaridad que se puede ver en otras miniaturas occidentales.

125 K. Weitzmann, en El rollo y el códice. Un estudio del origen y el método de la iluminación de textos, pp. 131-132, piensa que esta composición tuvo su origen en una crónica histórica, que luego fue adoptada por el Libro de los Reyes, donde vino a sustituir al tema de la unción o bien se unió a él. Varios ejemplos visuales vienen recogidos en R. Álvarez, «Incidencia de una forma de trabajo...», pp. 66 y 67. 


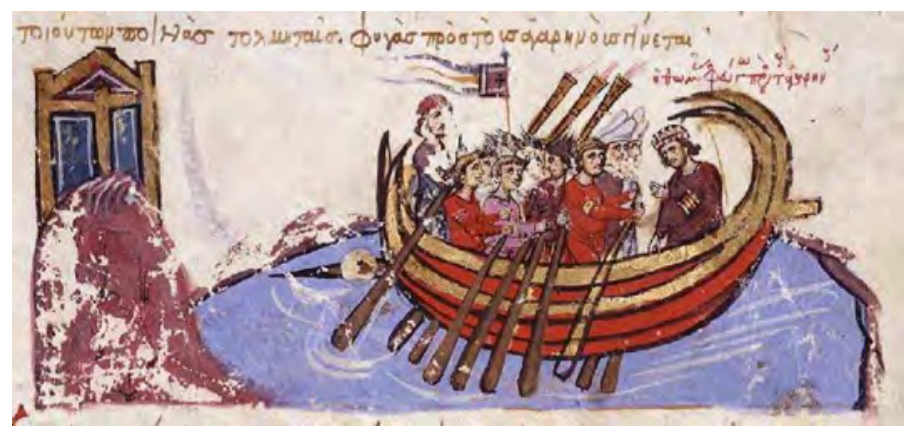

Lám. 59. Crónica de Juan Skylitzes, Bib. Nac. Madrid, 26-2, siglo XII, fol. 29v. ${ }^{\circ}$. Huida del traidor Tomás.

\subsubsection{Viajes por mar en las naves reales}

El mismo tipo de aerófono heráldico es utilizado en los traslados por mar del emperador y su familia. Tenemos en el propio códice Skylitzes dos ejemplos de ellos. Uno es en el folio $44 \mathrm{v}^{\circ}$ y otro en el $29 \mathrm{v}^{\circ}$. En el primer caso se narra un episodio en el que el emperador Teófilo se acerca a la nave de su esposa la emperatriz Theodora (será la que acabe con la iconoclastia a la muerte de su marido en el 843), muy disgustado por ver el magnífico navío del que esta disponía y que él ignoraba ${ }^{126}$. En él iban las mencionadas trompetas para marcar los tiempos de la navegación y anunciar la grandeza del personaje que iba en ella. La miniatura tiene grandes pérdidas de pintura, pero aun así se ven perfectamente los aerófonos, que en este caso son seis, muchos para ser albergados en una nave tan pequeña como la que muestra la miniatura, que no incluimos por su deterioro.

Otra nave similar es la que aparece en el folio $29 \mathrm{v}^{\circ}{ }^{\circ}$, donde huía de Constantinopla el rebelde Tomás para escapar de las penas que le esperaban por haber organizado una sublevación en Oriente contra el emperador causando muchas muertes. En esta nave, como la persona que trasporta es de dignidad inferior, solo van tres trompetas (lám. 59) ${ }^{127}$, porque está claro que el número de aerófonos estaba relacionado con la categoría del personaje a quien sirven: son ocho los instrumentos que aclaman al emperador, seis los que lleva la emperatriz en su nave y solo tres los que van en la nave del traidor Tomás, que pese a las circunstancias adversas por las que atravesaba no quiso prescindir de ellas, como tampoco de la corona que ambicionaba. Lo acompañaban algunos personajes de alto rango, cómplices de la alta traición.

\footnotetext{
126 Traducción de S. Cirac Estopañán, Skyllitzes Matritensis. Tomo I, reproducciones y miniaturas, Barcelona-Madrid, CSIC, 1965, pp. 73.

127 Ibidem, p. 62 y ss.
} 


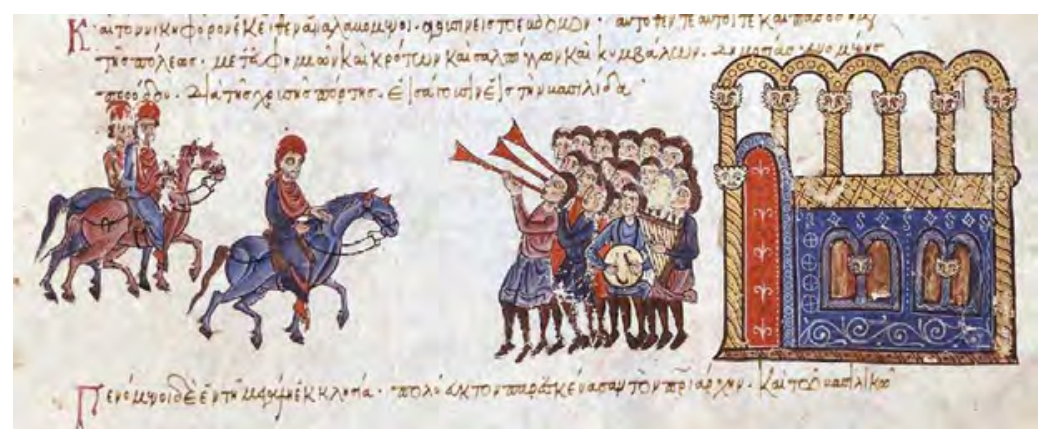

Lám. 60. Crónica de Juan Skylitzes, Bib. Nac. Madrid, 26-2, siglo XII, fol. 145 b. Entrada del emperador Nicéforo Phocas en Constantinopla.

\subsubsection{Recibimiento del emperador en una ciudad}

Sabemos por el Libro de las Ceremonias de Constantino Porfirogéneta que los desplazamientos del emperador iban acompañados por su banda de instrumentos heráldicos, algo que ni siquiera las miniaturas del códice de Juan Skylitzes, que narra todo lo concerniente a los reinados de varios basileus, desde el año 811 hasta 1057, introduce. Pero sí tenemos una pequeña muestra de la participación de la música en la llegada de un emperador a una ciudad, como sucede en el folio $145 \mathrm{~b}$, donde se describe con muy pocos medios la entrada triunfal de Nicéforo Phocas a caballo en Constantinopla, seguido de otros dos caballeros. De esta manera el miniaturista ha dispuesto delante de las puertas de la ciudad a un grupo de músicos con tres trompetas, un tambor, del que tan solo se ve su parche, y una pequeña arpa-cítara que le dan la bienvenida al monarca (lám. 60). Que estamos ante un miniaturista occidental y no procedente de Bizancio nos lo prueba la especial visión del tambor, que no muestra su perfil cilíndrico como en todas las miniaturas que ya hemos estudiado, sino solo uno de sus dos parches circulares y sus baquetas con la punta doblada. Es el especial punto de vista que tenían los artistas en Occidente, que siempre destacaban el frente de un objeto (o en este caso lo que ellos creían que era el frente) y no su perfil o su dorso, como hacían los orientales.

Por otra parte, las trompetas difieren de las vistas en otras miniaturas de este códice, que son de tubo de conicidad progresiva, como la tuba romana. Ahora en este folio están configuradas por un largo tubo, estrecho y cilíndrico, que se abre hacia su final en un pabellón acampanado, tipología indudablemente europea. Y por último, el arpa cítara presenta un modelo muy pequeño, similar al de las arpas occidentales, alejado por tanto de las arpas-cítaras bizantinas, más grandes, pesadas y graves, como las del folio $78 \mathrm{v}^{\circ}$, que veremos un poco más adelante. Pequeña banda de músicos con una combinación tímbrica muy extrańa e imposible, pues el cordófono apenas se oiría junto a las trompetas y el tambor. De todas maneras, para el tema tratado, la miniatura es muy pobre y carece de magnificencia y esplendor. 


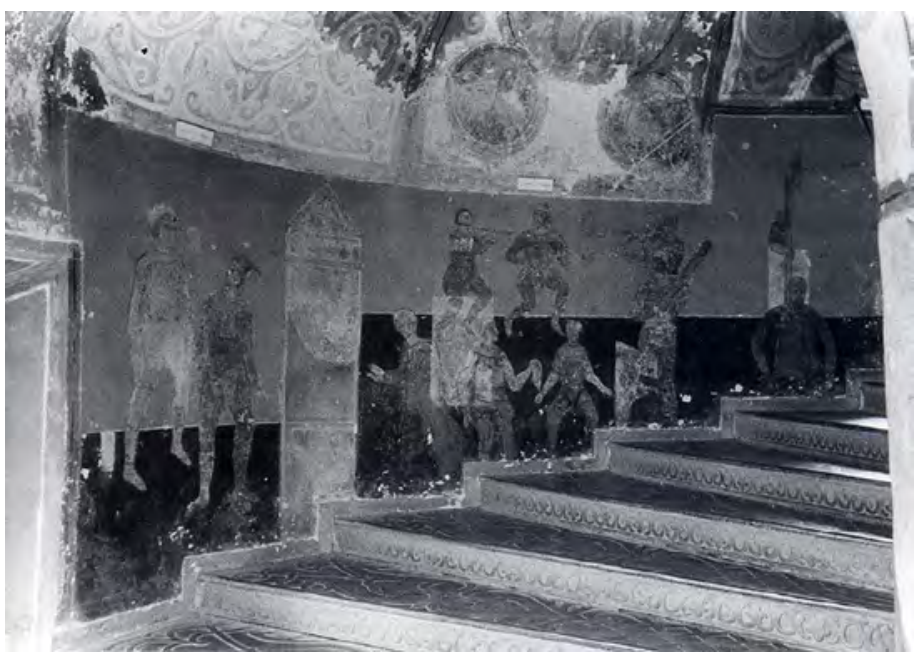

Lám. 61. Pinturas murales de la escalera de una torre. Santa Sofía de Kiev, siglo XII.

\subsubsection{De nuevo en el hipódromo de Constantinopla}

De los códices con sus miniaturas pasamos momentáneamente a las pinturas murales de la escalera que lleva a la torre suroeste de la catedral de Santa Sofía de Kiev (Ucrania), fechadas a principios del siglo XII durante el reinado de Vladimir Monomaco (1113-1125), tal y como ya hemos visto, donde se despliega una serie de músicos tocando diferentes instrumentos de las cuatro familias. Lamentablemente, estas pinturas están muy deterioradas y se ha perdido una buena parte de las mismas (lám. 61), con lo cual ha sido bastante dificultoso realizar la identificación de alguno de los instrumentos musicales allí presentes. Además, hay que tener en cuenta que las pinturas se han retocado en el pasado, posiblemente con criterios erróneos, para reponer las capas de pintura que se habían ido perdiendo con el tiempo y la humedad $^{128}$. No obstante, los investigadores rusos Irma Tockaya y Anatoly Zajaruznyi ${ }^{129}$

${ }^{128}$ A. Grabar en su artículo «Une pixide en ivoire a Dumbarton Oaks. Quelques notes sur l'art profane pendant les derniers siècles de l'empire byzantin». Dumbarton Oaks Papers, vol. 14 (1960), p. 136, nota 39 explica que estas pinturas profanas de la catedral de Kiev habían sufrido restauraciones en los años cincuenta del siglo pasado y que la serie completa de ellas se había reproducido en acuarelas en el siglo xix y se podían contemplar en Drevnosti Gosudarstva Rossijskago, Kievo-Sofijskij Sobor, publicada en ruso entre 1871-1887 en San Petersburgo. Sería cuestión de que algún investigador ruso tuviera la paciencia de ver a través de las acuarelas cómo eran en realidad estas pinturas y cómo eran los instrumentos musicales antes de ser manipuladas.

${ }^{129}$ I. Tockaja y A.M. ZaJAruZnYI, «I musici dell'affresco detto degli ‘Schomorochi' nella Cattedrale della Santa Sofia a Kiev (en ruso)». Drevne-Russkoe Iskusstvo, Mosca, 1988, pp. 143-155. 


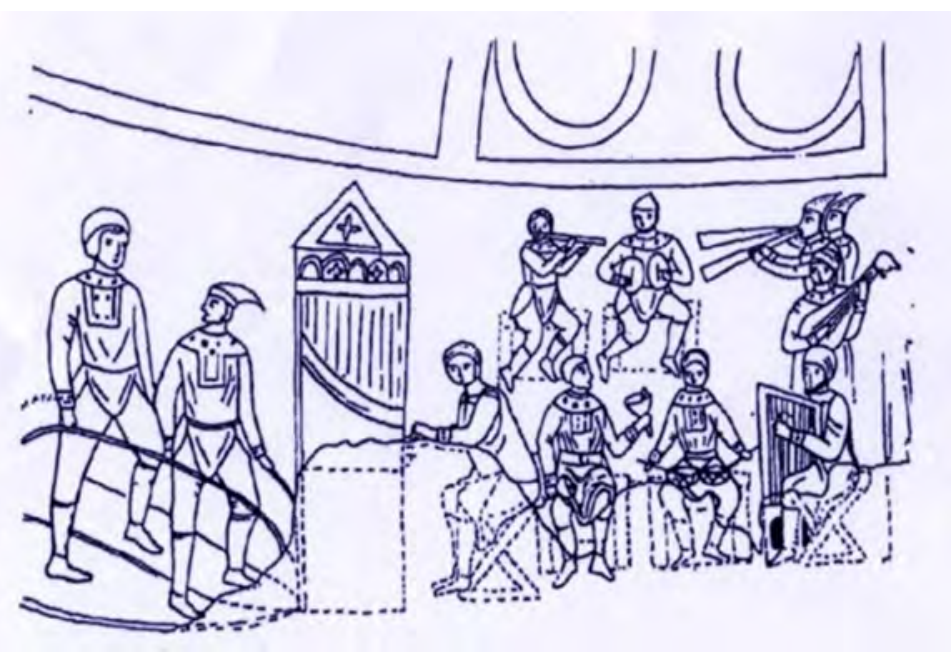

Lám. 62. Reconstrucción de los instrumentos representados en las pinturas anteriores por Tockaya y Zajaruznyi.

han podido llegar a conclusiones plausibles sobre ellos y han ofrecido un dibujo sobre su posible reconstrucción, que aquí mostramos (lám. 62).

Comenzando por la izquierda, nos encontramos con la tercera imagen que aparece en la iconografía bizantina de un órgano, de caja alta y estrecha, con cubierta a dos aguas, bajo la cual hay un tablero decorado con semicírculos y cruces. Debajo se presupone que se encuentra la tubería, indicada en el dibujo por líneas paralelas, aunque en realidad en la pintura esto no se percibe, pues supuestamente están los tubos ocultos tras una cortina. Ese cuerpo principal se apoya en un sencillo pedestal. Indudablemente, el pintor que realizó esta escena eligió la visión más sencilla del instrumento: su perfil, para evitar complicaciones en el dibujo, siendo así que las pinturas son al fresco. El organista, por su tamaño, se supone que está sentado, según estos autores en una silla de tijera, algo que puede adivinarse pero no asegurarse, y sus manos en el aire hacen ademán de manipular las tiras de madera que actúan de teclas a modo de palanca, pues en aquella época aún no se había inventado el teclado actual, que es mucho más tardío, ya del siglo xv. Detrás del órgano, y hacia la izquierda de la imagen, se encuentran dos enormes figuras de pie (su tamaño casi duplica el de los restantes músicos) que hacen de fuellistas y supuestamente están agarrados a unas barras para no caerse ante la inestabilidad que provocaba un fuelle de piel. Uno de estos personajes lleva un gorro acabado en punta, típico de los juglares de entonces, prenda que también exhiben otros músicos de este conjunto. A

Publicado en italiano en Milion. Studi e ricerche di Arte Bizantina: Arte profana e arte sacra a Bisanzio. Roma, vol. 3 (1994), pp. 281-303, fig. 29. 
la derecha del organista, se despliega un grupo de ocho instrumentistas que tañen diversos instrumentos, unos de pie y otros sentados. Los primeros, situados en el registro superior, realizan unos pasos de danza muy rítmica, a juzgar por la postura de las piernas, al mismo tiempo que tocan una flauta travesera, unos címbalos y los dos últimos unas trompetas de tubo cónico que parecen ensancharse en el pabellón. Por el contrario, los que están dispuestos en el registro inferior van sentados. Y en él vemos a un músico con una campana en la mano derecha y un pañuelo en la izquierda, aunque según la interpretación de los investigadores rusos mencionados son dos las campanas que porta, algo que nosotros no vemos, mientras que junto a él otro músico percute con baquetas de madera un par de naqqaras o timbalillos de recipiente de metal o cerámica con la cubierta de piel colocados sobre sus muslos, o eso al menos es lo que dicen los que han visto estas pinturas de cerca. Tan solo queda el rastro de uno de ellos y los brazos abiertos del músico en posición de tocar. Por su parte, el tercero puntea las cuerdas de lo que pensamos es un arpa-cítara y no una gran lira como proponen Tockaja y Zajaruznyi, sencillamente porque en esa época este cordófono de la época griega ya no se usaba y menos con las dimensiones que le han adjudicado. En cambio, sí era muy común el arpa-cítara, de la que ya hemos visto varias imágenes. Existen ejemplos en la Península Ibérica de instrumentos de este tipo, justamente en el siglo XII, que tienden hacia un contorno cuadrangular como este de aquí, pero que en la realidad no eran así. Se trataba de la especial visión del artista a la hora de dibujar el triángulo del instrumento entre las piernas del músico. Por último, entre los trompetistas y este cordófono de tabla se encuentra un músico que puntea las cuerdas de un gran laúd con mango independiente, instrumento bastante moderno para la época de estas pinturas, lo que nos hace sospechar que este fresco debió sufrir alguna intervención en el pasado y que fue adaptado, por quien la realizó, a un cordófono conocido por él y mucho más tardío, porque los instrumentos de cuerdas pulsadas en la fecha que se ha fijado para esta pintura, siglo XII, eran mucho más pequeños y con mango como prolongación de la caja. Así lo hemos visto en el Salterio Khludov, por ejemplo. La realidad es que las pinturas de Kiev carecen de calidad y la escena de perspectiva, además de ser las figuras muy desproporcionadas entre ellas, por lo que no podemos pensar que los instrumentos lo estén. Son pinturas-testimonio de la intervención de juglares en el hipódromo de Constantinopla, mientras los saltimbanquis actúan, como se puede ver más allá de este grupo, donde hay uno descendiendo por un palo. Se trata de rememorar una escena de un pasado remoto y lejano geográficamente, tomada posiblemente de dípticos consulares con instrumentos del presente.

Otro instrumento de cuerdas frotadas, una especie de lyra bizantina de caja muy alargada con mango como prolongación de la caja, finalizando en un clavijero plano y redondo, se encuentra también en otra de las pinturas murales de la escalera que da a la torre norte de esta catedral de $\operatorname{Kiev}^{130}$.

${ }^{130}$ Lo muestran tanto W. Bachmann en su libro citado The Origins of Bowing..., lám. 8, como D. Poplaswka en «String instruments in medieval Russia», fig. 10. 


\subsubsection{Escenas cortesanas y de banquetes}

Este tipo de escenas, que tan comunes son en las miniaturas y pinturas medievales del Occidente europeo en la baja Edad Media, porque muchos de los miniaturistas se convirtieron en auténticos pintores-cronistas, no las hemos encontrado en Bizancio, salvo en las miniaturas que ilustran uno de los múltiples códices del Romance de Alejandro el Grande y en menor medida en la famosa píxide de marfil del período paleólogo que se conserva en la colección Dumbarton Oaks de Washington. La historia novelada del rey macedonio que conquistó en la época helenística un vasto imperio, convirtiéndose en una auténtica leyenda, se copió, entre otros códices, en uno miniado en Trebisonda, la capital del imperio del mismo nombre, situado al sureste del mar Negro en torno a 1300. Fue la época del emperador Alejo II, en la que la región disfrutó de una gran prosperidad gracias al comercio de la seda, cuya ruta discurría entonces por estas tierras debido a una serie de circunstancias políticas y económicas. Ello contribuyó sin duda a mantener un scriptorium de lujo con buenos artífices, capaces de realizar miniaturas de una gran calidad, como es este el caso.

Ahora bien, contemplando las imágenes de este códice, que se conserva en el Instituto Griego de Venecia (codex gr. 5), percibimos la influencia de la miniatura otomana en ellas, por ese interés tan evidente hacia la representación de los acontecimientos de la corte de forma tan realista, por lo que la introducción de la música en ciertos episodios nos ofrece garantías de verosimilitud, aparte de incluir personajes con turbantes procedentes de esa otra cultura, que se entremezclan con los propiamente bizantinos, como el personaje de Alejandro, que va vestido a la usanza de los basileus. Por tanto, las páginas de este códice se apartan un tanto de las características de la miniatura de la época paleóloga, que tenía otros presupuestos estéticos y no mostraba interés por los detalles de las fiestas, los banquetes, los asuntos de la corte o la conquista de fortalezas, por ejemplo; es decir, por todo aquello que constituía entonces el mundo civil. En cambio, los diversos episodios que narra esta novela sobre la vida del gran monarca macedonio (356-323 a.C.) y las intrigas tejidas en torno suyo han dado pie a los miniaturistas, que han trabajado con una técnica en la que la témpera, el oro y la tinta sobre papel son sus medios más eficaces, a elaborar este magnífico manuscrito lleno de escenas abigarradas con múltiples figuras de distintas etnias y culturas, en las que se muestran fragmentos de lo que era la vida cortesana coetánea. En ellas se incluyen recepciones en el salón del trono y banquetes regios con comensales de alto rango, entre otras. También hay escenas de batalla que incluiremos en el epígrafe correspondiente al tema bélico.

Las que nos interesan para nuestros fines son las plasmadas en los folios $49 \mathrm{v} .^{\circ}$, 75r. ${ }^{\circ}$ y $91 r^{\circ}$. En el primero (lám. 63) y dentro de la escena de una audiencia, se ve a tres músicos, dos de ellos con turbante, tañendo una flauta recta, una trompeta bastante ridícula por su pequeño tamaño, pero con características de los añafiles musulmanes por su bola a mitad del tubo y su pabellón un tanto acampanado, y una tambura con dos únicas cuerdas que son pulsadas por el músico con los dedos. Este cordófono tiene su caja oval con tapa de piel y puntitos como adorno en ella, largo mástil y pequeño clavijero doblado hacia atrás. Salvo por este último elemento, 


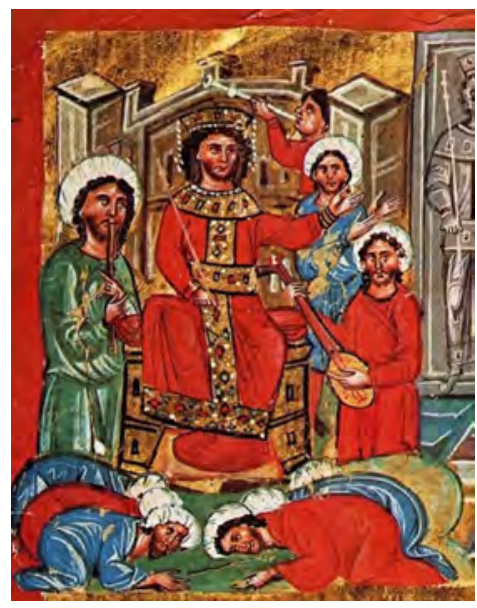

Lám. 63. Audiencia en la corte de Alejandro el Grande. Romance de este monarca, miniado en Trebisonda, ca. 1300. Instituto Griego de Venecia, cod. gr. 5, fol. 49. .

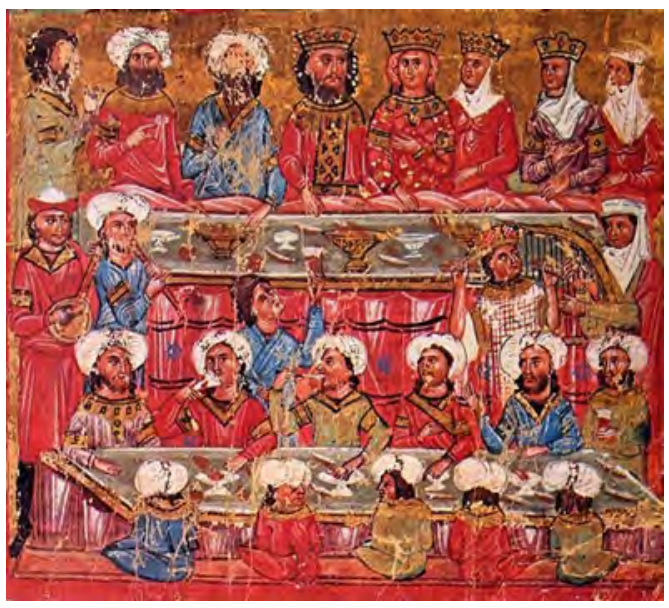

Lám. 64. Banquete del Romance de Alejandro el Grande, códice miniado en Trebisonda, $c a .1300$. Instituto Griego de Venecia, cod. gr. 5, fol. 91.r. ${ }^{\circ}$

el instrumento es exactamente igual que el plasmado en la miniatura de la cantiga 130 del códice b I 2 de las Cantigas de Alfonso X el Sabio (año 1283), conservado en la Biblioteca del monasterio de El Escorial, donde se muestran dos ejemplares iguales, en este caso con clavijeros planos en forma de hoja lanceolada. En nuestro trabajo sobre los códices alfonsinos, los hemos incluido en el apartado de instrumentos singulares, porque no existen otros ejemplos en la iconografía musical española medieval, y los hemos relacionado con los pintados en este códice de Trebisonda ${ }^{131}$, porque estaba claro que su modelo estaba en Oriente, aunque se hubiera modificado su clavijero para adaptarlo probablemente a los de las vihuelas coetáneas. En el folio $75 r^{\circ}$ y amenizando un banquete aparecen dos músicos con flauta y un pequeño laúd con caja casi circular, con tres cuerdas y clavijero doblado hacia atrás, mientras que en el folio 91r. ${ }^{\circ}$ (lám. 64), y también con motivo de un banquete donde Alejandro se encuentra acompańado por reyes occidentales ataviados a la moda occidental y por personajes turcos que van tocados con turbantes, se presentan cuatro músicos, dos

${ }^{131}$ Cfr. R. Álvarez, «Música y pintura promovidas por un sabio monarca: las imágenes musicales de los códices alfonsinos entre el testimonio de la vida musical de su corte y el pensamiento artístico de sus pintores». Ars Musica de Juan Gil de Zamora, M. PÁez Martínez (ed. y trad.), Colección Estudios Históricos de la Real Academia de Bellas Artes de Santa María de la Arrixaca, Murcia, 2009, pp. cxxiv y cxxv. 
hombres y dos mujeres, con tambura y flauta de nuevo, los primeros, y con çarparas ${ }^{132}$ o palillos entrechocados que se combinan con el chang, sang o gank, arpa persa que se trasmitió al mundo árabe a finales del siglo XII, las últimas.

Es un arpa angular abierta, con la caja de resonancia curvada, de piel normalmente, que asciende sobre las cuerdas, mientras en la parte inferior se sitúa la barra donde se anudan estas, tal y como ya hemos comentado al hablar de la miniatura del Salterio Hamilton, coetáneo de este códice. No es un instrumento muy común, aunque aparece en varias miniaturas medievales pintado en platos de la cerámica selyúcida, de los que tenemos varios ejemplos, sobre todo en aquellos que narran la historia de Bahram Gur y Azadeh, que es la que tañe el instrumento a la grupa del camello que guía su amado. Aparte de su expansión por todo el Próximo Oriente, también una imagen suya viajó a Occidente y llegó al códice español del Libro de Ajedrez, Juegos e Tablas de Alfonso X el Sabio, pulsada asimismo por una muchachita, único ejemplar de Europa y siempre en manos de mujeres.

Estos instrumentos del mundo musulmán, posiblemente otomanos, con el que tenía frontera en aquellos momentos el Imperio de Trebisonda, pasaron al mundo griego, asimilándose algunos de ellos a su propia música, como ocurre con la tambura, que hoy en día es en Grecia un cordófono importante de su música de tradición ora ${ }^{133}$. En cambio, este tipo de arpa de origen persa desapareció hacia el siglo XVII, mientras que las çarparas siguieron acompañando las danzas de mujeres en Turquía hasta el siglo XIX. Luego dejaron de usarse.

En cuanto a la iconografía musical que nos ofrece la píxide de marfil de la colección Dumbarton Oaks, hay que señalar que pese a ser un objeto tan pequeño, con un diámetro de $4,30 \mathrm{~cm}$ y una altura de tan solo $2,95 \mathrm{~cm}$, es citada por varios historiadores del arte y que, dada su relevancia, ha sido objeto de estudio por parte de dos grandes especialistas, André Grabar y Nicola Oikonomides, porque en los bajorrelieves en miniatura que envuelven frontalmente el cilindro se puede ver a dos parejas imperiales, con sus respectivos basileus, augusta y vástago de ambos. André Grabar ${ }^{134}$, el primero en ocuparse de ella, propuso las fechas de 1348-1352 e identificó a uno de ellos como Juan VI Cantacuzeno, su mujer Irene y el hijo de ambos, Mateo, mientras que la segunda pareja sería para él Juan V Paleólogo, su

132 Este es el nombre turco de los llamados en España "palillos entrechocados» o «tablillas», constituidas por dos piezas de madera alargadas y planas en sus caras interiores y ligeramente cóncavas en las exteriores para adaptarse a la mano. La iconografía tan solo muestra su perfil, y es difícil conocer cómo era en realidad cada pieza. Sin embargo, se pueden observar sus características externas en varios ejemplos, como en el techo de la capilla palatina de Palermo, en un plato turco de cerámica vidriada de la colección Alan Barlow (s. XII) y en un bronce mesopotámico del siglo XIII del Museo Victoria y Alberto de Londres. La primera imagen ibérica, la del capitel del claustro de Santa María de l' Estany, también presenta estos rasgos. Este idiófono se siguió utilizando en Turquía bajo el nombre de çarparas hasta bien adentrado el siglo XIX, siempre en manos de danzarinas. Ibidem, pp. cxix y cxx.

${ }_{133}$ Cfr. el libro de F. Anoyanakis, Greek Popular Musical Instruments. Atenas, 1979, especialmente la p. 209 y ss.

134 A. Grabar, «Une pixide en ivoire a Dumbarton Oaks», pp. 123-145. 
mujer Helena y su hijo Andrónico. Por su parte, N. Oikonomides ${ }^{135}$ retrasa las fechas de la píxide a 1403/4, e identifica a los basileus como Juan VII y Manuel II con sus respectivas familias y piensa que se hizo esta cajita para conmemorar la subida al trono de Juan VII en Tesalónica, que tuvo lugar en esas fechas. Lógicamente, nosotros no vamos a entrar en esta discusión tan antigua ni en la identificación y cronología del objeto, pero sí en la presencia y significado de esta serie de músicos y bailarinas que completan el cilindro y que reflejan la vida musical que debía practicarse en la corte. La serie de músicos comienza con un gran tambor apoyado en el suelo y percutido con baquetas rectas, del que se ve perfectamente su parche de piel y el comienzo de sus amarres, que serían probablemente en zigzag. El tambor interactúa con otro músico que sopla un aerófono cónico, posiblemente de doble lengüeta, una especie de $z a m r$ árabe, que ya vimos en el plato de plata con la boda de David y Mical (siglo viI). Dando la espalda a este dúo se encuentra una tañedora de arpa-cítara sentada, que contempla al músico que sopla una trompeta de tubo cónico, como todas las vistas en el arte bizantino, que forma pareja con otra igual situada un poco más allá. En medio de ambas aparece lo que se llama en Europa una mandora y en determinadas zonas de la Península Ibérica "guitarra morisca», es decir, un laúd corto en forma de pera, con su mástil como prolongación de la caja y su clavijero en forma de hoz rematado en talla de cabeza animal. Es la única imagen que hemos podido ver en todo el arte bizantino de esta tipología de laúd que tanta presencia tuvo en la baja Edad Media tanto en España como en otros países de Europa. El trompetista que le sigue eleva una pierna hacia atrás en el curso de una danza frenética. A continuación vemos a una mujer soplando un aerófono que ha desaparecido de sus manos, que aún conservan la postura de sostenerlo. Y finalmente se han dispuesto dos bailarinas que danzan con velos, una con los brazos en jarra y otra con ellos hacia arriba. Este conjunto es interpretado de diferente manera por los investigadores citados. Para Grabar se trata de un "divertimento del basileus», una muestra de la música cortesana que podía oírse en su palacio, mientras que para Oikonomides es la representación simbólica de los instrumentos que cita el Salmo 150, algo esto último que no suscribo. Las actitudes de los músicos son más propias de lo que solían hacer en sus actuaciones en la corte, que no simbolizando la música en alabanza al Altísimo; los trompetistas van ligeros de ropa y danzan con movimientos atléticos y con desparpajo, mientras que las danzarinas muestran también gestos atrevidos, impropios del ámbito religioso. A pesar de su pequeñez y de los imprecisas que son, estas tallas testimonian una parcela de la música profana, con la intervención de instrumentos de diferentes ámbitos: el propio bizantino (arpacítara, tambor, trompeta y aerófonos) y el del mundo árabe ‘a través ya de Europa? (laúd corto). No olvidemos que estamos ya a principios del siglo XV.

135 N. Oikonomides, "John VII Palaeologos and the Ivory Pixis at Dumbarton Oaks». Dumbarton Oaks Papers, vol. 31 (1977), pp. 329-337. 


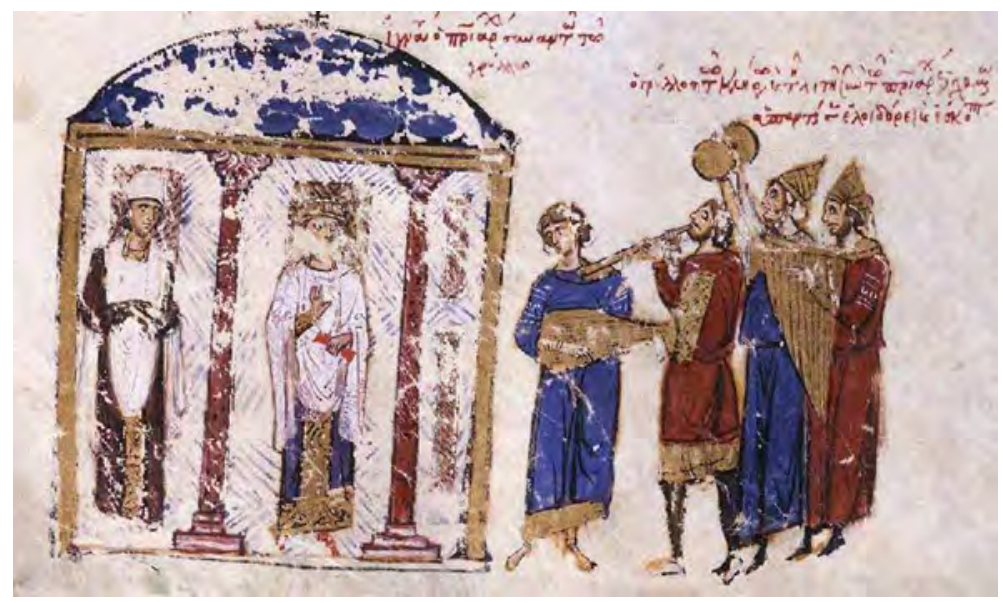

Lám. 65. Crónica de Juan Skylitzes, Bib. Nac. Madrid, 26-2, siglo xiI, fol. 78v. ${ }^{\circ}$. Las burlas al obispo Ignacio por parte de Gryllos y sus músicos.

\subsubsection{Música callejera}

Las miniaturas del códice Skylitzes (siglo XII) encierran un conjunto musical interesante en el folio $78 \mathrm{v}^{\circ}$ (lám. 65), en el que vemos cuatro músicos tañendo un arpa-cítara, unos címbalos, un largo aerófono posiblemente de doble lengüeta y un laúd de tipo árabe con el clavijero doblado en ángulo. Este grupo que dirigía un tal Gryllos fue enviado por el irreverente emperador Miguel III a una procesión para burlarse del patriarca Ignacio, que iba en ella. La crónica habla de que «este basileus había formado una compañía de trece 'citaristas' ${ }^{136}$, que se vestían con ropajes sacerdotales y parodiaban las ceremonias sagradas con acciones, cantos y música. $\mathrm{Su}$ jefe era Gryllos, al que le daban el título de "patriarca" y a los otros doce de "metropolitas". En una ocasión, Gryllos y los de su compañía se encontraron frente al patriarca, que marchaba en una procesión con otros fieles y aquéllos empezaron a tocar fuertemente sus instrumentos y a injuriar con palabras desvergonzadas a los fieles y personas piadosas que iban en ella». Es esto lo que dice la inscripción sobre sus cabezas ${ }^{137}$.

Los dos personajes de la derecha llevan trajes talares y van tocados con unos gorros en forma de mitra. Por tanto, aquí la música tiene un sentido negativo y el mezclar el laúd árabe, que en ese tiempo aún no se había incorporado a la música

${ }^{136}$ Indudablemente, se hace uso de este término por su significado genérico y de ninguna manera alude ya a las cítaras de la Antigüedad.

${ }^{137}$ Cfr. la traducción que realizó de este pasaje S. Cirac, op. cit., p. 99. 


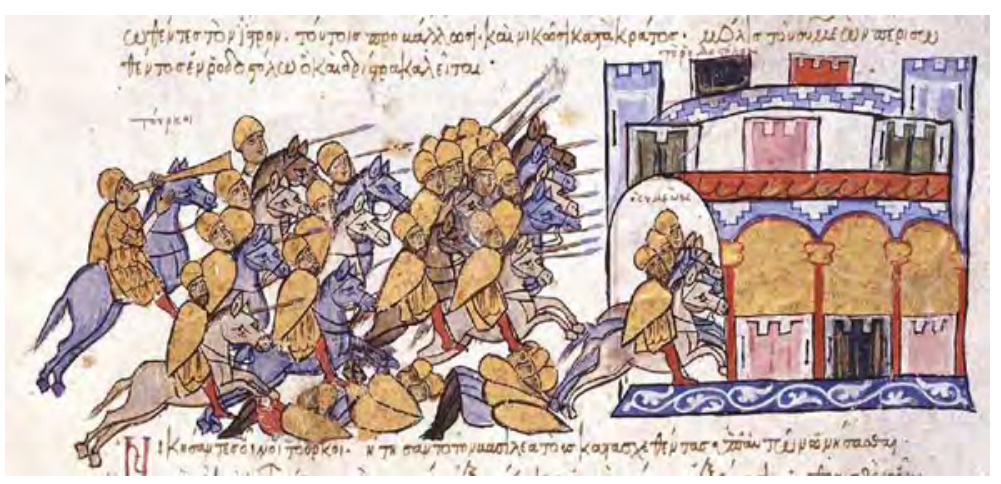

Lám. 66. Crónica de Juan Skylitzes, Bib. Nac. Madrid, 26-2, siglo XII, fol. 108v. ․ Los búlgaros vencidos por los imperiales se refugian en Dorostolón. La trompeta anuncia la victoria.

occidental por el islamismo del que estaba impregnado, con los otros instrumentos bizantinos es posible que se hiciera con el mismo propósito: herir lo más posible al patriarca, quien con toda seguridad había reprobado varias veces la conducta licenciosa y violenta de Miguel III. Quizás este tema, que estaba basado en un hecho real, contribuyó a la creación del tema de las burlas de los soldados a Cristo en el pretorio por medio de la música, un tema evangélico, cuyo texto no mencionaba la música, sino los improperios e insultos.

\subsubsection{Batallas y asedios en las Crónicas}

El último punto que debemos tratar es el de los instrumentos militares, o mejor dicho, el del único instrumento de esta categoría que nos muestran las imágenes, que es la trompeta. Este aerófono de boquilla de sonido fuerte y penetrante servía sin duda para dar órdenes a los ejércitos, enardecer los ánimos de los soldados en el curso de las batallas y dar cuenta de las victorias de alguno de los bandos. Así nos lo muestran los dos códices de las Crónicas que se conservan: la del mencionado Skylitzes matritense, fechada como ya hemos dicho en el siglo xII, y la de Constantino Manasés, más tardía, conservada en un códice húngaro de 1344-45 de la Biblioteca Vaticana, slav. 2.

El Skylitzes matritense introduce este aerófono en varias escenas de batallas, colocando al músico siempre en la retaguardia, como es lógico (fols. 107v. ${ }^{\circ}, 108 \mathrm{r} .^{\circ}$, $108 \mathrm{v} .^{\circ}, 109 \mathrm{~b}, 121 \mathrm{v}^{\circ}, 122 \mathrm{v}^{\circ}, 135 \mathrm{a}, 213 \mathrm{r} .^{\circ}, 217$ b.). Aquí mostramos el folio $108 \mathrm{v}^{\circ}{ }^{\circ}$ (lám. 66) con la derrota de los búlgaros y su huida hacia Dorostolón, mientras el trompetista da cuenta con sus toques de la señalada victoria. Otras veces este músico militar es de los enemigos y se encuentra dentro de la ciudad asediada, tocando desde una torre alejada de la zona de ataque, como en el folio $151 \mathrm{v}^{\circ}$ a, donde se recoge visualmente la toma de Mopsueste por parte de los imperiales. El mismo tipo de trompeta, pero ahora por pares, se ve en el encarnizado combate entre los 


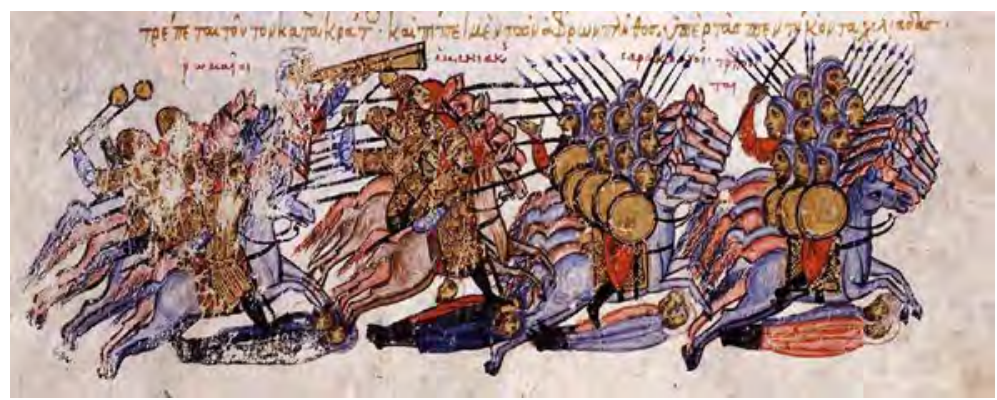

Lám. 67. Crónica de Juan Skylitzes, Bib. Nac. Madrid, 26-2, siglo xiı, fol. 213.

Los árabes perseguidos por los bizantinos en Sicilia.

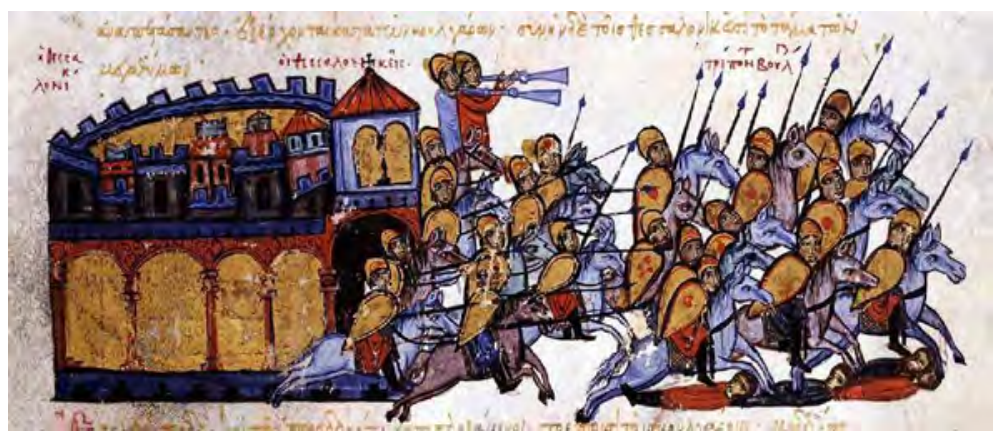

Lám. 68. Crónica de Juan Skylitzes, Bib. Nac. Madrid, 26-2, siglo xiı, fol. 217 b. Los tesalonicenses salen de la fortaleza y hacen huir a los búlgaros.

bizantinos, gobernados por Maniakés, y los árabes en Sicilia, del que el folio 213 muestra (lám. 67) a los bizantinos persiguiendo a los segundos en su huida, mientras las trompetas ensordecen el ambiente y desbaratan al enemigo. Se ven cadáveres entre las patas de los caballos y las trompetas van ahora delante del ejército vencedor.

Ahora bien, hasta aquí hemos visto un solo modelo de trompeta, pero en el folio 217 b, es decir, al final ya del códice, se introduce una tipología más moderna, influida por los instrumentos militares de los ejércitos árabes, con un tubo dividido en dos tramos: la zona cercana a la embocadura es cilíndrica y estrecha, mientras que la otra mitad es cónica, en forma de embudo. Ambos tramos están unidos por una bola, al tener que trabajarse en la fragua por separado. Podemos hablar ya de los añafiles musulmanes, que eran más ligeros y manipulables y con más posibilidades para hacer armónicos. Son estos los que nos muestran la miniatura del folio 217 b, donde los tesalonicenses hacen una salida de la fortaleza, contribuyendo así a la huida de los búlgaros al toque de dos trompetas de este nuevo modelo (lám. 68). 


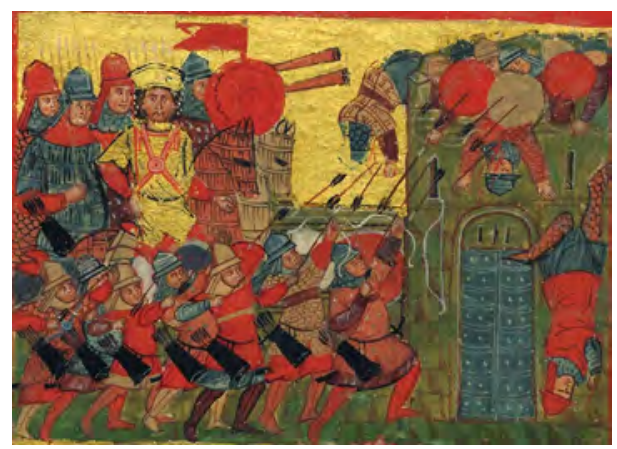

Lám. 69. Crónica de Constantino Manasés, fol. 313r. ${ }^{\circ}$. Biblioteca Vaticana, cod. slav. 2.

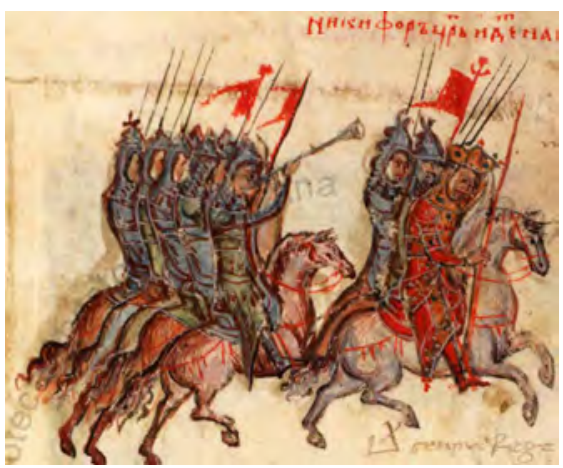

Lám. 70. Asedio de la ciudad de Atenas. Romance de Alejandro el Grande, códice miniado en Trebisonda $c a$. 1300. Instituto Griego de Venecia, cod.gr. 5, fol. 39.r. ${ }^{\circ}$.

Un añafil más moderno todavía, con un tubo largo y estrecho y pabellón terminado en forma de campana, es el que muestran las miniaturas de la Crónica de Constantino Manasés, ya a mediados del siglo xiv, en su copia de la Biblioteca Vaticana, cod. slav. 2, que se realizó en la escuela de Tarnovo. Esta copia encierra la traducción al búlgaro medieval de la crónica escrita por este cronista griego en el reinado del zar Iván Alejandro, que gobernó entre 1331 y 1371. Pues bien, en los folios 75, 101, 146, 260, 267, 296, 313, 359 y 380 de este manuscrito se encuentran grupos de guerreros con sus lanzas y entre ellas pueden verse los añafiles. Aquí mostramos la del folio 313r. ${ }^{\circ}$ (lám. 69).

Y, por último, volvemos al modelo anterior de tuba romana, con sencillos tubos de conicidad progresiva, en el folio 39r. ${ }^{\circ}$ del famoso Romance de Alejandro el Grande, de $c a$. 1300, lo que nos demuestra que los miniaturistas lo debieron copiar de algún códice y no se preocuparon por introducir los aerófonos militares de su tiempo. En esta página se nos muestra el asedio de Atenas por un Alejandro a caballo que va protegido por catafracta (lám. 70), al igual que otros caballeros que lo acompañan. Se observan tanto las tácticas de los soldados de a pie, que disparan las flechas de sus carcaj colgados al cinto, como las de los caballeros sobre sus caballos, que acompañan al estratega. Al fondo se ven dos trompetas medio ocultas por un gran escudo, que debía proteger a estos músicos militares. Mientras tanto los asediados van cayendo muertos desde los muros de la fortaleza. 


\section{ÍNDICE DE LÁMINAS}

Lám. 1. Bajorrelieve de la base del obelisco de Teodosio (año 390) en Constantinopla (actualmente Estambul). De W. Bachmann, 2004-2005, p. 192.

Lám. 2. Plato de plata del siglo viı con una ménade y Sileno. Museo del Ermitage. San Petersburgo. https://www.google.com/imgres?imgurl=http://artyx.ru/books/item/f00/s00/z0000006/ pic/000125.jpg\&imgrefurl=http://artyx.ru/books/item/f00/s00/z0000006/st019. shtml\&h=500\&w=495\&tbnid=ul_BuAOUTYk0-M\&tbnh=226\&tbnw=223\&usg= icQ_iAMkLL5Robdl4rBEAhGE6XQ=\&hl=es\&docid=9CBPMLT1jVuDvM.

Lám. 3. Díptico de marfil del cónsul Flavio Anastasio (año 517). Biblioteca Capitular de Verona. De W. BaChMANn, 2004-2005, p. 215.

Lám. 4. Mosaico de Maryamin, finales del siglo iv. Museo de Hama. https://en.wikipedia.org/wiki/ Roman_Syria\#/media/File:Mosaic_of_the_Female_Musicians.jpg.

Lám. 5. Génesis de Viena de finales del siglo v. Österrichiche Nationalbibliothek de Viena, Ms. Theol. Gr.31, fol. 17v. ${ }^{\circ}$. https://www.pinterest.fr/pin/520376931922685313/.

Lám. 6. Mosaico del Museo Arqueológico de Madaba, siglo vi. Jordania. https://www.pinterest.es/ $\operatorname{pin} / 42784265186911554 /$.

Lám. 7. Panel del díptico de Bourges, siglos v o vi. Cabinet des Medailles de la Bibliothèque National. París. https://www.pinterest.es/pin/699324648360520976/.

Lám. 8. Actriz en el teatro. Marfil del siglo vi del Staatliche Museen de Berlín. https://www.google.com/ imgres?imgurl=https://i.pinimg.com/736x/b5/31/2d/b5312de8d81325253758ce870b012bb4-ancient-music-ancient-art.jpg\&imgrefurl=https://www.pinterest.com.mx/ddimarcio/ arpas $/ \& \mathrm{~h}=967 \& \mathrm{w}=736 \& \mathrm{tbnid}=\mathrm{M6UJNrjSKVSqFM} \& \mathrm{tbnh}=257 \& \mathrm{tbnw}=196 \& \mathrm{usg}=$ HN8HT5vCPGsPFd_URQK1ftZjaz4=\&hl=es\&docid=lp8JMfSuNqdcpM\&itg=1.

Lám. 9. Marfil del siglo v con Erato entre dos filósofos. Bibliothèque de l'Arsenal n. ${ }^{\circ} 1169$. De Tilman Seebass, vol. II, p. 47.

Lám. 10. Marfil con Apolo y Dafne, siglo vi. Museo Nazionale de Rávena. https://www.pinterest. es/pin/391039180116067401/.

Lám. 11. Detalle del díptico «El Poeta y la Musa». Tesoro de la catedral de Monza, siglo vi. De F. Troncarelli, «La consolazione del dolore. Nuove ipotesi sul dittico del Poeta e della Musa». Arte medievale, núm. 1 (2010-2011), pp. 9-29, p. 10. http://www.paviaedintorni. it/temi/sguardo_nel_presente_file/curiosita\%20di\%20oggi_file/DitticodiMonza.htm.

Lám. 12. Mosaico del pavimento del peristilo del Palacio imperial de Constantinopla, siglo vi. https:// www.pinterest.es/pin/354799276867450742/.

Lám. 13. Mosaico de la basílica de Qasr Lybia. Norte de África, siglo vi. https://www.pinterest.es/ $\mathrm{pin} / 309129961908419979 /$.

Lám. 14. Églogas de Virgilio. Códice del siglo v. Biblioteca Vaticana, ms.cod.lat. 3867, fol. 44v. . http://www2.oberlin.edu/images/Art315/Art315a.html.

Lám. 15. Plato de plata del siglo viI con David y el mensajero. Museo de Chipre. Nicosia. http:// www.flickriver.com/photos/71067317@N00/8425194606/.

Lám. 16. Plato de plata del siglo vir. Museo de Chipre. Nicosia. Departamento de Antigüedades. Inv. núms. J. 452-54. https://www.pinterest.es/pin/423760646169579050/. 
Lám. 17. De Universo de Hrabanus Maurus, ms. 1896, lib. XviII, cap. IV, p. 444). Abadía de Montecasino. De R. Bragard y F. de Hen, lám. II, 12.

Lám. 18. Míriam danzando tras el Paso del Mar Rojo. Fol. 148v. ${ }^{\circ}$ del Salterio Kchludov, primera mitad del s. Ix. Museo Histórico de Moscú. https://commons.wikimedia.org/wiki/ Category:Chludov_Psalter\#/media/File:Chludov_Míriam.jpg.

Lám. 19. La danza de Míriam. Fol. 5v. el Salterio griego 139. Biblioteca Nacional de París, ca. 900. https://www.google.com/imgres?imgurl=https://2.bp.blogspot.com/-PZINTQzTzfA/ WJXiFJlKmHI/AAAAAAAAKlI/MhgAbS76yVcAgE5Yp_2cYzvK1SqiJTxQgCLcB/ s1600/005v.jpeg\&imgrefurl=http://www.newliturgicalmovement.org/2017/02/the-parispsalter.html\&h=1080\&w=978\&tbnid=5IJqTZz6d6FklM\&tbnh=236\&tbnw=214\&u sg=_SKJLodqM5M7X21n0NW0rlKuzBlc=\&hl=es\&docid=fXyKI2aDYIDwXM.

Lám. 20. Danza de Míriam con campanas rodeada de «las hijas de Israel» que tañen diversos instrumentos musicales. Salterio Barberini. Vat. gr. 372, fol. 249r. ${ }^{\circ}$. http://www.zeno.org/ Kunstwerke/B/Unbekannter+Buchmaler+des+Vatikans\%3A+Fragment+aus+dem+»Barbe rini-Psalter $«+\% 5 \mathrm{~B} 5 \% 5 \mathrm{D}$.

Lám. 21. Danza de «las hijas de Israel». Octateuco Vat. gr. 747, fol. 90v. ${ }^{\circ}$, siglo XI. https://digi.vatlib. it/view/MSS_Vat.gr.747.

Lám. 22. Danza de "las hijas de Israel». Octateuco Vat. gr. 746, fol. 194v. ${ }^{\circ}$, siglo XII. https://digi. vatlib.it/view/MSS_Vat.gr.746.pt.1.

Lám. 23. Cántico de Moisés y danza de «las hijas de Israel» Salterio Hamilton del siglo XIII, fol. 243v. ${ }^{\circ}$. Preussiches Landerbibliothek, Kupferstichkabinett 78 A 9. https://ica.princeton. edu/millet $/$ display.php? country=Germany\&site=187\&view=site\&page=4\&image $=1835$.

Lám. 24. Danza de Míriam y «las hijas de Israel». Salterio búlgaro de 1360, fol. 249v. ${ }^{\circ}$. Museo Histórico de Moscú, ms. 2752. http://www.wikiwand.com/es/M\%C3\%BAsica_cristiana.

Lám. 25. Fol. 449v. del Salterio Vat. Gr. 752, del año 1059. De Tilman Seebass, vol. II, p. 2.

Lám. 26. Placa con danzarina de la corona de oro y esmalte cloisonné del emperador Constantino IX Monomachos, siglo XI. https://www.pinterest.co.uk/pin/14003448825227923/.

Lám. 27. Rollo de Josué. Papiro bizantino de ca. 900. Bibl. Vaticana. Ms.pal. gr. 431, Seq. V. (C) https://www.google.com/imgres?imgurl=http://www.oberlin.edu/images/Art315/11584. JPG\&imgrefurl=https:/www.pinterest.com.mx/pin/401875966725734653/\&h=411\&w $=967 \&$ tbnid=HHBqK-dH5jV2KM\&tbnh=146\&tbnw=345\&usg=_IU1mV_IuMl7tGg DxYceM7nlbGTo=\&hl=es\&docid=K8aCrXmFjT1c0M\&itg=1.

Lám. 28. Octateuco de la Biblioteca Vaticana 746, pt. 2, fol. 446r. ${ }^{\circ}$. (O. https://digi.vatlib.it/view/ MSS_Vat.gr.746.pt.2'.

Lám. 29. Salterio Khludov, $1 .^{a}$ mitad del siglo Ix, fol. $147 v^{\circ}$. Museo Histórico de Moscú, col. Millet, B.1530. https://commons.wikimedia.org/wiki/Category:Chludov_Psalter\#/media/ File:Chludov_david.jpg.

Lám. 30. Salterio Khludov, 1. ${ }^{a}$ mitad del siglo Ix, fol. 2v. ${ }^{\circ}$. Museo Histórico de Moscú, col. Millet, B.1530. http://www.rodon.cz/ikony/Iluminovane-a-vzacne-rukopisy/Chludovsky-zaltar-1672.

Lám. 31. Salterio del monasterio Pantokratoros, códice 61, fol. 2r. ${ }^{\circ}$. Monte Athos. https://www. academia.edu/22401804/New_Findings_on_the_Khludov_Psalter_Revealed_during_Res-

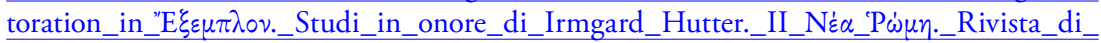


ricerche_bizantinistiche._Vol._7._Roma_Università_degli_Studi_di_Roma_Tor_Vergata_2011_pp._1_16_figs._1_23.

Lám. 32. Salterio de la Biblioteca Nacional de París, ms.139, fol. 1v. ${ }^{\circ}$. David como pastor. https:// es.wikipedia.org/wiki/Salterio_de_Par\%C3\%ADs\#/media/File:Paris_psaulter_gr139_follv. jpg.

Lám. 33. Salterio del siglo xıII. Biblioteca Vaticana, Barberini, gr. 320, fol. 2r. ${ }^{\circ}$. (․ https://digi.vatlib. it/view/MSS_Barb.gr.320.

Lám. 34. Cofre Veroli, 2. ${ }^{a}$ mitad del siglo x. Museo Victoria y Alberto de Londres. http://collections. vam.ac.uk/item/O70463/veroli-casket-casket-unknown/.

Lám. 35. Salterio de 1050. Biblioteca Vaticana, Barberini, gr. 372, fol. 5r. ${ }^{\circ}$. @. https://digi.vatlib.it/ view/MSS_Barb.gr.372.

Lám. 36. Salterio de 1050. Biblioteca Vaticana, Barberini, gr. 372, fol. 248r. ${ }^{\circ}$. (). https://digi.vatlib. it/view/MSS_Barb.gr.372.

Lám. 37. Salterio Theodore de 1066, fol. 191r. ${ }^{\circ}$. Biblioteca Británica de Londres, ms. Add. 19352. (․ http://www.bl.uk/manuscripts/Viewer.aspx?ref=add_ms_19352_f189v.

Lám. 38. Salterio Theodore de 1066, fol. 189v. ${ }^{\circ}$. David como pastor. http://www.bl.uk/manuscripts/ Viewer.aspx?ref=add_ms_19352_f189v.

Lám. 39. Códice Taphou 14 del siglo xi. Biblioteca Patriarcal de Jerusalén, fol. 33. De Anoyanakis, lám. 57.

Lám. 40. Salterio griego de 1059. Biblioteca Vaticana, gr. 752, fol. 3r. ${ }^{\circ}$ @. https://digi.vatlib.it/view/ MSS_Vat.gr.752.pt.1.

Lám. 41. Salterio griego de 1059. Biblioteca Vaticana, gr. 752, fol. 23v. ${ }^{\circ}$ C. https://digi.vatlib.it/view/ MSS_Vat.gr.752.pt.1.

Lám. 42. Vaso de vidrio (siglos IX-x) hallado en la excavación de Dvin (Armenia). De Anahit Tsisikian, p. 3.

Lám. 43. Salterio griego de 1059. Biblioteca Vaticana, gr. 752, fol. 5r. ${ }^{\circ}$ @. https://digi.vatlib.it/view/ MSS_Vat.gr.752.pt.1.

Lám. 44. Salterio griego de 1059. Biblioteca Vaticana, gr. 752, fol. 449v. ${ }^{\circ}$ C. https://digi.vatlib.it/ view/MSS_Vat.gr.752.pt.1.

Lám. 45. Salterio griego de 1059. Biblioteca Vaticana, gr. 752, fol. 7v. ${ }^{\circ}$ C. https://digi.vatlib.it/view/ MSS_Vat.gr.752.pt.1.

Lám. 46. Salterio núm. 3 del Museo Histórico de Moscú, fol. 1v.․ De Poplawska, p. 65.

Lám. 47. Salterio del monasterio de la Gran Laura del monte Athos (B 26) dek siglo XI, fol. 209v. . De Anoyanakis, lám. 109.

Lám. 48. Salterio del monasterio Stravronikita, en el monte Athos, cod. 911, del siglo XII, fol. 2v. ${ }^{\circ}$. De Anoyanakis, lám. 1.

Lám. 49. El rey David con dos de sus músicos. Códice del siglo xir. París, Bibl. Nat. Suppl. gr. 1335, fol. 258v. ${ }^{\circ}$. De Weyl Carr, lám. 49.

Lám. 50. El rey David del manuscrito Vatopedi 851, fol. 123v. ${ }^{\circ}$ del monte Athos. De Weyl Carr, lám. 50 .

Lám. 51. Detalle de la tapa de marfil del Salterio de la reina Melisenda de Jerusalén, $1 .^{a}$ mitad del siglo xII. Museo Británico, codex Egerton 1139. https:/www.pinterest.es/pin/460563499383322279/. 
Lám. 52. Salterio grecolatino Hamilton de fines del siglo xıII, fol. 41v. ${ }^{\circ}$. Berlín, Museo Estatal. David del salmo 151. https://ica.princeton.edu/millet/display.php?country=Germany\&site $=\&-$ view=country\&page $=3 \&$ image $=1749$.

Lám. 53. Homilías de san Gregorio Nacianceno, códice Taphou 14, fol. 310v. ${ }^{\circ}$. Biblioteca del Patriarca de Jerusalén. De Anoyanakis, lám. 15.

Lám. 54. Cantores en un ambón de un Evangeliario-Leccionario del monasterio Dionysiou en el monte Athos, del siglo XI, códice 587m, fol. 43. De Moran, lám. I.

Lám. 55. Salterio Tomic de ca. 1360. Museo Histórico de Moscú, fol.226. De Moran, lám. vir.

Lám. 56. Salterio Khludov, fol. 62v. ․ Primera mitad del siglo Ix. Museo Histórico de Moscú. https:// www.facsimilefinder.com/facsimiles/chludov-psalter-facsimile\#\&gid=1\&pid=7.

Lám. 57. Las burlas a Cristo en el pretorio. Fresco de la iglesia de San Jorge en Staro Nagoricane (Macedonia), 1317-18. De Gabriela Ilnitchi en Imago Musicae XxiII, fig. 23.

Lám. 58. Crónica de Juan Skylitzes, Bib. Nac. Madrid, 26-2, siglo xiI, fol. 10v. ${ }^{\circ}$. Proclamación de un emperador. http://bdh-rd.bne.es/viewer.vm?pid=d-1754254.

Lám. 59. Crónica de Juan Skylitzes, Bib. Nac. Madrid, 26-2, siglo XII, fol. 29v ${ }^{\circ}$. Huida del traidor Tomás. http://bdh-rd.bne.es/viewer.vm?pid=d-1754254.

Lám. 60. Crónica de Juan Skylitzes, Bib. Nac. Madrid, 26-2, siglo xII, fol. 145 b. Entrada del emperador Nicéforo Phocas en Constantinopla. http://bdh-rd.bne.es/viewer.vm?pid=d-1754254.

Lám. 61. Pinturas murales de la escalera de una torre. Santa Sofía de Kiev, siglo XII. De Tilman Seebass, vol. II, p. 120.

Lám. 62. Reconstrucción de los instrumentos representados en las pinturas anteriores por Tockaya y Zajaruznyi y reproducida por MAfFeI, fig. 29.

Lám. 63. Audiencia en la corte de Alejandro el Grande. Romance de este monarca, miniado en Trebisonda ca. 1300. Instituto Griego de Venecia, cod. gr. 5, fol. 49. ${ }^{\circ}$. De Anoyanakis, lám. 6.1.

Lám. 64. Banquete del Romance de Alejandro el Grande, códice miniado en Trebisonda, $c a .1300$. Instituto Griego de Venecia, cod.gr. 5, fol. 91r. ${ }^{\circ}$. De Anoyanakis, lám. 6.3.

Lám. 65. Crónica de Juan Skylitzes, Bib. Nac. Madrid, 26-2, siglo xII, fol. 78v. ${ }^{\circ}$. Las burlas al obispo Ignacio por parte de Gryllos y sus músicos. http://bdh-rd.bne.es/viewer.vm?pid=d-1754254.

Lám. 66. Crónica de Juan Skylitzes, Bib. Nac. Madrid, 26-2, siglo XII, fol. 108v. ${ }^{\circ}$ Los búlgaros vencidos por los imperiales se refugian en Dorostolón. La trompeta anuncia la victoria. http://bdh-rd.bne.es/viewer.vm?pid=d-1754254.

Lám. 67. Crónica de Juan Skylitzes, Bib. Nac. Madrid, 26-2, siglo XII, fol. 213. Los árabes perseguidos por los bizantinos en Sicilia. http://bdh-rd.bne.es/viewer.vm?pid=d-1754254.

Lám. 68. Crónica de Juan Skylitzes, Bib. Nac. Madrid, 26-2, siglo xiI, fol. 217 b. Los tesalonicenses salen de la fortaleza y hacen huir a los búlgaros. http://bdh-rd.bne.es/viewer. vm?pid=d-1754254.

Lám. 69. Crónica de Constantino Manasés, fol. 313r. ${ }^{\circ}$ Biblioteca vaticana, cod. slav. 2. https://digi. vatlib.it/view/MSS_Vat.slav.2.

Lám. 70. Asedio de la ciudad de Atenas. Romance de Alejandro el Grande, códice miniado en Trebisonda, ca.1300. Instituto Griego de Venecia, cod.gr. 5, fol. 39r. ${ }^{\circ}$. https://upload.wikimedia. org/wikipedia/commons/f/f2/Byzantine_Greek_Alexander_Manuscript_Cataphract.JPG. 


\section{BIBLIOGRAFÍA}

Álvarez Martínez, Rosario, «Presunto origen de la lira grabada en una estela funeraria (ca. s. viII a.C.) encontrada en Luna (Zaragoza)». Revista de Musicología, vol. viII, núm. 2 (1985) SEdeM, Madrid, pp. 207-228.

Álvarez Martínez, Rosario, "Instrumentos bizantinos en una pintura medieval del Museo Diocesano de Palma de Mallorca», en De Musica Hispana et aliis, Miscelánea en honor al profesor Dr. José López-Calo, vol. I, Santiago de Compostela, Universidad de Santiago de Compostela, 1990, pp. 43-53.

Álvarez Martínez, Rosario, «La iconografía musical de los Beatos de los siglos x y XI y su procedencia». Anuario del Departamento de Historia y Teoría del Arte, vol. v, (1993), pp. 201-218, Universidad Autónoma de Madrid.

Álvarez Martínez, Rosario, «El arpa-cítara (rota): su probable origen bizantino y su trayectoria mediterránea hacia la Europa occidental». Revista de Musicología, vol. xxıI, núm. 1 (1999), pp. 11-48, Madrid, SEdeM.

Álvarez Martínez, Rosario, «Iconografía de la 'guitarra' medieval, su origen centroasiático y su derivados europeos", en El sonido de la piedra. Actas del Encuentro sobre instrumentos en el Camino de Santiago, Xunta de Galicia, Santiago de Compostela, 2005, pp. 223-280 + 64 láms.

Álvarez Martínez, Rosario, "Incidencia de una forma de trabajo en la representación de los instrumentos musicales: la copia de códices en la Edad Media». Nassarre. Revista aragonesa de musicología, vol. 23, núm. 1 (2007), pp. 53-86.

Álvarez Martínez, Rosario, «Música y pintura promovidas por un sabio monarca: las imágenes musicales de los códices alfonsinos entre el testimonio de la vida musical de su corte y el pensamiento artístico de sus pintores», en Ars Musica de Juan Gil de Zamora, edición crítica y traducción española de Martín Páez Martínez, Murcia, Colección Estudios Históricos de la Real Academia de Bellas Artes de Santa María de la Arrixaca, 2010, pp. LIII-CXLIX.

Álvarez Martínez, Rosario, «Vestigios iconográficos de la liturgia y de la música del rito viejohispánico en los códices de Beato de Liébana», en Rosario Álvarez Martínez, Ismael Fernández de la Cuesta y Ana Llorens Martín (eds.), El canto mozárabe y su entorno. Estudios sobre la música de la liturgia viejo hispánica, Madrid, SEdeM, 2013, pp. 293-336.

Álvarez Martínez, Rosario, Ismael Fernández de la Cuesta y Ana Llorens Martín (eds.), El canto mozárabe y su entorno. Estudios sobre la música de la liturgia viejo hispánica. Madrid, SEdeM, 2013.

Anoyanakis, Fivos, «Ein Byzantisches Musikinstrument». Acta Musicologica, vol. 37 (1965), pp. 158-165.

Anoyanakis, Fivos, Greek Popular Musical Instruments. Atenas, Banco National de Grecia, 1979.

Bachmann, Werner, «Das Bizantische Musikinstrumentarium», en Anfänge der Slavischen, Bratislava, Ed. Ladislav Mokry, 1966.

Bachmann, Werner, The Origins of Bowing and the Development of Bowed Instruments up to the Thirteenth Century. Londres, Oxford University Press, 1969.

Bachmann, Werner, «Musikdarbietung im Hippodrom von Konstantinopel». Imago Musicae, vol. XXI-XXII (2004-05), Libraria Musicale Italiana, pp. 193-227.

Bragard, Roger y Ferd J. De Hen, Instrumentos de música. Barcelona, Daimon, 1973. 
Braun, Joachim, "Musical instruments in Byzantine illuminated manuscripts». Early Music, vol. viII, núm. 3 (1980), pp. 312-327, Cambridge.

Cirac Estopañán, Sebastián, Skyllitzes Matritensis. Tomo I. Reproducciones y miniaturas. BarcelonaMadrid, CSIC, 1965.

Conomos, Dimitri E. y Alexander Kazdhan, «Musical Instruments», en A.P. Kazdhan (ed.). The Oxford Dictionary of Byzantium, Oxford, Oxford University Press, 1991.

Constantin Porphirogénète, Le Livre de Cérémonies. Ed. Albert Vogt, Tomo I, libro I y II. París, Les belles lettres, 1935-40.

Curcic, Slobodan, «Some palatine aspects of the Cappella Palatina in Palermo». Dumbarton Oaks Papers, núm. 41 (1987), pp. 125-144, Washington.

Dienl, Charles, Manuel d'Art byzantine, vol. iI, París, A. Picard, 1925-1926, pp. 486 y 495.

Dobrynina, Elina, «New findings on the Khludov Psalter revealed during restoration, in E $\xi \varepsilon \mu \pi \lambda \circ v$.

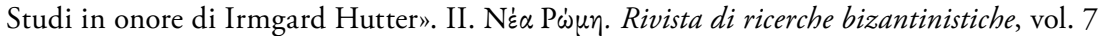
(2011), pp. 1-16, figs. 1-23, Roma, Università degli Studi di Roma «Tor Vergata».

Ducellier, Alain, Bizancio y el mundo ortodoxo. Madrid, Biblioteca Mondadori, 1992.

Farmer, Henry George, «Byzantine musical instruments in the ninth century». Journal of the Royal Asiatic Society, vol. 57, núm. 2 (1925), pp. 299-304, Londres.

Farmer, Henry George, «An early Greek Pandora». Oriental Studies, (1953), pp. 59-63, Londres.

Florea, Anca, «String instruments in Romanian mural paintings between the 14th and 19th centuries». RIdIM Newsletter, vol. 19, núm. 2 (1994), pp. 54-65.

Florea, Anca, «Wind and percussion instruments in Romanian mural painting». RIdIM Newsletter, vol. 22, núm. 1 (1997), pp. 23-30.

Gavrili-Despoti, Paraskevi, «The o sources». Imago Musicae. International Yearbook of musical iconography, vols. XXI-XXII (2004/05), Libreria Musicale Italiana, Lucca, pp. 49-65.

Grabar, André, «Les fresques des escaliers à Sainte-Sophia de Kiev et l'iconographie imperiale byzantine». Seminarium Kodakovianum, vol. viII (1935), pp. 192-197, Praga.

Grabar, André, L'empereur dans l'art byzantin. Recherches sur l'art official de l'Empire d'Orient. París, Les Belles Lettres, 1936.

Grabar, André, La peinture bizantine. Ginebra, Skira, 1953.

Grabar, André, «Une pixide en ivoire á Dumbarton Oaks. Quelques notes sur l'art profane pendant les derniers siècles de l'empire byzantin». Dumbarton Oaks Papers, vol. 14 (1960), Washington.

Grabar, André, La Edad de Oro de Justiniano. Madrid, Aguilar, 1966.

Grabar, André, Las vías de la creación en la iconografía cristiana. Madrid, Alianza forma, 2008 (1. ${ }^{\text {ed., }}$ 7. ${ }^{\mathrm{a}}$ imp.).

Gramit, David, The Music Paintings of the Cappella Palatina in Palermo. Imago Musicae, vol. II (1985). Basilea, Bärenreiter-Verlag, 1986.

Haussig, Hans Wilhem, Histoire de la Civilisation Byzantine. París, Librairie Jules Tallandier, 1971 (2. ${ }^{a}$ edición).

Ilnitchi Currie, Gabriela, "Ottoman echoes Byzantine frescoes, and musical instruments in the Balkans», en Donna A. Buchanan (ed.), Balkan Popular Culture and the Ottoman Ecumene: 
Music, Image, and Regional Political Discourse, Lanham (Maryland), The Scarecrow Press, 2007, pp. 193-224.

ILNITCHI CURRIE, Gabriela, «The emergence of a paradigm: Representations of musical instruments in the Palaiologan depinctions of the 'Mocking of Christ'». Imago Musicae, vol. XxirI (20062010), pp. 47-77, Libreria Musicale Italiana.

ILNITCHI CurRIE, Gabriela, «Catalogus: A corpus of pictorial representations of musical instruments and dances in the church frescoes of present-day Romania, Wallachia and Moldavia, ca. 1350 to ca. 1750». Imago Musicae, vol. xxIII (2006-2010), pp. 101-152, Libreria Musicale Italiana.

ILnitchi Currie, Gabriela, «Representations of musical instruments in the Byzantine and post-Byzantine iconography», en Alexandra Goulaki-Voutira (ed.), Musical Instruments in Greece from Antiquity to the Modern Era, Atenas, Universidad Aristóteles y Banco del Pireo, 2010.

Kujumdzieva, Svetlana, «A $\Sigma$ OMEN T $\Omega$ KYPI $\Omega$. The miniature depicting the Song of Moses in Manuscript Vat- Gr. 752». Music in Art, vol xxvi, núms. 1-2 (2001), pp. 93-106, Research Center for Music Iconography, New York.

LaZarev, Viktor, Old Russian Murals and Mosaics, from the XI to the XVI Century. Londres, Phaedon Press, 1966.

Levy, Kenneth, «Byzantine rite, music in the». New Grove Dictionary of Music and Musicians, Stanley Sadie, Londres, 1980, vol. 3, pp. 553-566.

Levy, Kenneth y Troelsgard, Christian, «Byzantine rite, music in the». New Grove Dictionary of Music and Musicians, Stanley Sadie, Londres, 2001, vol. 20, pp. 743-757.

Maffei, Fernanda de, «Gli strumenti musicali a Bisanzio», en Giulio Cattin (ed.), Da Bisanzio a San Marco. Musica e Liturgia, Quaderni di Musica e Storia 2, Venezia-Bologna, Fondazione Ugo e Olga Levi-il Mulino, 1997, pp. 61-110.

Maliaras, Nikos, Die orgel im byzantinische hofzerimoniell des 9. und 10. jahrhunderts. Eine Quellen Untersuchungen. Munich, Miscellanea Byzantina Monacensia, 33, 1991.

Migne, Jacques-Paul, Patrologia cursus completus. Series graeca, 16 vols., París, 1856-1866.

Moran, Neil K., Singers in Late Byzantine and Slavonic Painting. Leiden, E.J. Brill, 1986.

Oíonomides, Nicola, «John VII Palaeologos and the Ivory Pixis at Dumbarton Oaks». Dumbarton Oaks Papers, vol. 31 (1977), pp. 329-337, Washington.

Panyagua, Enrique R., «El influjo de la figura de Orfeo en la iconografía de David músico». Helmántica, vol. 45 (1994), pp. 331-338, Salamanca.

Paquette, Daniel, L'instrument de musique dans la céramique de la Grèce antique. París, Université de Lyon II. Publications de la Bibliothèque Salomon Reinach, Diffusion de Boccard, 1984.

Pejovic, Roksanda, Musical Instruments in Medieval Serbia. Belgrado, Ed. Stanojlo Rajcic, 1984.

Pejovic, Roksanda, «Folk musical instruments in Mediaeval and Renaissance art of South Slav people», en Erich Stockmann (ed.), Bericht ubre die 8. Internationale Arbeistagung der Study Group on Folk Musical Instruments des International Council for Traditional Music in Piran, Jugoslavien 1983, Estocolmo, Musikhistoriska Museet (Studia instrumentorum musicae popularis, 8), 1985, pp. 126-43.

Pejovic, Roksanda, «The mocking of Christ and other scenes from the cycle of The Sufferings of Christ as illustrated by musical instruments in Southern-European art». New sound: International magazine for music, vol. 2 (1993), pp. 71-93. 
Perrot, Jean, L'orgue. De ses origines hellénistiques à la fin du XIII siècle. París, A. Picard, 1965, pp. 308-330.

Poplawska, Dorota, «String in medieval Russia». RIdIM Newsletter, vol. 21, núm. 2 (1996), pp. 63-70.

Sas-Zaloziecky, Wladimir, «Arte bizantino». Historia del Arte universal, vol. 8, Bilbao, Moretón, 1967.

Seebass, Tilman, Musikdarstellung und Psalterillustration im früheren Mittelalter. Studien ausgehend von einer Ikonologie der handschrift París Bibliothèque Nationale fonds latin 1118. Berna, Francke Verlag, 1973.

SeEbass, Tilman, «Idee und Status der Harfe im Europäische Mittelalter». Basler Jahrbuch für Historische Musikpraxis, vol. XI (1987), pp. 139-152.

Solcanu, Ion I., «Les instruments de musique dans la peinture murale de Pays Roumains (XIV-XVII siècles)». Revue des archéologues et historiens d'art de Louvain, vol. 12 (1979), pp. 120-48.

Thibaut, Jean Baptiste, «La musique instrumentale chez les byzantins». Échos d'Orient, tomo 4, núm. 6 (1901), pp. 339-347, y tomo 5, núm. 6 (1902), pp. 343-353.

Tockaja, Irma y Zajaruznyi, Anatoly M., «I musici dell'affresco detto degli 'Schomorochi' nella Cattedrale della Santa Sofia a Kiev (en ruso)». Moscú, Drevne-Russkoe Iskusstvo, 1988. Trad. Italiana: Milion. Studi e ricerche di Arte Bizantina: Arte profana e arte sacra a Bisanzio, núm. 3 (1994), Roma.

Touliatos, Diane, «Byzantine secular music». New Grove Dictionary of Music and Musicians, Stanley Sadie, Londres, 2000, vol. 4, pp. 756-757.

Troncarelli, Fabio, «La consolazione del dolore. Nuove ipotesi sul dittico del Poeta e della Musa». Arte medievale, núm. 1 (2010-2011), pp. 9-29.

Tsitsikian, Anahit, «The earliest Armenian representations of bowed instruments». RidIM Newsletter, vol. 16, núm. 2 (1991), pp. 2-4, New York.

Vendries, Christophe, «Masculin et féminin dans la musique de la Rome antique. De la théorie musicale à la pratique instrumentale». CLIO. Histoire, Femmes et Sociétés. Musiciennes vol. 25 (2007), pp. 1-13, Presses Universitaires du Mirail. Université de Toulouse-Le Mirail.

Weitzmann, Kurt, Greek Mythology in Byzantine Art. Princeton, Princeton University Press, 1951.

Weitzmann, Kurt, El rollo y el códice. Un estudio del origen y el método de la iluminación de textos. Madrid, Nerea, 1990.

Wellesz, Egon, A History of Byzantine Music and Hymnography. Oxford, Clarendon, reimp. de la

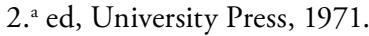

Weyl Carr, Annemarie, "A group of provincial manuscripts from the twelfth century». Dumbarton Oaks Papers, núm. 36 (1982), pp. 39-81 + 60 láms., Washington. 